\title{
Setting priorities in prevention
}

December I990

"On ne subit
pas l'avenir, on le fait."

Georges Bernanos

(La liberté, pour quoi faire? r953)

Kees Schaapveld

Ellen W. Bergsma

Jeroen K.S. van Ginneken

Harry P.A. van de Water 
Netherlands Institute for Preventive Health Care NIPG-TNO

P.O.Box 124

2300 AC Leiden

the Netherlands

Printed and published by NIPG-TNO

NIPG publication number 90.099

This report can be ordered from NIPG-TNO by tranferring $\int 40$, U.S. $\$ 25$ or equivalent (without costs to the recipient) to account number 56.70.25.500 of HGO-TNO Leiden at the Algemene Bank Nederland, Geversstraat 43, 2341 GA Oegstgeest, the Netherlands. (Within the Netherlands: giro account number of this bank is 9013).

Please state "NIPG publication number 90.099" and your name and address. Fee includes handling and mailing.

CIP data for the Royal Library, the Hague, the Netherlands:

Setting priorities in prevention / K.Schaapveld et al

Leiden: TNO Institute for Preventive Health Care

Incl. references

ISBN 90-6743-183-4

SISO 614.5 UDC 614(492)

Keywords: prevention, priorities, health policy, the Netherlands

- 1990 TNO

All rights reserved. No part of this publication may be reproduced, stored in a retrieval system, or transmitted, in any form or by any means, electronic, mechanical, photocopying, recording, or otherwise, without the prior written permission of TNO. 
1. INTRODUCTION 1

$\begin{array}{ll}\text { Literature } & 6\end{array}$

2. MEASURING HEALTH, MORBIDITY AND MORTALITY IN POPULATIONS

2.1 Introduction 7

2.2 Mortality 8

$\begin{array}{ll}2.3 \text { Life expectancy } & 12\end{array}$

2.4 Potential years of life lost 15

$\begin{array}{ll}2.5 \text { Morbidity } & 17\end{array}$

2.6 Disability-free life expectancy 22

2.7 Economic costs of morbidity and mortality 31

2.7.1 Direct and indirect costs of illness 31

$\begin{array}{ll}\text { 2.7.2 Disease costing } & 32\end{array}$

2.7.3 Disease costing in the Netherlands 36

2.8 Distribution of morbidity and mortality 42

2.8.1 Geographic variations $\quad 42$

2.8.2 Socio-economic variations 43

$\begin{array}{lll}2.9 & \text { Discussion } & 44\end{array}$

$\begin{array}{ll}\text { Literature } & 46\end{array}$

3. HEALTH BENEFITS AND COSTS OF PREVENTION 50

3.1 Introduction 50

3.2 How can gains in health be measured 51

3.3 Gains in life expactancy achieved by eliminating a cause of death 56

3.4 Models for assessing the health benefits of prevention 61

$\begin{array}{ll}3.5 & \text { Preventability of health problems } \\ \end{array}$

3.5.1 Preventability of cancer $\quad 68$

3.5.2 Preventability of cardiovascular disease 71

$\begin{array}{ll}\text { 3.5.3 Preventability of genetic and congenital diseases } & 73\end{array}$ 
3.6.1 Prevention and the costs of health care 77

3.6.2 The economic evaluation of health programmes 78

3.6.3 The economic evaluation of prevention programmes $\quad 80$

3.7 Results of the economic evaluation of prevention programmes 81

$\begin{array}{llr}\text { 3.7.1 Primary prevention } & 82\end{array}$

$\begin{array}{ll}\text { 3.7.2 Secondary prevention } & 87\end{array}$

3.8 Is a rank order based on efficiency possible for prevention programmes?

Literature

4. FUTURE DEVELOPMENTS

4.1 Introduction

4.2 Demographic projections

4.3 Epidemiological projections

4.4 Technological changes

4.5 Conclusions

Literature

5.1 Introduction

5.2 Dutch data and methods

5.3 Results

5.4 Discussion

Literature 
6. COMPETING CAUSES OF DISEASE AND DEATH 128

$\begin{array}{ll}6.1 \text { Introduction } & 128\end{array}$

$\begin{array}{ll}\text { 6.2 Demographic models } & 129\end{array}$

6.3 Results of community trials 131

$\begin{array}{ll}6.4 \text { Discussion } & 132\end{array}$

$\begin{array}{ll}\text { Literature } & 136\end{array}$

7. SUMMARY, DISCUSSION AND CONCLUSIONS 138

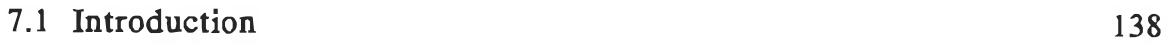

$\begin{array}{ll}\text { 7.2 Summary of foregoing chapters } & 138\end{array}$

$\begin{array}{ll}\text { 7.3 The effectiveness and the efficiency of prevention programmes } & 140\end{array}$

$\begin{array}{ll}7.4 \text { Setting priorities in prevention } & 144\end{array}$

$\begin{array}{ll}\text { 7.4.1 Methodology } & 144\end{array}$

7.4.2 An example of a rank order of prevention programmes
according to efficiency

7.5 Assessment of HFA targets and present prevention expenditure $\quad 149$

7.5.1 Health targets of WHO 149

7.5.2 The current pattern of expenditure for prevention 152

7.6 Recommendations for further research 153.

Literature $\quad 155$

APPENDIX - EUROPEAN TARGETS FOR HEALTH FOR ALL 156

$\begin{array}{ll}\text { ABBREVIATIONS } & 161\end{array}$

$\begin{array}{ll}\text { SUBJECT INDEX } & 162\end{array}$ 


\section{INTRODUCTION}

"Setting priorities in prevention" is a report commissioned by the Dutch Ministry of Welfare, Health and Cultural Affairs and prepared by the Netherlands Institute for Preventive Health Care (NIPG-TNO) in Leiden, the Netherlands. It offers a number of facts and ideas to those interested in preventive health care at the population level. It would be easy to write a complete book on the subject of each chapter and even every paragraph (for instance, on mass screening for breast cancer or the so-called "compression of morbidity"), but the purpose of this report is to combine existing knowledge about all aspects of prevention, however briefly mentioned, and to avoid the usual specific approach to isolated health problems. Review articles and editorials have therefore of ten been used, in combination with more specific articles, books and some material recently completed by NIPG-TNO. With the help of the lists of references, the reader can easily find his or her way to more specific literature. In general, the literature quoted is quite recent, having been published in 1990 or within the last few years. All references are in English, unless otherwise stated.

The report is "made in Holland" but written in English in order to invite a wide audience to participate in the debate on the possibilities and impossibilities of preventive health care. This means that although most of the tables and graphs are based on Dutch material, they always serve as an illustration of some aspect of prevention that is typical for other parts of the industrialized world. The literature quoted is as international as possible.

"Setting priorities in prevention" is one of the results of a Dutch research project called "Prevention Profiles" in analogy to terminology used in the United States of America (National Center for Health Statistics 1990). The idea behind this project was simple. Setting priorities in prevention should ideally be based on knowledge about the occurrence, socio-economic consequences and preventability of health problems, thereby taking into account possible future trends and the expected costs and benefits of preventive measures (van de Water 1986). The project was aimed primarily at improving methods used to obtain this knowledge but, in the process, useful facts and figures were also collected. It started in 1987 as a consequence of a policy change (described by de Leeuw 
1989) at the Ministry of Welfare, Health and Cultural Affairs arising from certain international developments.

In particular, in 1974, the Canadian Minister of Health, Lalonde, published "A new perspective on the health of Canadians" (Lalonde 1974; Hancock 1986) that became the basis for so-called "health policy": a shift away from the mere planning of health care services towards plans for better health. In this theoretical concept, better health can be achieved by manipulating the determinants of health, as shown in figure 1.1.

Figure 1.1 Health policy model

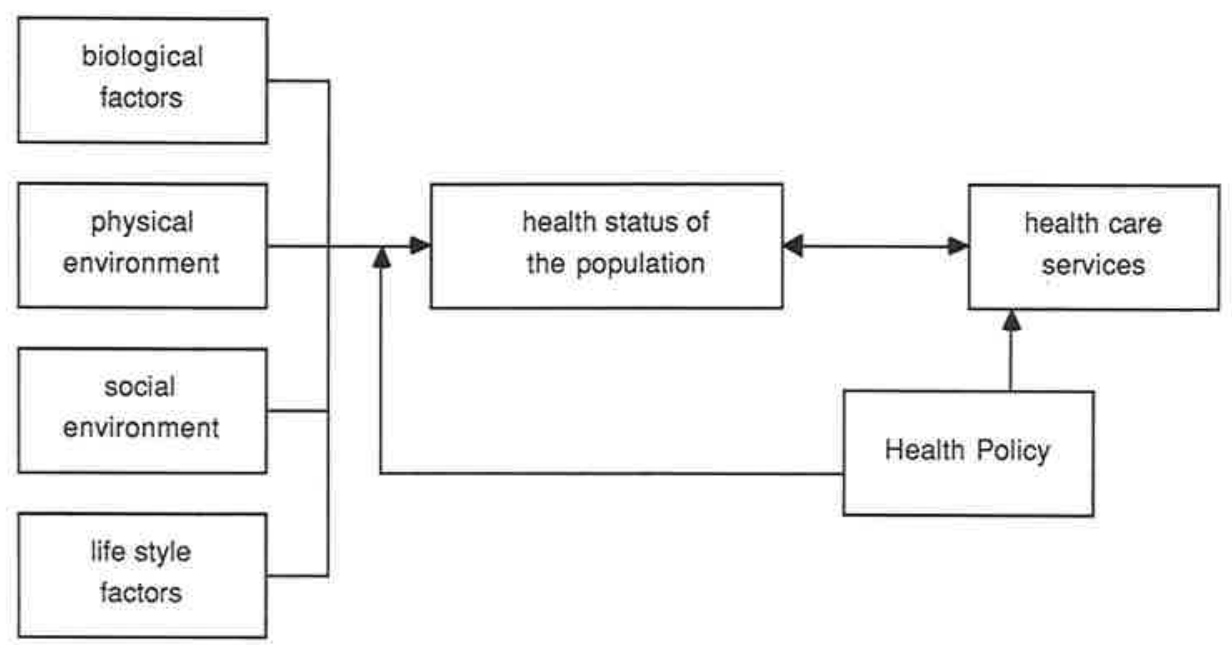

Health is determined by five groups of factors:

- biological factors, i.e. the hereditary (genetic) properties of each person;

- the physical environment, including not only air, water, soil, temperature, sound and the like, but also micro-organisms;

- the social environment, i.e. the influences of family and society on the (mental) health of a person;

- life style factors, such as smoking, nutrition, physical activity, alcohol, drugs and risk avoidance in general;

- the health care services, an important determinant which should not be neglected by focussing too heavily on preventable health problems. 
The four groups of determinants of health on the left side of the figure are the ones that lend themselves to preventive measures, although this is as yet mainly hypothetical as far as genetic factors are concerned.

Health policy places a new emphasis on prevention, although it must be kept in mind that prevention is as old as mankind and that organized preventive and social medicine dates from the end of the last century.

If health problems can be prevented, it must be possible to formulate health objectives, that is to say, what the health status of a population should be at a specified date in the future. This is what the World Health Organization (WHO) tried to do when it developed the strategy "Health for all by the year 2000". The WHO Regional Office for Europe formulated 38 health objectives (WHO 1985) that were endorsed by the European member states in 1984 (see Appendix). The new health policy and the 38 health objectives were adopted in the Netherlands in a government document called the Health Policy Memorandum 2000. An abridged version is available in English (Ministry of Welfare, Health and Cultural Affairs 1987). Other European countries have similar documents.

In order to be able to monitor progress in achieving these objectives by the year 2000 , the member states publish the values of a number of relevant health indicators every three years (Ministry of Welfare, Health and Cultural Affairs/CBS 1988; WHO 1989).

The United States "Prevention Profile" reports contain data, of ten of a quantitative nature, on many more health goals. Of the 38 European health objectives, only some have been quantified; most can be assessed only qualitatively.

Many health objectives have been established as a result of eagerness to diminish real health problems rather than on the basis of epidemiological and other types of research into the feasibility of such an undertaking. Everybody wants less cancer and less cardiovascular disease, but is this really possible and what will happen then? Will we grow older and feel healthier in the future as a result of these preventive measures? That is what this report is about. It tries to answer the questions: "What can we realistically expect of prevention, how do we measure any improvements, is it worth it, and is it possible to establish priorities for a list of prevention programmes?" The problem of the quantity and quality of the years added to life by implementing or strengthening a number of preventive 
measures is considered. Precise health objectives will not be formulated, but some of the European ones will be discussed.

It would be a sign of megalomania to think that all of this can be done in this slim report. As stated above, this is a book about ideas which, by means of examples, should stimulate discussion about the effectiveness and efficiency of prevention. It may help to formulate a more consistent health policy and more realistic health objectives and to establish priorities in prevention. The reader will see that much is still unknown in this field and that the future of ten cannot be predicted, let alone calculated. But enough is known to enable the population and their representatives to make at least some choices and let others wait.

Health policy is not a field that is reserved for a few epidemiologists and other scientists. As mentioned above, the population and their representatives at different levels of government are directly involved. This report was commissioned by the Ministry of Welfare, Health and Cultural Affairs but is intended for a wider audience that hopefully will include other public health officials, politicians, journalists, health care professionals and organizations involved in (preventive) health care. Epidemiological and other jargon has been avoided as far as possible. Back in 1938 Albert Einstein wrote in his book "The evolution of physics" that the most fundamental ideas in science are essentially simple and generally can be expressed in a language that can be understood by everyone.

In the following chapters numerous subjects will be discussed and many examples given. Relatively recent preventive measures, such as programmes directed against cardiovascular disease and cancer, are considered in more detail than "old-timers", such as control of infectious diseases by vaccination, precisely because they are recent and still have to prove their worth. Some topics have received more attention than others, not because they are more important but because recent unpublished research carried out by NIPG-TNO within the framework of the "Prevention Profiles" project has been incorporated in the text: see disability-free life expectancy, also called health expectancy ( $\S 2.6$ ), the economic costs of morbidity $(\$ 2.7)$ and gains in life expectancy by eliminating a cause of death (\$3.3). 
The report follows a step-by-step approach.

In chapter 2 the measurement of health by means of a number of indicators is described and the fact that each indicator leads to a different rank order for health problems that might be prevented is considered.

In chapter 3 the changes in health status that are expected as a result of preventive measures are discussed. Various methods are used to quantify both these changes and the costs of preventive activities directed against various health problems. This quantification should lead to still other rank orders, but the classification of health problems according to preventability is even more complicated than that based on the size of health problems.

The preventability of health problems, as described in chapter 3 , has to be seen against the background of three developments discussed in chapters 4, 5 and 6.

In chapter 4 , an overview is given of various existing reports on probable future developments relevant to health as well as preventive and curative health care technology. This chapter offers an impression of the "setting" of future preventive measures; no attempt has been made to link this information directly to the expected outcome of the prevention programmes described in chapter 3.

Chapters 5 and 6 show that gains in health might - at least in part - be offset by mechanisms that are being explored and discussed at the moment but are still far from clear. Two questions have to be answered. The first is whether the average period of (terminal) disease and disability will increase or decrease with increasing life expectancy; this is the concept of compression or decompression of morbidity. The second question is whether the partial elimination of one health problem will lead to an increase in another; this is the concept of competing causes of death and disease.

Finally, in chapter 7, a synthesis will be made of the contents of the preceding chapters, leading to some prudent conclusions about as well as recommendations for the feasibility of prevention programmes, the establishment of priorities in preventive health care and the evaluation of prevention programmes. Some of the conclusions will not startle anyone while others may be considered anything but orthodox. 


\section{LITERATURE}

EINSTEIN A, INfELd L. The evolution of physics. Cambridge: Cambridge University Press, 1938.

HANCOCK T. Lalonde and beyond: looking back at "A new perspective on the health of the Canadians". Health Promotion 1986; 1:93-100.

LALONDE M. A new perspective on the health of Canadians. Ottawa: Ministry of Mational Health and Welfare, 1974.

de LEEUY E. Health policy; an explanatory inquiry into the development of policy for the new public health in the Netherlands. Mastricht (the Netherlands): Savannah/Datawyse, 1989.

MINISTRY OF MELFARE, HEALTH AND CULTURAL AFFAIRS. Health as a focal point. The Hague: Ministerie van WVC, 1987.

MINISTRY OF WELFARE, HEALTH AND CULTURAL AFFAIRS/CBS. Health for all by the year 2000; rapportage Nederland 1988 (in Dutch). Rijswijk (the Netherlands): Ministerie van WVC, 1988.

NATIONAL CENTER FOR HEALTH STATISTICS. Heal th United States 1989 and Prevention Profile. Hyattsville, Maryland: Public Health Service, 1990; DHSS publ. no. (PHS) 90-1232.

van de HATER HPA. Ontwikkeling preventieprofielen (internal report, in Dutch). Leiden (the Netherlands): NIPG-TNO, 1986.

WHO - Regional Office for Europe. Targets for health for all: targets in support of the European regional strategy for health for all. Copenhagen: WHO, 1985.

WHO - Regional Office for Europe. Monitoring of the strategy for health for all by the year 2000; part 1, the situation in the European region, 1987/1988. Copenhagen: WHO, 1989 (doc.EUR/HST/89.1). 


\section{MEASURING HEALTH, MORBIDITY AND MORTALITY IN POPULATIONS}

\section{$2.1 \quad$ Introduction}

The health status of a population, which can be expressed in various ways, is not described in terms of health but in terms of the absence of health: morbidity and mortality.

Morbidity is a complicated phenomenon with many aspects that are sometimes difficult to quantify. Numerous health indicators that give some impression of the nature and degree of morbidity have been developed. These indicators suggest what morbidity means but cannot assess all of its dimensions.

For an in-depth discussion of the available indicators, their advantages and drawbacks and their use under various circumstances, the reader is referred elsewhere (Hansluwka 1985; Mootz 1986; Bergner and Rothman 1987; Schwefel 1987; Pelletier 1990). In this report, "objective" measures - such as mortality rates and life expectancy - are used together with "more or less objective" measures - such as incidence and prevalence rates for certain diseases, sickness absenteeism and work disability - and "subjective" measures - such as the answers obtained from health questionnaires. They will be explained as they appear in the text.

Another "objective" but indirect way of examining health and morbidity in a population is the measurement of the prevalence of known determinants of disease, such as smoking or hypercholesterolaemia.

It is possible to combine a number of health indicators into a so-called health profile of a population. A comprehensive health profile will show the areas in which the health status of the population is below standard. If (more) preventive or curative action is possible in these fields, health obiectives (health targets) can be formulated; progress towards attaining these objectives can then be evaluated by measuring the appropriate indicators. 
In order to monitor progress towards achieving the 38 European health objectives of the WHO, a number of health indicators are routinely measured in the Netherlands. The results are published every three years (Ministry of Welfare, Health and Cultural Affairs 1988).

Similar systems of formulated health objectives and an assessment and evaluation process are operational in other European countries and the United States (McGinnis 1982; Zwick 1983; McGinnis 1985; Breslow 1987; National Center for Health Statistics 1990).

Insofar as health profiles lead to preventive action against determinants of illhealth, this process can be called a prevention profile. Therefore, a prevention profile is the combined process of:

a) preparing a health profile with the help of health indicators;

b) selecting those preventive measures that offer the most effective and efficient means of reducing ill-health;

c) formulating health objectives;

d) implementing these activities;

e) evaluating whether the health objectives are being achieved.

Sometimes, the selection of preventive measures (b) is done after the formulation of health objectives (c).

If one wants to compare health indicators from different periods, regions or countries, the population groups involved must be adjusted so that they have similar sex and age distributions; this sometimes also applies for other variables such as socio-economic status. This process is called adjustment (for age, etc.). For a full discussion of this subject, the reader is referred to textbooks on epidemiology and biostatistics.

The various health indicators will be described in the remainder of this chapter.

\subsection{Mortality}

"Toute civilisation est hantée, visiblement ou invisiblement, par ce qu'elle pense de la mort." (André Malraux, in: Antimémoires, 1967) 
The (crude) mortality rate or death rate is the number of deaths in a certain year per 1,000 (or 100,000) persons of the general population. The (crude) mortality rate can be adjusted for age and sex, as described above. The mortality rate can also be given as a specific rate, e.g. for men and women, certain age groups or a specific cause of death.

It may seem paradoxical to use death as an indicator of health, but mortality rates have some advantages. They are the most objective measurement, they have been registered continuously since the last century, and they can be transformed into more appealing indicators such as life expectancy and potential years of life lost due to premature death or gained by prevention (see $\S 2.3$ and 2.4).

The disadvantage of using only mortality rates as an indicator of health is that the importance of premature deaths is underestimated; moreover the degree to which chronic, non-fatal diseases and handicaps affect one's sense of well-being cannot be taken into account.

Figure 2.1 Crude and age-adjusted death rates per 1000 for the male and female population, respectively (adjusted to the 1960 Dutch average male and female popu(ation).

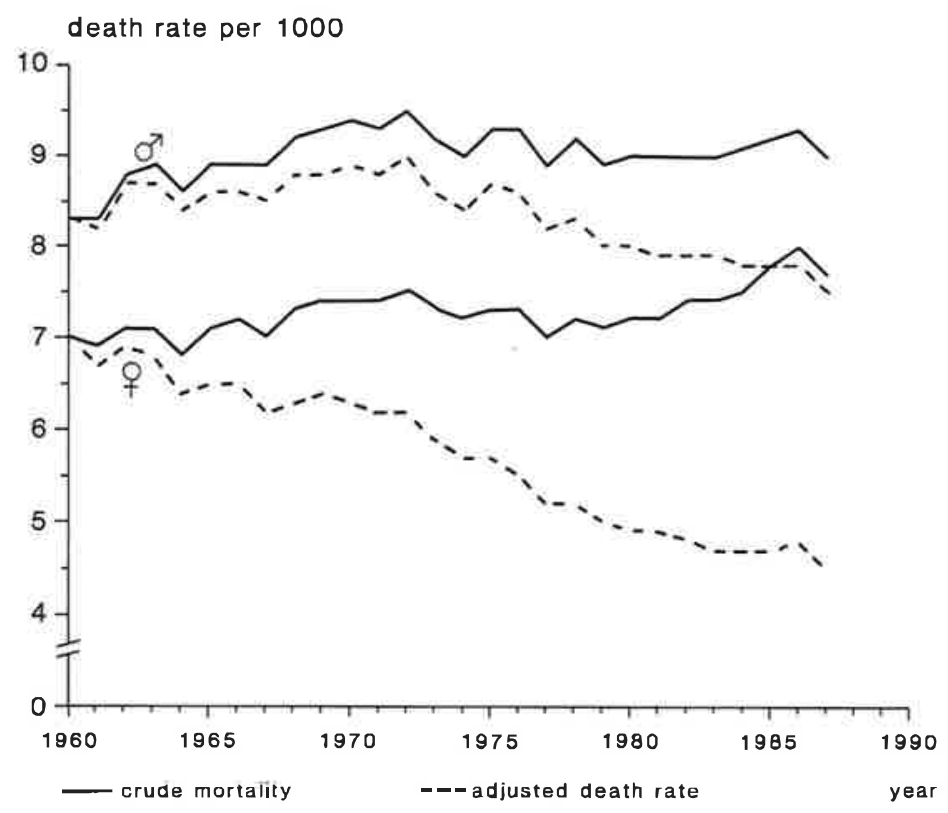

Source: CBS 1989 

Fiqure 2.2 Trends in age-adjusted total mortality rates of six European countries,
$1970-1988$

mortality rate per 100,000

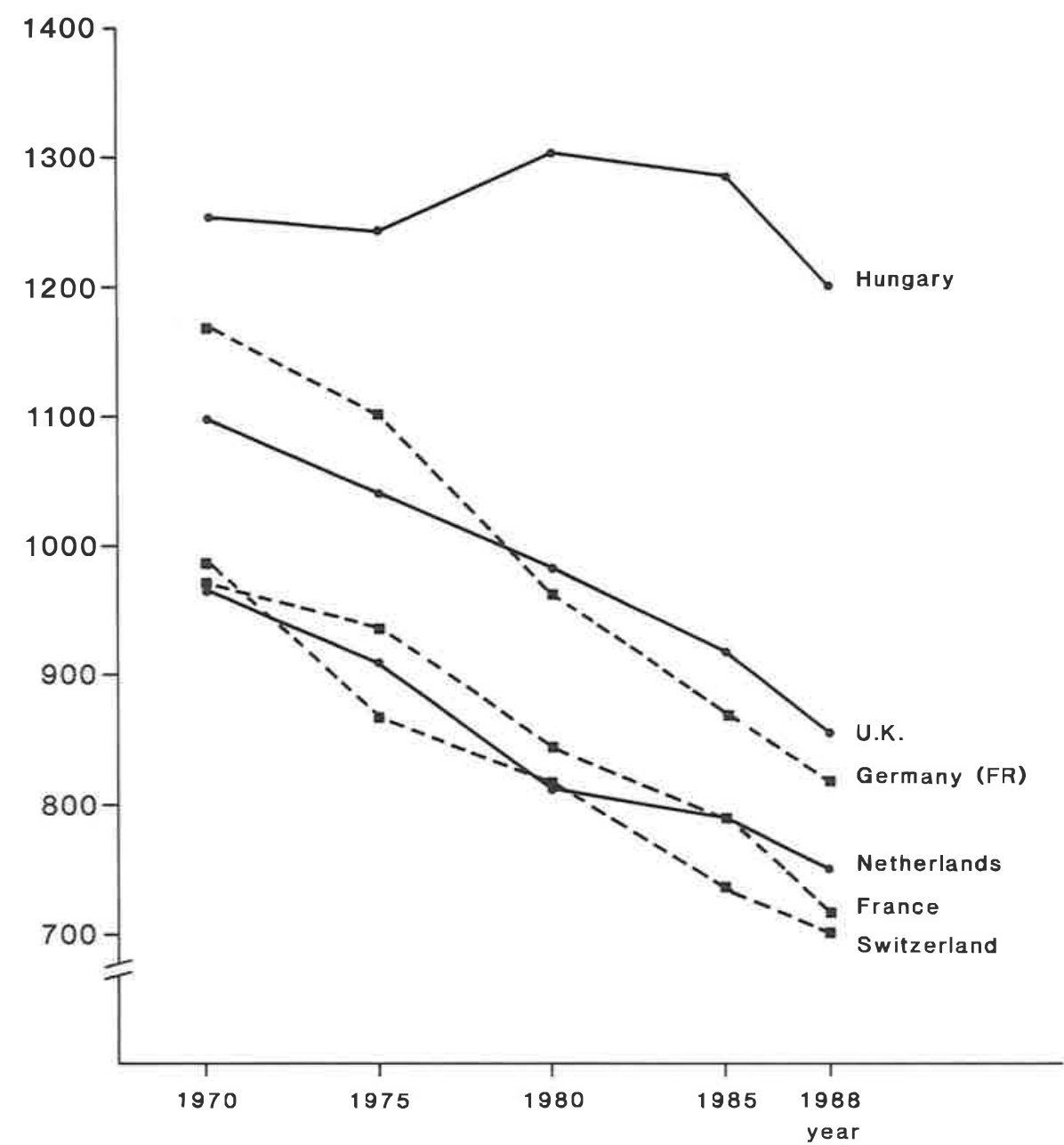

Source: Health for All Databese, HHO, Copenhagen

In figure 2.1, crude and age-adjusted mortality rates for the male and female Dutch population are shown for the period 1960-1987. There was a continuous decrease in age-adjusted mortality during the entire period for women, and since the peak of the epidemic of myocardial infarctions in 1972 for men. 
In figure 2.2, a comparison is made between the age-adjusted total mortality rates for some European countries for the period 1970-1988.

Crude and adjusted death rates for Dutch men and women for the main causes of death are shown in figure 2.3. There is a difference in the trend with time between cancer and cardiovascular diseases and between men and women.

Figure 2.3 Crude and age-adjusted mortality rates according to cause of death and sex per 100,000 for the male and female population, respectively (adjusted to the 1960 Dutch average male and female population)

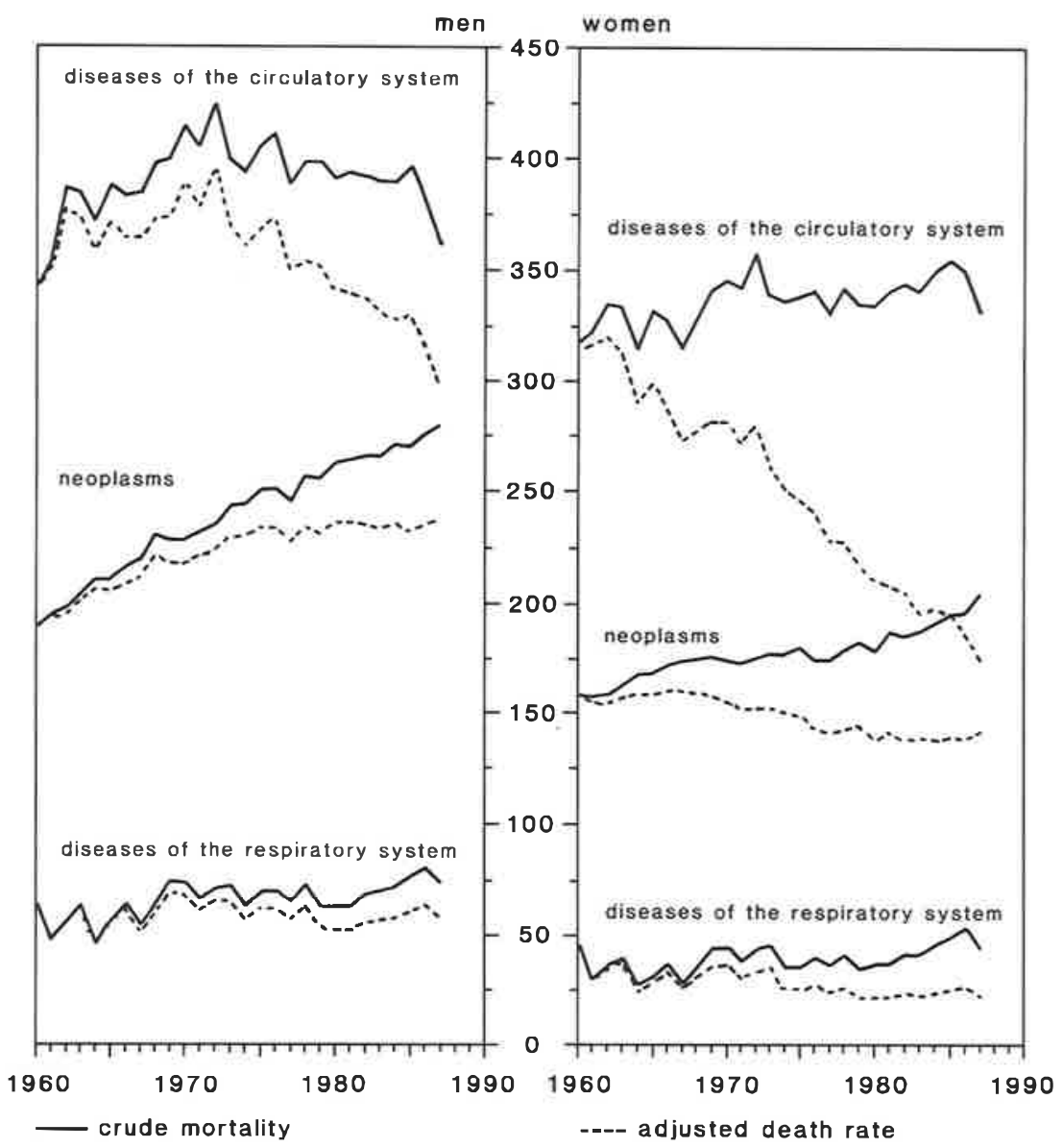

Source: CBS 1989 
In table 2.1 it can be seen that age-specific mortality rates peak at different ages for different causes of death. Death due to injuries and poisoning occurs on the average at much earlier ages than that from cancer (middle age) and cardiovascular disease (old age).

Table 2.1 Percentage distribution of deaths according to cause of death and age group, the Netherlands, 1981-1985

\begin{tabular}{|c|c|c|c|c|c|c|c|}
\hline $\begin{array}{l}\text { Cause of } \\
\text { death }\end{array}$ & $\begin{array}{l}0-24 \\
\text { years }\end{array}$ & $\begin{array}{l}25-44 \\
\text { years }\end{array}$ & $\begin{array}{l}45-64 \\
\text { years }\end{array}$ & $\begin{array}{l}65-74 \\
\text { years }\end{array}$ & $\begin{array}{l}75-84 \\
\text { years }\end{array}$ & $\begin{array}{l}85 \text { years } \\
\text { and older }\end{array}$ & total \\
\hline \multicolumn{8}{|l|}{ Men } \\
\hline $\begin{array}{l}\text { neoplasms } \\
\text { diseases of the }\end{array}$ & 0.9 & 2.9 & 25.9 & 33.0 & 28.4 & 8.9 & 100.0 \\
\hline $\begin{array}{l}\text { circulatory system } \\
\text { external causes of }\end{array}$ & 0.2 & 2.1 & 20.5 & 28.2 & 32.9 & 16.1 & 100.0 \\
\hline injury and poisoning & 22.5 & 25.8 & 20.6 & 10.4 & 12.3 & 8.4 & 100.0 \\
\hline other causes & 8.5 & 4.3 & 14.5 & 21.0 & 30.8 & 20.8 & 100.0 \\
\hline total & 3.4 & 4.1 & 20.8 & 27.1 & 30.0 & 14.6 & 100.0 \\
\hline \multicolumn{8}{|l|}{ Women } \\
\hline $\begin{array}{l}\text { neoplasms } \\
\text { diseases of the }\end{array}$ & 0.9 & 4.6 & 26.0 & 24.9 & 29.3 & 14.2 & 100.0 \\
\hline $\begin{array}{l}\text { circulatory system } \\
\text { external causes of }\end{array}$ & 0.2 & 0.9 & 7.4 & 18.3 & 41.7 & 31.5 & 100.0 \\
\hline injury and poisoning & 12.2 & 14.1 & 16.0 & 12.2 & 21.0 & 24.6 & 100.0 \\
\hline other causes & 6.6 & 2.6 & 8.8 & 14.0 & 32.7 & 35.3 & 100.0 \\
\hline total & 2.4 & 2.8 & 12.8 & 18.7 & 35.5 & 27.7 & 100.0 \\
\hline
\end{tabular}

Source: van Ginneken et al 1989

More data on cause-specific death rates will be given in $\S 2.4$. For more details, the reader is referred to the overviews of the Netherlands Central Bureau of Statistics (CBS 1980; CBS 1986; CBS 1989).

\subsection{Life expectancy}

Life expectancy is the number of years an average person can expect to live at birth or at another specified age. Life expectancy in a certain year is calculated from the mortality rates over that year; for the actual calculation, the reader is referred to textbooks on demography. 
Although an appealing indicator, it should be noted that for this calculation present mortality rates are used as if they will remain unchanged in the future. For example: the life expectancy of female children born in the Netherlands in 1987 was 79.9 years. Nobody can tell whether these children will die on the average in the year 2067. This may or - more probably - may not be the case, but life expectancy does provide an accurate impression of one aspect of the present health status of the population.

Figure 2.4 Life expectancy at birth and at the age of 65 in the Netherlands, 1951-1985.

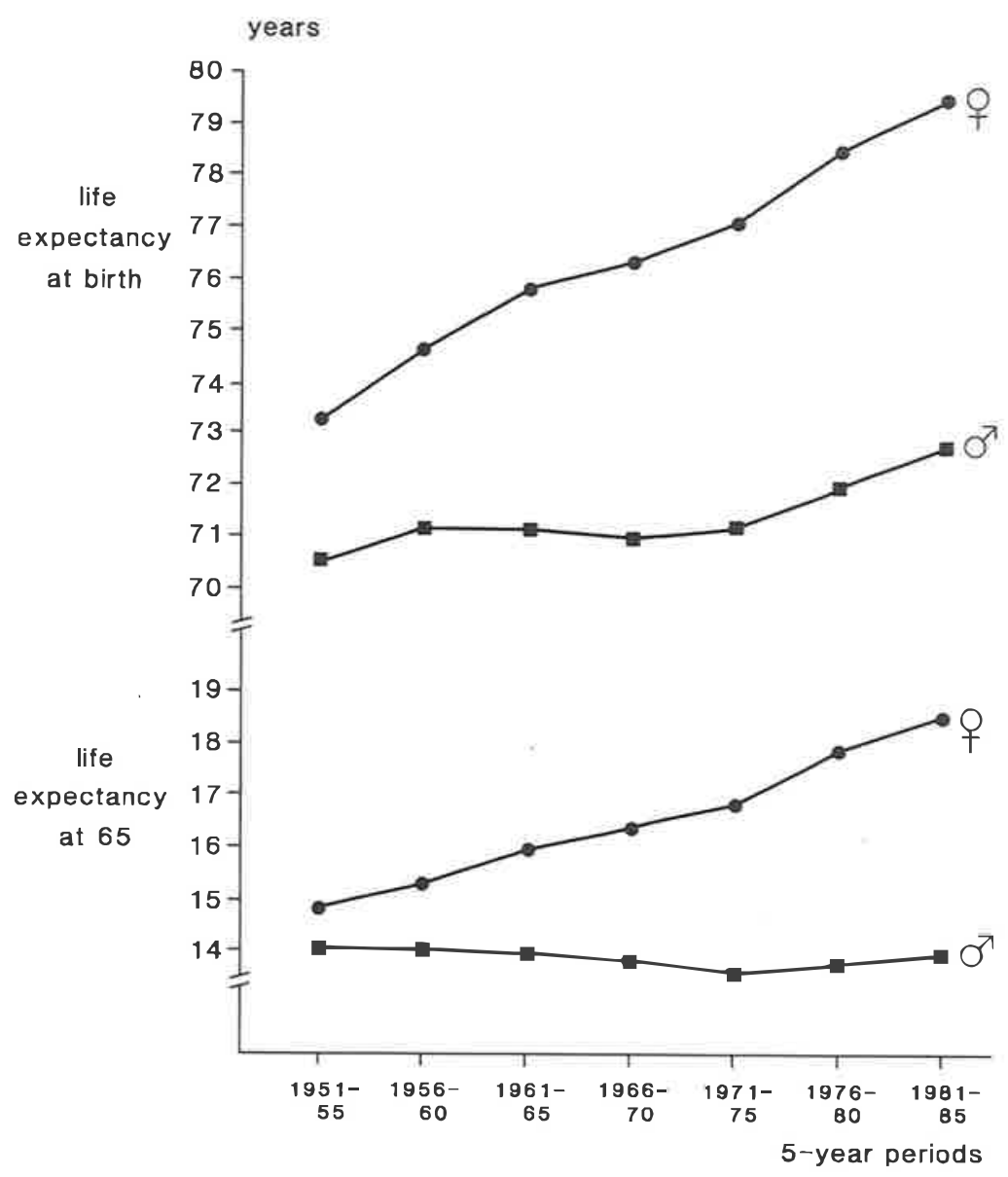

Source: CBS database 
Life expectancy can be calculated for males and females, for each age group, and for other characteristics, e.g. socio-economic status. As a rule it is given for boys and girls at birth, but for those interested in the planning of health care facilities and other aspects - such as pension plans - life expectancy at older ages is interesting as well.

In figure 2.4, recent trends in life expectancy are shown for Dutch males and females, at birth and at the age of 65, for the period 1951-1985. Female life expectancy at birth rose continuously during this period, but male life expectancy at birth increased only after 1972 when the worst of the epidemic of myocardial infarctions was over.

Female life expectancy at 65 also rose during this whole period, but male life expectancy at 65 much less and only since 1972 .

The conclusion of these graphs is that gains in male life expectancy have been made by decreasing mortality in younger age groups only, but that female mortality has been reduced in both younger and older age groups.

Some international trends in life expectancy are shown in table 2.2.

\begin{tabular}{lllll} 
Table 2.2 Life expectancy at birth (in years) & & \\
\hline Country & Men & & Women & $1980-1985$ \\
& $1950-1955$ & $1980-1985$ & $1950-1955$ & 1985 \\
\hline West Germany & 65.4 & 70.4 & 69.8 & 77.0 \\
Belgium & 65.0 & 70.2 & 70.1 & 77.5 \\
Spain & 61.6 & 71.3 & 66.3 & 78.1 \\
USA & 66.2 & 70.6 & 72.0 & 78.7 \\
France & 63.7 & 70.6 & 69.5 & 76.0 \\
Greece & 64.3 & 72.1 & 67.5 & 75.7 \\
Ireland & 65.7 & 70.4 & 68.2 & 78.0 \\
Italy & 64.3 & 71.2 & 67.8 & 79.7 \\
Japan & 62.1 & 74.3 & 65.9 & 74.0 \\
Luxembourg & 63.1 & 67.9 & 68.9 & 79.5 \\
The Netherlands & 70.9 & 72.7 & 73.4 & 75.2 \\
Portugel & 56.9 & 68.4 & 61.9 & 76.9 \\
UK & 66.7 & 70.7 & 71.8 & 79.4 \\
Sweden & 70.4 & 73.4 & 73.3 & \\
\hline
\end{tabular}

Source: United Nations. Horld Population Prospects. Estimates and Projections as assessed in 1984 (New York, United Nations, 1986) 


\subsection{Potential years of life lost}

If a person dies, one can consider the number of years between his age at death and his life expectancy at that age as potential years of life lost (PYLL). There exist variations of this definition of PYLL: for example, it is also possible to consider the number of PYLL below a fixed age of 65 or 75 . For further information the reader is referred to the references (Romeder and McWhinnie 1977; ten Hoopen et al 1982; van Ginneken et al 1989).

The concept of PYLL is an important one, because it puts more emphasis on premature death than on death at old age. An example: many more people in the Netherlands die of cancer than of traffic accidents. When using only cause-specific death rates, traffic accidents seem to be an insignificant health problem compared to cancer. However, if the number of PYLL is calculated, cancer still comes out ahead but the difference is less, since traffic deaths on the average occur at a much younger age than cancer.

Table 2.3 Percentage distribution of potential years of life lost according to cause of death and age group, the Netherlands, 1981-1985

\begin{tabular}{|c|c|c|c|c|c|c|c|}
\hline $\begin{array}{l}\text { Cause } \\
\text { of death }\end{array}$ & $\begin{array}{l}0-24 \\
\text { years }\end{array}$ & $\begin{array}{l}25-44 \\
\text { years }\end{array}$ & $\begin{array}{l}45-64 \\
\text { years }\end{array}$ & $\begin{array}{l}65-74 \\
\text { years }\end{array}$ & $\begin{array}{l}75-84 \\
\text { years }\end{array}$ & $\begin{array}{l}85 \text { years } \\
\text { and older }\end{array}$ & total \\
\hline \multicolumn{8}{|l|}{ Men } \\
\hline $\begin{array}{l}\text { neoplasms } \\
\text { diseases of the }\end{array}$ & 4.4 & B.8 & 40.2 & 29.3 & 15.3 & 2.1 & 100.0 \\
\hline $\begin{array}{l}\text { circulatory system } \\
\text { external causes of }\end{array}$ & 1.3 & 7.2 & 37.5 & 29.1 & 20.5 & 4.4 & 100.0 \\
\hline injury and poisoning & 43.1 & 34.7 & 14.9 & 3.8 & 2.7 & 0.8 & 100.0 \\
\hline other causes & 38.1 & 10.9 & 18.8 & 15.0 & 13.2 & 4.0 & 100.0 \\
\hline total & 16.6 & 11.9 & 30.8 & 22.5 & 15.0 & 3.2 & 100.0 \\
\hline \multicolumn{8}{|l|}{ Homen } \\
\hline $\begin{array}{l}\text { neoplasms } \\
\text { diseases of the }\end{array}$ & 3.9 & 12.6 & 42.1 & 23.1 & 15.7 & 2.6 & 100.0 \\
\hline $\begin{array}{l}\text { circulatory system } \\
\text { external causes of }\end{array}$ & 1.2 & 4.2 & 19.6 & 28.2 & 36.9 & 9.9 & 100.0 \\
\hline injury and poisoning & 34.9 & 28.3 & 18.6 & 7.7 & 7.4 & 3.1 & 100.0 \\
\hline other causes & 35.8 & 8.3 & 15.6 & 14.3 & 18.8 & 7.3 & 100.0 \\
\hline total & 14.0 & 9.9 & 25.5 & 21.2 & 23.0 & 6.4 & 100.0 \\
\hline
\end{tabular}

Source: van Ginneken et al 1989 
This is illustrated in tables 2.3, 2.4 and 2.5. Calculation of the figures in these tables has been described elsewhere (van Ginneken et al 1989). Here only results are given.

Table 2.4 Mortality rates and potential years of life lost for 17 ICD categories of causes of death, the Netherlands, 1981-1985 ( $M=$ mortality rate; $P=$ potential years of life lost; $R=$ rank order )

\begin{tabular}{|c|c|c|c|c|c|c|c|c|}
\hline \multirow[t]{3}{*}{ Cause of death } & \multicolumn{4}{|c|}{$\begin{array}{l}\text { Mortality rate } \\
\text { per } 100,000\end{array}$} & \multicolumn{4}{|c|}{$\begin{array}{c}\text { Potential years of } \\
\text { life lost, } \\
\text { per 100,000 }\end{array}$} \\
\hline & \multicolumn{2}{|c|}{ Men } & \multicolumn{2}{|c|}{ Women } & \multicolumn{2}{|c|}{ Men } & \multicolumn{2}{|c|}{ Women } \\
\hline & $\mathbf{M}$ & $\mathbf{R}$ & $\mathbf{M}$ & $\mathbf{R}$ & $\mathbf{P}$ & $\mathbf{R}$ & $\mathbf{P}$ & $\mathbf{R}$ \\
\hline Infectious and parasitic diseases & 4 & 12 & 4 & 13 & 72 & 12 & 70 & $12 \frac{1}{2}$ \\
\hline Neopl asms & 267 & 2 & 189 & 2 & 3315 & 2 & 2963 & 2 \\
\hline Endocrine, nutritional and metabolic & & & & & & & & \\
\hline $\begin{array}{l}\text { diseases and immunity disorders } \\
\text { Diseases of the blood and blood-forming }\end{array}$ & 12 & 9 & 19 & $\pi / 2$ & 166 & 10 & 224 & 10 \\
\hline organs & 2 & $15 \frac{1}{2}$ & 3 & $151 / 2$ & 28 & 15 & 32 & 15 \\
\hline Mental disorders & 3 & $13 \frac{1}{2}$ & 4 & 13 & 40 & 13 & 38 & 14 \\
\hline $\begin{array}{l}\text { Diseases of the nervous system and } \\
\text { sense organs }\end{array}$ & 15 & 8 & 13 & 9 & 260 & 9 & 226 & 9 \\
\hline Diseases of the circulatory system & 393 & 1 & 345 & 1 & 4153 & 1 & 3192 & 1 \\
\hline Diseases of the respiratory system & 71 & 3 & 43 & 3 & 611 & 5 & 368 & 5 \\
\hline Diseases of the digestive system & 28 & 6 & 31 & 5 & 349 & 7 & 326 & 6 \\
\hline $\begin{array}{l}\text { Diseases of the genitourinary system } \\
\text { Complications of pregnancy, childbirth }\end{array}$ & 17 & 7 & 19 & $\pi / 2$ & 118 & 11 & 147 & 11 \\
\hline $\begin{array}{l}\text { and puerperium } \\
\text { Diseases of the skin and subcutaneous }\end{array}$ & - & & 0 & 17 & - & & 8 & 17 \\
\hline tissue & 2 & $151 / 2$ & 4 & 13 & 10 & 16 & 26 & 16 \\
\hline Diseases of the musculoskeletal system & & & & & & & & \\
\hline and connective tissue & 3 & $13 \frac{1}{2}$ & 6 & 10 & 29 & 14 & 70 & $12 \frac{1}{2}$ \\
\hline Congenital anomalies & 6 & 10 & 5 & 11 & 377 & 6 & 320 & 8 \\
\hline Certain conditions originating in the & & & & & & & & \\
\hline perinatal period & 5 & 11 & 3 & $15 \frac{1}{2}$ & 335 & 8 & 247 & 7 \\
\hline Symptoms, signs and ill-defined conditions & 31 & 5 & 25 & 6 & 613 & 4 & 415 & 4 \\
\hline External causes of injury and poisoning & 49 & 4 & 33 & 4 & 1474 & 3 & 759 & 3 \\
\hline total & 907 & & 746 & & 11951 & & 9430 & \\
\hline
\end{tabular}

Source: van Ginneken et ol 1989 
Table 2.5 Mortality rates and potential years of life lost, for 20 main causes of death, the Netherlands, 1981-1985 (M = mortality rate; $P$ = potential years of life lost; $R=$ rank order)

\begin{tabular}{|c|c|c|c|c|c|c|c|c|}
\hline \multirow[t]{3}{*}{ Cause of death } & \multicolumn{4}{|c|}{$\begin{array}{l}\text { Mortality rate } \\
\text { per } 100,000\end{array}$} & \multicolumn{4}{|c|}{$\begin{array}{c}\text { Potential years of } \\
\text { life lost, } \\
\text { per } 100,000\end{array}$} \\
\hline & \multicolumn{2}{|c|}{ Men } & \multicolumn{2}{|c|}{ Women } & \multicolumn{2}{|c|}{ Men } & \multicolumn{2}{|c|}{ Women } \\
\hline & M & $\mathbf{R}$ & M & $\mathbf{R}$ & $\mathbf{P}$ & $\mathbf{R}$ & $\mathbf{P}$ & $\mathbf{R}$ \\
\hline \multicolumn{9}{|l|}{ Malignant neoplasms of the digestive } \\
\hline \multicolumn{9}{|l|}{ Malignant neoplasms of the respiratory } \\
\hline system & 106 & 2 & 12 & 16 & 1305 & 2 & 216 & 16 \\
\hline $\begin{array}{l}\text { Malignant neoplasms of bone, connective } \\
\text { tissue, skin and breast }\end{array}$ & & & & & & & & \\
\hline \multicolumn{9}{|l|}{ Malignant neoplasms of the genitourinary } \\
\hline system & 42 & 7 & 31 & $61 / 2$ & 400 & 10 & 495 & 6 \\
\hline \multicolumn{9}{|l|}{ Malignant neoplasms of lymphatic and } \\
\hline haematopoietic tissue & 18 & $11 \frac{1}{2}$ & 15 & 12 & 301 & 14 & 266 & 10 \\
\hline \multicolumn{9}{|l|}{ Endocrine, nutritional and metabolic } \\
\hline diseases and immunity disorders & 12 & 16 & 19 & $10 / 2$ & 166 & 16 & 224 & 15 \\
\hline \multicolumn{8}{|l|}{ Diseases of the nervous system and } & 14 \\
\hline Acute myocardial infarction & 174 & 1 & 110 & 1 & 2086 & 1 & 1160 & 1 \\
\hline Other ischaemic heart disease & 40 & 8 & 27 & 8 & 415 & 8 & 242 & 13 \\
\hline \multicolumn{9}{|l|}{ Diseases of the pulmonary circulation } \\
\hline and other heart diseases & 77 & 3 & 89 & 3 & 702 & 4 & 699 & 5 \\
\hline Cerebrovascular diseases & 72 & $4 \frac{1}{2}$ & 95 & 2 & 648 & 6 & 871 & 2 \\
\hline Pneumonia, bronchopneumonia and influenza & 20 & 10 & 23 & 9 & 611 & 7 & 153 & 18 \\
\hline Chronic bronchitis, emphysema and asthma & 45 & 6 & 14 & $13 \frac{1}{2}$ & 140 & 17 & 155 & 17 \\
\hline Diseases of the digestive system & 28 & 9 & 31 & $61 / 2$ & 349 & 12 & 326 & 7 \\
\hline Diseases of the genitourinary system & 17 & 13 & 19 & $10 \%$ & 118 & 18 & 147 & 19 \\
\hline Congenital anomalies & 6 & 18 & 5 & 19 & 377 & 11 & 320 & 8 \\
\hline \multicolumn{9}{|l|}{ Certain conditions originating in the } \\
\hline perinatal period & 5 & $191 / 2$ & 3 & 20 & 335 & 13 & 247 & 12 \\
\hline Traffic accidents & 18 & $11 \frac{1}{2}$ & 7 & 18 & 650 & 5 & 250 & 11 \\
\hline Accidental fall & 8 & 17 & 14 & $13 \frac{1}{2}$ & 87 & 20 & 92 & 20 \\
\hline Suicide & 14 & 15 & 9 & 17 & 401 & 9 & 273 & 9 \\
\hline
\end{tabular}

Source: van Ginneken et al 1989

\subsection{Morbidity}

According to the World Health Organization, health is "a state of complete physical, mental and social well-being and not merely the absence of disease or 
infirmity". That is all very nice, but the epidemiologist trying to describe the health status of a population can in general only analyse the presence of disease or infirmity, and even that analysis has many difficulties and pitfalls.

Indicators of morbidity in a population can be grouped together broadly as:

a incidence and prevalence rates for certain diseases

b prevalence of impairments, disabilities and handicaps

c subjective well-being and other answers to health questionnaires

d utilization of health services (doctors, hospital beds, drugs, etc.)

e sickness absenteeism and work disability

f prevalence rates for known determinants of disease.

Most of these categories overlap: certain diseases lead to impairments or disabilities, health questionnaires can yield information about incidence and prevalence, hospital admissions can provide data on the incidence of some diseases, and so on.

It is more important to discern trends in morbidity than to attach values to the various indicators at a certain moment. However, the interpretation of trends in illness and disability is hampered by a number of conceptual and methodological issues (Wilson and Drury 1984).

The groups of indicators of morbidity listed above are not all of the same nature. Incidence and prevalence rates and answers to health questionnaires give an impression of the presence of morbidity itself, whereas the use of health care facilities, sickness absenteeism and work disability can be considered the consequences of morbidity. With this distinction in mind we shall continue to treat all these categories as indicators of morbidity in the population, although this is not accepted practice for everybody. A brief description of each group is given below.

a) The incidence and prevalence rates for diseases provide more or less "objective" information on morbidity. 
The incidence rate for a disease is the annual number of new cases of that disease per 1,000 (or 100,000 etc.) of population.

The prevalence rate for a disease is the number of cases of that disease present per 1,000 (or 100,000 etc.) of population at a certain moment in time.

One problem about incidence and prevalence is that they are not routinely registered for most of the common diseases. Another problem is that even such relatively straightforward measures as incidence and prevalence depend on the completeness and quality of registration. An extra difficulty with incidence is that the onset of many chronic diseases such as diabetes or arthritis cannot be pinpointed.

In the Netherlands, the nationwide cancer registry has been operational since 1988 only, although part of the country has a much longer tradition in this field (Muir et al 1987).

A number of communicable diseases have to be reported to regional and national health authorities, but there is much underreporting.

An impression of the incidence and prevalence of the various manifestations of atherosclerotic disease has to be obtained in an indirect way, from hospital admissions and local surveys (Fracheboud 1987).

Incidence data on several diseases can be obtained by extrapolation from sentinel stations of general practitioners. Other data on incidence and prevalence have to be estimated from the records of hospitals and other health care institutions. In the Netherlands, there are national registries for injuries resulting from traffic and domestic accidents and for occupational accidents and disease, there are two regional registries for congenital disease and various other sources of information (van der Maas et al 1989).

$\mathrm{b}$ and $\mathrm{c}$ )

The prevalence of chronic non-fatal disease, impairments, disabilities and handicaps can only be estimated by using various sources of information: national and local surveys, epidemiological research, data from general practitioners and hospitals, work disability figures, etc.

There are two national surveys in the Netherlands that can be used for this purpose, the Quality of Life Survey (every 3 years since 1974 and continu- 
ously since 1989) and the Health Interview Survey (continuously since 1981), both conducted by the Netherlands Central Bureau of Statistics. Theoretically it is possible to study trends in self-rated health status and medical consumption with the help of these surveys. In practice, however, the comparability of the answers to questions in both surveys is limited because of changing formulation of questions, changing survey techniques and possibly also changing views on health and illness.

d) Much is known about the use of health care facilities by the Dutch population, although in many cases only for a comparatively short period of time. The CBS and the Dutch Centre for Health Care Information (SIG) regularly publish overviews of the number of consultations with general practitioners and other health workers, the use of beds in hospitals and other health care institutions and the use of pharmaceuticals (CBS 1980; CBS 1986; CBS 1989; van der Maas et al 1989). Some trends are described in chapter 5.

Information on consultations with medical specialists on an out-patient basis is at present less detailed than the other data mentioned here.

The limitation of using health care consumption by the population as an indicator of morbidity is that not all morbidity leads to consumption and not all consumption is justified by morbidity. Moreover, health care use is influenced by many factors other than the presence of morbidity.

e) Sickness absenteeism and work disability will be discussed in $\S 2.7$.

f) The presence of one or more known determinants of disease in a person does not in itself constitute ill-health. Often this presence remains unknown unless revealed by screening programmes or until the disease becomes manifest. This is of course not the case for evident life-style factors such as smoking. We know that the prevalence of these determinants is associated with the incidence of certain diseases, and in this indirect way the prevalence of determinants of disease can be considered part of the health profile of a population. Although determinants of health, risk factors and risk indicators do not have precisely the same meaning, in this report they will be used interchangeably.

Trends in smoking prevalence in the Netherlands are shown in figure 2.5. 
Figure 2.5 Smoking prevalence (in $\chi$ ) in the Netherlands, 1958-1989, among males and females 15 years of age and older.

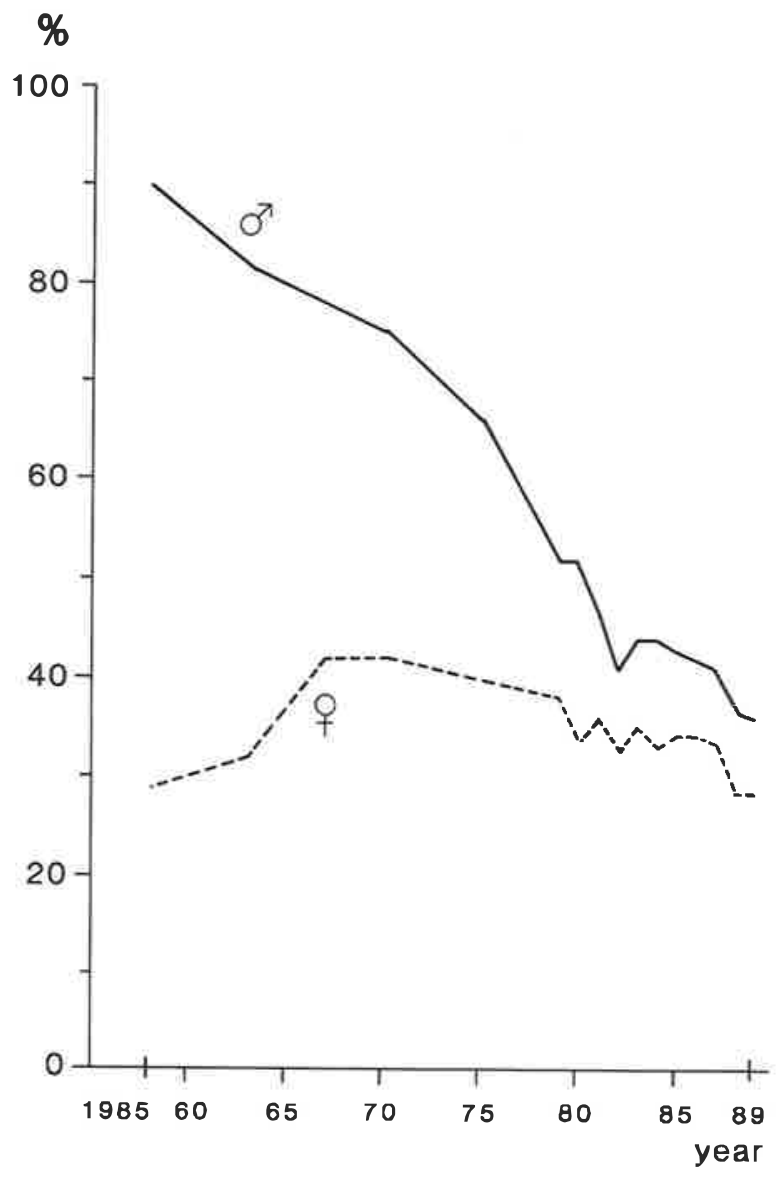

Source: Annual Report 1989, Dutch Foundation on Smoking and Health

In this report, we shall not go into the subject of positive health indicators such as the famous two glasses of wine a day, immunization uptake, seatbelt use or physical activity (Catford 1983; Shephard 1985; Abelin 1986; Ferrence et al 1986; Shaper et al 1987; Ekelund et al 1988; Owens et al 1990). Nor will we touch upon obvious risk indicators that we can do nothing about - unless life style factors are involved, - such as being male (shorter life expectancy) or being elderly (higher incidence of cancer and cardiovascular disease). 
Tables and graphs on morbidity could fill a report by themselves. For these data, the reader is referred to the regular publications of the Netherlands Central Bureau of Statistics (CBS 1980; CBS 1986; CBS 1989) and the Dutch Centre for Health Care Information.

A few key figures on morbidity in the Netherlands are presented in table 2.6. This does not even begin to resemble a full health profile, but it does give a quick impression.

Rank orders for various health problems, according to the morbidity indicator used, are presented in table 2.7. Incidence and prevalence rates are rough estimates: the choice of which type and degree of infection or nervousness should be included is arbitrary, for example. There are minor and major complaints, and they last from a few hours to life-long. The reason why somebody consults a general practitioner is influenced by many factors and the diagnosis is not always clear-cut. Nursing home and especially hospital statistics are more reliable in this respect. The purpose of table 2.7 is to convey the message that rank orders vary enormously, depending on the morbidity indicator used.

\subsection{Disability-free life expectancy}

Disability-free life expectancy is an indicator of health that provides condensed information on mortality on the one hand and morbidity and/or disability on the other. This indicator has also been named active life expectancy or health expectancy in the international literature. Although the three terms do not have precisely the same meaning for everybody, they will be used as equivalents in this report. The results of NIPG-TNO/CBS research on this subject have been described elsewhere (van Ginneken et al 1989); here only a summary will be given.

Simply put, health expectancy is life expectancy minus the years spent in less than good health; in other words, the number of years a person can expect to live in good health, without disease, disability and limitations. 
Table 2.6 Some key figures on morbidity in the Netherlends

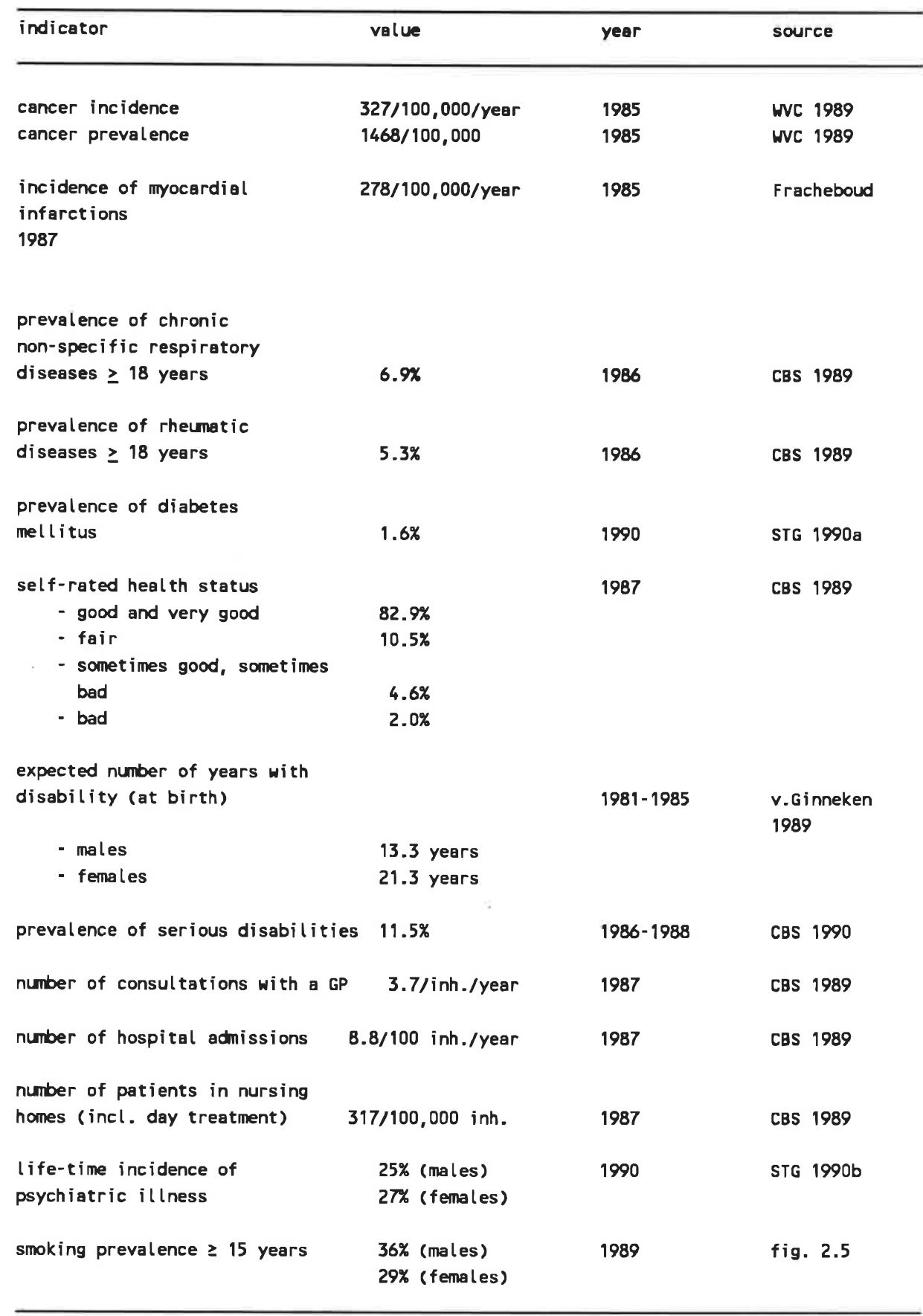


Table 2.7 Rank order (1-5) of health problems in the Netherlands according to morbidity indicator used

\begin{tabular}{|c|c|c|c|c|c|}
\hline & & & RANK ORDER & & \\
\hline & $\begin{array}{l}\text { incidence } \\
\text { rate } \\
\text { (estimate) }\end{array}$ & $\begin{array}{l}\text { prevalence } \\
\text { rate (v.d. } \\
\text { Berg 1989; } \\
\text { STG 1990b) }\end{array}$ & $\begin{array}{l}\text { consultation } \\
\text { with GP } \\
\text { (v.d.Velden } \\
\text { et ol 1990) }\end{array}$ & $\begin{array}{l}\text { hospital } \\
\text { admissions } \\
\text { (CBS 1989) }\end{array}$ & $\begin{array}{l}\text { patients in } \\
\text { nursing homes } \\
\text { (main diag- } \\
\text { noses) } \\
\text { (CBS 1989) }\end{array}$ \\
\hline Infectious diseases & 1 & & 2 & & \\
\hline Neoplasms & & & & 4 & \\
\hline Mental disorders & 4 & 1 & 5 & & 1 \\
\hline \multicolumn{6}{|c|}{ Diseases of the nervous } \\
\hline \multicolumn{6}{|l|}{ Diseases of the circu- } \\
\hline $\begin{array}{l}\text { Diseases of the respi } \\
\text { ratory system }\end{array}$ & & 5 & & & \\
\hline \multicolumn{6}{|l|}{ Diseases of the diges- } \\
\hline $\begin{array}{l}\text { Diseases of the genit } \\
\text { urinary system }\end{array}$ & & & 4 & & \\
\hline \multicolumn{6}{|c|}{ Complications of pregnancy, } \\
\hline Diseases of the skin & 5 & & & & \\
\hline $\begin{array}{l}\text { Diseases of the muscu } \\
\text { skeletal system }\end{array}$ & lo- & 2 & 3 & 2 & 4 \\
\hline Injuries and poisonin & 3 & & & & 5 \\
\hline
\end{tabular}


Details of the procedures for calculation of health expectancy in other countries can be found elsewhere (Sullivan 1971a; Sullivan 1971b; Colvez and Blanchet 1983; Wilkins and Adams 1983; Katz et al 1983; Robine 1989). For the Netherlands, van Ginneken et al have used two different methods.

For the first method, years in less than good health were determined for a prolonged stay in institutions, long-term disability in the non-institutionalized population and short-term limitation of activity in the non-institutionalized population. Institutions were psychiatric hospitals, nursing homes, homes for the mentally deficient and - to some extent - homes for the aged. Information about the non-institutionalized population was based on answers to a large number of questions in the Dutch Health Interview Survey. These questions were based in particular on the so-called OECD-indicator; the disability rates found with this indicator needed adjustment.

For the second method, the prevalence of a prolonged stay in an institution was determined in the same manner as for method one. Information about the noninstitutionalized population was obtained from a single question in the Health Interview Survey: "How do you judge your general state of health?" Those who replied that their health situation was "fair", "sometimes good and sometimes bad", or "bad" were considered to be in less than good health.

The results of the calculation of the degree of disability per age group are presented in table 2.8 (method 1 ) and table 2.9 (method 2). Long-term disability outside institutions is by far the most important form of disability, and females generally fare worse than males.

Life expectancy at various ages with and without disability is presented in table 2.10 (method 1$)$ and table 2.11 (method 2). At older ages, more years are spent with disability than without.

Table 2.12 shows the active life expectancy calculated for five countries. The differences between countries are probably to a large extent attributable to methodological differences rather than real differences in the prevalence of morbidity. It is therefore desirable that definitions of concepts, measurement instruments and calculation procedures be standardized in the near future (Robine and Blanchet 1990). This is also important because an increase in health 
expectancy has been chosen implicitly as the fourth European health objective (see Appendix).

Table 2.8 Percentage of Dutch population with types of disability listed according to age and sex, 1981-1985 (Method 1)

\begin{tabular}{|c|c|c|c|c|c|c|c|c|}
\hline \multirow[t]{2}{*}{ AGE } & \multirow[b]{2}{*}{$\begin{array}{l}\text { In } \\
\text { insti- } \\
\text { tutions }\end{array}$} & \multirow[b]{2}{*}{$\begin{array}{l}\text { Outside } \\
\text { Long- } \\
\text { term } \\
\text { disabi- } \\
\text { lity }\end{array}$} & \multicolumn{2}{|l|}{ MEN } & \multirow[b]{2}{*}{$\begin{array}{l}\text { In } \\
\text { inst i - } \\
\text { tutions }\end{array}$} & \multirow[b]{2}{*}{$\begin{array}{l}\text { Outside } \\
\text { Long- } \\
\text { term } \\
\text { disabi- } \\
\text { lity }\end{array}$} & \multicolumn{2}{|l|}{ WOMEN } \\
\hline & & & $\begin{array}{l}\text { instit. } \\
\text { Short- } \\
\text { term } \\
\text { disabi- } \\
\text { lity }\end{array}$ & Total & & & $\begin{array}{l}\text { instit. } \\
\text { Short- } \\
\text { term } \\
\text { disabi- } \\
\text { lity }\end{array}$ & Total \\
\hline $0-4$ & 0.0 & 3.0 & 3.2 & 6.2 & 0.0 & 2.0 & 3.4 & 5.4 \\
\hline $5-9$ & 0.1 & 3.0 & 3.0 & 6.1 & 0.1 & 2.5 & 3.1 & 5.7 \\
\hline $10-14$ & 0.3 & 3.0 & 2.0 & 5.3 & 0.2 & 3.0 & 2.6 & 5.8 \\
\hline $15-19$ & 0.4 & 2.8 & 2.7 & 5.9 & 0.3 & 6.2 & 5.1 & 11.6 \\
\hline $20-24$ & 0.5 & 3.8 & 4.5 & 8.8 & 0.3 & 7.5 & 5.8 & 13.6 \\
\hline $25-29$ & 0.5 & 3.8 & 5.3 & 9.6 & 0.4 & 7.9 & 6.8 & 15.1 \\
\hline $30-34$ & 0.5 & 3.7 & 5.8 & 10.0 & 0.4 & 8.5 & 7.7 & 16.6 \\
\hline $35-39$ & 0.3 & 6.7 & 6.2 & 13.2 & 0.3 & 9.3 & 5.8 & 15.4 \\
\hline $40-44$ & 0.4 & 8.0 & 7.1 & 15.5 & 0.4 & 13.3 & 6.2 & 19.9 \\
\hline 45-49 & 0.5 & 13.9 & 7.1 & 21.5 & 0.5 & 18.7 & 6.3 & 25.5 \\
\hline $50-54$ & 0.5 & 18.2 & 6.9 & 25.6 & 0.5 & 20.6 & 5.6 & 26.7 \\
\hline 55-59 & 0.5 & 19.0 & 5.7 & 25.2 & 0.5 & 28.9 & 5.3 & 34.7 \\
\hline $60-64$ & 0.6 & 25.9 & 5.9 & 32.4 & 0.6 & 30.2 & 4.4 & 35.2 \\
\hline $65-69$ & 1.1 & 25.0 & 4.4 & 30.5 & 1.6 & 42.0 & 4.3 & 47.9 \\
\hline $70-74$ & 2.5 & 29.5 & 3.4 & 35.4 & 4.0 & 45.5 & 3.8 & 53.3 \\
\hline $75+$ & 13.9 & 43.0 & 2.4 & 59.3 & 22.3 & 49.4 & 2.3 & 74.0 \\
\hline \multicolumn{9}{|l|}{ Total } \\
\hline $\begin{array}{l}\text { (not stand.) } \\
\text { Total }\end{array}$ & 1.0 & 9.9 & 4.7 & 15.6 & 1.9 & 15.9 & 5.0 & 22.8 \\
\hline (stand.) & 1.2 & 10.6 & 4.7 & 16.5 & 1.6 & 15.0 & 5.1 & 21.6 \\
\hline
\end{tabular}

Notes: 1) Average of male and female Dutch population at the end of 1983 was used as standard for standardization procedure

2) Total population is defined as male or female population in institutions and outside institutions

Based on: van Ginneken et al 1989 
Iable 2.9 Percentage of Dutch population in institutions ond outside institutions in less than good health according to age and sex, 1981-1985 (Method 2)

\begin{tabular}{|c|c|c|c|c|c|c|}
\hline \multirow[t]{2}{*}{ AGE } & \multicolumn{3}{|c|}{ MEN } & \multicolumn{3}{|c|}{ HOMEN } \\
\hline & $\begin{array}{l}\text { In } \\
\text { insti- } \\
\text { tutions }\end{array}$ & $\begin{array}{l}\text { Outside } \\
\text { insti- } \\
\text { tutions }\end{array}$ & Total & $\begin{array}{l}\text { In } \\
\text { insti- } \\
\text { tutions }\end{array}$ & $\begin{array}{l}\text { Outside } \\
\text { insti- } \\
\text { tutions }\end{array}$ & Total \\
\hline $0-4$ & 0.0 & 10.1 & 10.4 & 0.0 & 6.2 & 6.2 \\
\hline 5-9 & 0.1 & 8.6 & B.7 & 0.1 & 8.0 & 8.1 \\
\hline $10-14$ & 0.3 & 5.0 & 5.3 & 0.2 & 5.6 & 5.8 \\
\hline $15-19$ & 0.4 & 4.8 & 5.2 & 0.3 & 9.2 & 9.5 \\
\hline $20-24$ & 0.5 & 5.3 & 5.8 & 0.3 & 8.9 & 9.2 \\
\hline $25-29$ & 0.5 & 7.4 & 7.9 & 0.4 & 10.1 & 10.5 \\
\hline $30-34$ & 0.5 & 10.3 & 10.8 & 0.4 & 12.5 & 12.9 \\
\hline $35-39$ & 0.3 & 12.7 & 13.0 & 0.3 & 15.3 & 15.6 \\
\hline $40-44$ & 0.4 & 13.8 & 14.2 & 0.4 & 21.3 & 21.5 \\
\hline $45-49$ & 0.5 & 21.6 & 22.1 & 0.5 & 24.0 & 24.5 \\
\hline $50-54$ & 0.5 & 30.3 & 30.8 & 0.5 & 30.0 & 30.5 \\
\hline $55-59$ & 0.5 & 33.9 & 34.4 & 0.5 & 33.5 & 34.0 \\
\hline $60-64$ & 0.6 & 34.5 & 35.1 & 0.6 & 35.4 & 36.0 \\
\hline $65-69$ & 1.1 & 35.3 & 36.4 & 1.6 & 37.9 & 39.5 \\
\hline $70-74$ & 2.5 & 38.3 & 40.8 & 4.0 & 37.4 & 41.4 \\
\hline 75+ & 13.9 & 35.6 & 49.5 & 22.3 & 34.8 & 57.1 \\
\hline \multicolumn{7}{|l|}{ Total } \\
\hline $\begin{array}{l}\text { (not stand.) } \\
\text { Total }\end{array}$ & 1.0 & 15.3 & 16.2 & 1.9 & 18.3 & 20.2 \\
\hline (stand.) & 1.2 & 15.9 & 17.1 & 1.6 & 17.7 & 19.3 \\
\hline
\end{tabular}

Notes: 1) See notes for table 2.8

2) The data on less than good health outside institutions refer to the period 1983-1987.

Based on: van Ginneken et al 1989 
Table 2.10 Life expectancy in the Netherlands with and without disability (in years) according to age and sex calculated from data on long-term and short-term Iimitation of activity (Method 1), 1981-1985

\begin{tabular}{|c|c|c|c|c|c|c|c|}
\hline $\begin{array}{l}\text { Age } \\
\text { and } \\
\text { sex }\end{array}$ & $\begin{array}{l}\text { Total } \\
\text { Life } \\
\text { expec- } \\
\text { tancy }\end{array}$ & $\begin{array}{l}\text { In } \\
\text { insti- } \\
\text { tutions }\end{array}$ & $\begin{array}{l}\text { Outside } \\
\text { Long- } \\
\text { term } \\
\text { dis- } \\
\text { ability }\end{array}$ & $\begin{array}{l}\text { instit. } \\
\text { Short- } \\
\text { term } \\
\text { dis- } \\
\text { ability }\end{array}$ & $\begin{array}{l}\text { Total } \\
\text { with } \\
\text { dis- } \\
\text { ability }\end{array}$ & $\begin{array}{l}\text { Total } \\
\text { without } \\
\text { dis- } \\
\text { ability }\end{array}$ & $\begin{array}{l}\text { Cumulative } \\
\text { \% with } \\
\text { dis- } \\
\text { ability }\end{array}$ \\
\hline
\end{tabular}

MEN

\begin{tabular}{|c|c|c|c|c|c|c|c|}
\hline 0 & 72.8 & 1.0 & 8.9 & 3.5 & 13.3 & 59.5 & 18.3 \\
\hline 15 & 58.8 & 1.0 & 8.5 & 3.1 & 12.6 & 46.2 & 21.4 \\
\hline 30 & 44.4 & 0.9 & 8.1 & 2.5 & 11.5 & 32.9 & 26.0 \\
\hline 45 & 30.2 & 0.9 & 7.4 & 1.6 & 9.8 & 20.3 & 32.6 \\
\hline 60 & 17.5 & 0.9 & 5.5 & 0.7 & 7.1 & 10.5 & 40.4 \\
\hline 75 & 8.5 & 1.2 & 3.6 & 0.2 & 5.0 & 3.4 & 59.6 \\
\hline \multicolumn{8}{|c|}{ WOMEN } \\
\hline 0 & 79.5 & 2.5 & 15.0 & 3.8 & 21.3 & 58.2 & 26.8 \\
\hline 15 & 65.3 & 2.5 & 14.8 & 3.4 & 20.7 & 44.6 & 31.7 \\
\hline 30 & 50.6 & 2.4 & 13.8 & 2.5 & 18.8 & 31.8 & 37.1 \\
\hline 45 & 36.2 & 2.4 & 12.5 & 1.6 & 16.4 & 19.8 & 45.4 \\
\hline 60 & 22.7 & 2.5 & 9.6 & 0.8 & 12.9 & 9.8 & 56.8 \\
\hline 75 & 11.1 & 2.8 & 5.3 & 0.2 & 8.3 & 2.8 & 74.8 \\
\hline
\end{tabular}

Source: van Ginneken et al 1989 
Table 2.11 Life expectancy in the Metherlands in less than good and in good health (in years) according to age and sex based on perceived health status (Method 2), $1981-1985$

\begin{tabular}{|c|c|c|c|c|c|c|}
\hline $\begin{array}{l}\text { Age } \\
\text { and } \\
\text { sex }\end{array}$ & $\begin{array}{l}\text { Total } \\
\text { life } \\
\text { expec- } \\
\text { tancy }\end{array}$ & $\begin{array}{l}\text { In } \\
\text { insti - } \\
\text { tutions }\end{array}$ & $\begin{array}{l}\text { Out- } \\
\text { side } \\
\text { insti- } \\
\text { tutions }\end{array}$ & $\begin{array}{l}\text { Total } \\
\text { in less } \\
\text { than good } \\
\text { health }\end{array}$ & $\begin{array}{l}\text { Total } \\
\text { in good } \\
\text { health }\end{array}$ & $\begin{array}{l}\text { Cumulative } \\
\text { \% with less } \\
\text { than good } \\
\text { health }\end{array}$ \\
\hline \multicolumn{7}{|l|}{ MEN } \\
\hline 0 & 72.8 & 1.0 & 13.0 & 14.0 & 58.9 & 19.2 \\
\hline 15 & 58.8 & 1.0 & 12.0 & 12.9 & 45.9 & 22.0 \\
\hline 30 & 44.4 & 0.9 & 11.2 & 12.2 & 32.3 & 27.4 \\
\hline 45 & 30.2 & 0.9 & 9.6 & 10.5 & 19.7 & 34.7 \\
\hline 60 & 17.5 & 0.9 & 6.1 & 7.0 & 10.5 & 39.9 \\
\hline 75 & 8.5 & 1.2 & 3.0 & 4.2 & 4.2 & 49.9 \\
\hline \multicolumn{7}{|c|}{ WOMEN } \\
\hline 0 & 79.5 & 2.5 & 16.3 & 18.8 & 60.7 & 23.6 \\
\hline 15 & 65.3 & 2.5 & 15.5 & 18.0 & 47.3 & 27.5 \\
\hline 30 & 50.6 & 2.4 & 14.2 & 16.6 & 34.0 & 32.8 \\
\hline 45 & 36.2 & 2.4 & 11.9 & 14.3 & 21.9 & 39.5 \\
\hline 60 & 22.7 & 2.5 & 8.1 & 10.5 & 12.2 & 46.3 \\
\hline 75 & 11.1 & 2.8 & 3.7 & 6.5 & 4.7 & 58.0 \\
\hline
\end{tabular}

Source: van Ginneken et al 1989 
Table 2.12 Heal th expectancy (in years) at birth in 5 countries

\begin{tabular}{|c|c|c|c|c|c|c|}
\hline $\begin{array}{l}\text { Country } \\
\text { and } \\
\text { sex }\end{array}$ & $\begin{array}{l}\text { Total } \\
\text { life } \\
\text { expec- } \\
\text { tancy }\end{array}$ & $\begin{array}{l}\text { In } \\
\text { inst } i- \\
\text { tutions }\end{array}$ & $\begin{array}{l}\text { Outside } \\
\text { Long- } \\
\text { term } \\
\text { dis- } \\
\text { ability }\end{array}$ & $\begin{array}{l}\text { instit. } \\
\text { Short- } \\
\text { term } \\
\text { limi- } \\
\text { tations }\end{array}$ & $\begin{array}{l}\text { Total } \\
\text { with } \\
\text { dis- } \\
\text { ability }\end{array}$ & $\begin{array}{l}\text { Total } \\
\text { without } \\
\text { dis- } \\
\text { ability }\end{array}$ \\
\hline
\end{tabular}

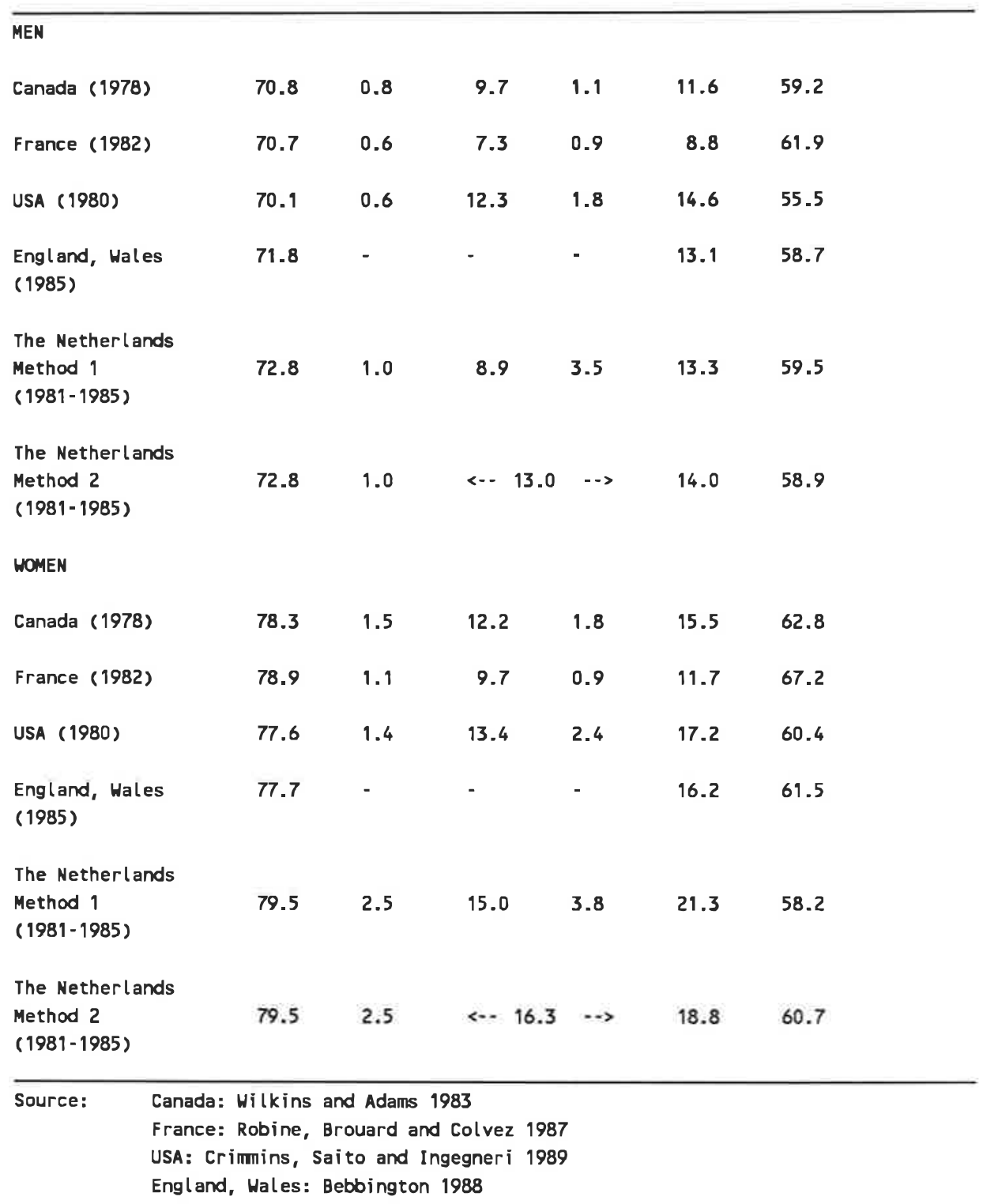


As will be explained in chapter 3, an increase in health expectancy cannot be used as an indicator of the health benefit achieved with specific preventive measures. However, as a comprehensive indicator of the health status of a population, health expectancy is probably unsurpassed. Monitoring health expectancy is therefore highly desirable. Trends in health expectancy in some other countries will be described in chapter 5; for the Netherlands this was not possible because some data are not available.

\subsection{Economic costs of morbidity and mortality}

We shall now look at a different aspect of morbidity and mortality in the population, namely the economic burden caused by illness and premature death. Both illness and premature death represent costs to society. Economists make a distinction between the direct and indirect costs of illness. Direct costs are the costs of foregone alternatives: if there were no illness, then the money spent on diagnosing, treating and caring for the sick and the money spent on prevention could be put to other uses. Indirect costs are the value of the output that is lost because people are too ill to work or have died prematurely. Economic costs are useful indicators of the economic burden which individual diseases place on a society.

The costs of morbidity can be broadly defined as the expenditure on health care in an economy, the loss of output due to sickness absenteeism and work disability and the personal costs of pain and anguish associated with illness. The costs of premature death, apart from the loss and grief to family and friends, are the costs of the loss of potential productive output in the economy.

\subsubsection{Direct and indirect costs of illness}

The direct costs of illness are the costs of health care services for diagnosing and treating illness as well as those of prevention programmes (vaccination, screening, etc.), rehabilitation, research, training and capital investment in medical facilities. These expenditures are taken up in the economy's national accounts. The share of health expenditure in national expenditure has more than 
doubled between 1960 and the 1980's in most industrialized countries: in the United States it rose from 5.3\% of G.D.P.* in 1960 to $9.2 \%$ in 1980 and $11.2 \%$ in 1987; in the United Kingdom from $3.9 \%$ in 1960 to $5.8 \%$ in 1980 and $6.1 \%$ in 1987; in the Netherlands from $3.9 \%$ in 1960 to $8.2 \%$ in 1980 and $8.5 \%$ in 1987 (OECD 1985; U.S. Dept of Health and Human Services 1989). In the 1980's the share of health expenditure has remained more or less stable in the Netherlands as a result of government policy to curb this rising trend, mainly by budgeting hospital expenditure.

The indirect costs of illness, which are the value of lost output incurred through illness, represent losses to the total output of an economy. Income lost due to sickness absenteeism and work disability is used to measure this lost output. Losses due to the illness of housewives or the unemployed who cannot perform their daily tasks are not measured as a rule because the (unpaid) output of nonmarket labour is not considered a part of the national product in national accounting.

The indirect costs of premature death are also losses to the national product, since death means a loss in potential earnings until retirement age. These costs are measured by discounting the stream of potential lifetime earnings. As for the personal pain and anguish due to illness and death, these again are not con-sidered a part of the national product. These costs are known as "intangibles", i.e. costs which cannot be expressed in money terms but which must be taken into account when discussing the impact of illness or death.

\subsubsection{Disease costing}

"Disease costing" is the estimation of the costs of illness, direct and indirect, per diagnostic group, e.g. the costs of cancer or heart disease, or for a single disease, e.g. the costs of diabetes or AIDS. These estimates are used by health planners for a variety of purposes. In the case of a specific disease or diagnostic group,

*G.N.P. (Gross national product) = G.D.P. (Gross domestic product) + net income from abroad 
they may wish, for example, to know the relationship between the direct and indirect costs in order to identify where cost savings might be achieved by means of prevention activities. Disease costing may also be used by planners for comparisons between the relative economic burden of diseases or diagnostic groups and these comparisons may be used for setting priorities in prevention.

Cost of illness studies are useful for identifying how resources are allocated between different types of costs and between different diseases. They cannot, however, tell us whether the resource allocation is efficient. This can only be done through the evaluation of individual programmes (e.g. vaccination or screening) using cost benefit or cost effectiveness techniques (see also $§ 3.6$ ).

When comparisons between diseases are made, it is important that the same methodology be used for all estimates. Rice set out in great detail the methodology for estimating the costs of major diagnostic categories (Rice 1966; Cooper and Rice 1976; Rice et al 1985). Many disease costing studies have been carried out in the United States to assist regional and national planners. U.S. National Health Statistics are now collected in such a way as to facilitate the estimation of costs (see also Hodgson and Meiners 1982; Hodgson 1983). In Europe relatively few disease costing studies have been carried out which cover both direct and indirect costs: the study of Henke and Behrens (1986) for West Germany is the most extensive, since it covers all diagnostic groups.

As an example of what is meant by disease costing in practice, we shall discuss the latest study of Rice $e$ al which is the most comprehensive of all such studies for the U.S. (Rice et al 1985). Their main results are shown in table 2.13.

The direct costs covered hospital and nursing home care, physicians' services, dentists and other professional services, drugs and appliances. They totalled

$\$ 211$ billion in 1980, with diseases of the circulatory system and diseases of the digestive system each accounting for nearly $15 \%$ of the total costs.

The indirect costs of morbidity were calculated for the currently employed, for those keeping house and for those unable to work or in institutions. The estimates for the currently employed were based on foregone earnings. The evaluation for people keeping house (housewives) was based on the market-cost approach, i.e. the cost of replacing housewives' tasks with paid labour to carry out the same work. 

1980 (U.S.A.)

\begin{tabular}{|c|c|c|c|c|c|c|c|c|}
\hline Diagnosis & total & $\begin{array}{l}\text { direct } \\
\text { costs }\end{array}$ & $\begin{array}{l}\text { indirect } \\
\text { morbidity }\end{array}$ & $\begin{array}{l}\text { costs } \\
\text { mortality }\end{array}$ & total & $\begin{array}{l}\text { direct } \\
\text { costs }\end{array}$ & $\begin{array}{l}\text { indirect } \\
\text { morbidity }\end{array}$ & $\begin{array}{l}\text { costs } \\
\text { mortality }\end{array}$ \\
\hline & & \multicolumn{2}{|c|}{ amount in millions (\$) } & \multicolumn{5}{|c|}{ percentage distribution } \\
\hline 1. Infectious and parasitic diseases & 10,266 & 4,300 & 4,107 & 1,859 & 2.3 & 2.0 & 6.1 & 1.1 \\
\hline $\begin{array}{l}\text { 2. Neopl asms } \\
\text { 3. Endocrine, nutritional, metabol ic }\end{array}$ & 50,538 & 13,049 & 5,778 & 31,711 & 11.1 & 6.2 & 8.5 & 18.0 \\
\hline $\begin{array}{l}\text { diseases and immunity disorders } \\
\text { 4. Diseases of blood and blood-forming }\end{array}$ & 12,840 & 7,329 & 2,237 & 3,274 & 2.8 & 3.5 & 3.3 & 1.9 \\
\hline organs & 2,050 & 1,155 & 281 & 614 & 0.5 & 0.5 & 0.4 & 0.3 \\
\hline $\begin{array}{l}\text { 5. Mental disorders } \\
\text { 6. Diseases of the nervous system }\end{array}$ & 30,685 & 19,824 & 8,917 & 1,944 & 6.7 & 9.4 & 13.1 & 1.1 \\
\hline and sense organs & 22,991 & 17,132 & 2,616 & 3,243 & 5.1 & B.1 & 3.9 & 1.8 \\
\hline 7. Diseases of the circulatory system & 85,008 & 32,488 & 11,448 & 41,072 & 18.7 & 15.4 & 16.9 & 23.3 \\
\hline 8. Diseases of the respiratory system & 33,120 & 16,661 & 10,146 & 6,313 & 7.3 & 7.9 & 15.0 & 3.6 \\
\hline 9. Diseases of the digestive system & 42,437 & 30,974 & 3,441 & 8,022 & 9.3 & 14.7 & 5.1 & 4.6 \\
\hline $\begin{array}{l}\text { 10. Diseases of the genitourinary system } \\
\text { 12. Diseases of the skin and }\end{array}$ & 15,414 & 12,313 & 1,762 & 1,339 & 3.4 & 5.8 & 2.6 & 0.8 \\
\hline $\begin{array}{l}\text { subcutaneous } t \text { issue } \\
\text { 13. Diseases of the musculoskeletal }\end{array}$ & 6,600 & 5,940 & 539 & 121 & 1.5 & 2.8 & 0.8 & 0.0 \\
\hline system and connective tissue & 20,588 & 13,124 & 6,938 & 526 & 4.5 & 6.2 & 10.2 & 0.3 \\
\hline $\begin{array}{l}\text { 14. Congenital anomalies } \\
\text { 16. Symptoms, signs and ill-defined }\end{array}$ & 6,319 & 1,345 & $\cdots$ & 4,974 & 1.4 & 0.6 & $*$ & 2.8 \\
\hline conditions & 10,710 & 3,815 & 1,847 & 5,048 & 4.3 & 1.8 & 2.7 & 2.9 \\
\hline 17. Injuries and poisoning & 82,959 & 18,684 & 7,234 & 57,041 & 18.2 & 8.8 & 10.7 & 32.4 \\
\hline other conditions" & 18,093 & 8,746 & 536 & 8,811 & 2.0 & 4.1 & 0.8 & 5.0 \\
\hline 0. Unal located expendi tures & 4,265 & 4,265 & $\cdots$ & $\cdots$ & 0.9 & 2.0 & -. & -. \\
\hline Total & 454,882 & 211,143 & 67,827 & 175,912 & 100.0 & 100.0 & 100.0 & 100.0 \\
\hline
\end{tabular}

Includes complications of pregnancy, childbirth and puerperium and certain conditions originating during the perinatal period (groups 11 and ** 15)

Present value of lifetime earnings discounted at 4 percent

NOTE: numbers and percents may not add due to rounding

(Source: Rice, Hodgson \& Kopstein, 1985) 
The estimates for people generally too ill to be employed or in institutions were based on the assumption that these people would have worked had they not been ill. The estimates were adjusted for current work participation and unemployment rates. The indirect costs of morbidity totalled $\$ 68$ billion. The highest costs were due to diseases of the circulatory system (17\%), followed by diseases of the respiratory system (15\%) and mental disorders (13\%).

The measurement of the costs of mortality is an emotional issue, which is still a source of controversy among economists. The traditional method used is the human capital approach which evaluates premature death in terms of the expected lifetime earnings foregone. This approach gives greater weight to working men than to housewives or the elderly. Yet, as Hodgson and Meiners (1982) point out, this approach does not measure the "value of life" but a certain component of the cost of a disease, namely the economic burden that premature death places on the potential output of an economy. This method, however, assumes a situation of full employment. The premature death of one person may mean the employment of an unemployed person in times of unemployment. So far no real solution has been found to overcome the consequences of this assumption in the human capital approach.

Economists have devised other approaches for estimating the costs of premature mortality. One of them is the "willingness to pay" approach, which measures the value of human life by the amount people are willing to spend to reduce the probability of death (e.g. via insurance payments). The problem with this method is that it is difficult to make a direct link between expenses paid and a reduction in probability of death. In practice few estimates have been based on this method (Hodgson 1983; Hay 1989).

Rice et al use the human capital approach for their estimates of the costs of mortality. The loss of potential earnings due to premature death has been discounted with a discount rate of $4 \%$. The lower the discount rate, the higher the stream of foregone earnings. (Discounting will be explained in chapter 3). The total costs of premature mortality discounted at $4 \%$ are $\$ 176$ billion. Injury and poisoning accounted for the highest percentage of costs (32\%), followed by diseases of the circulatory system (23\%) and neoplasms (18\%). 
When we now look at the column "total" in table 2.13 , we see that the overall rank order places diseases of the circulatory system first, injury and poisoning second and neoplasms third. One of the advantages of disease costing is that it enables one to establish an overall rank order after adding the separate categories of costs, something which cannot be done with the other health measures described in this chapter.

\subsubsection{Disease costing in the Netherlands}

In the Netherlands disease costing studies have only been carried out for a particular disease or diagnostic group, such as diseases of the circulatory system (CBS/TNO 1980; STG 1987; Verkooijen et al 1990), diseases of the respiratory system (Mölken 1989) and AIDS (Wiggers and Bergsma 1990). The main reason for this is that the direct costs of health care are very difficult to estimate per diagnostic category because the accounting procedures of the health care services are not broken down systematically according to diagnostic group. Moreover the indirect costs of morbidity are seldom calculated; when available, they are usually approximations based on actual insurance benefits paid out. In a recent NIPG report (Bergsma and van Ginneken 1990), however, the indirect costs of morbidity in the working population were estimated for all diagnostic groups in the Netherlands in 1985. These figures could be used in conjunction with other health indicators in setting up a national prevention profile.

\section{Data and methods}

In the Netherlands, data on sickness absenteeism are published yearly per main diagnostic group by the Central Bureau of Statistics. The source for the data are the industrial insurance boards who are responsible for the data collection. The size of the working population covered by these statistics is 2.7 million out of a total working population of 5.1 million. Approximately 3.4 million people are covered by the Sickness Benefits Act, i.e. the 2.7 million mentioned above and large firms carrying their own risk. Selfemployed persons do not fall under this Act. Civil servants, the armed forces and people in military service and employees of the national railways have their own separate ruling. No statistics on 
sickness absenteeism are available according to diagnosis for the 2.4 million not included in the population of the Central Bureau of Statistics mentioned above. In the absence of further information the assumption had to be made that their absence rate was the same as that for the first group.

The value of lost production through sickness absenteeism was first calculated for each diagnostic group on the basis of the available data and then a further estimate was made of the costs of the remaining sickness absenteeism which could not be classified into diagnostic groups.

For work disability the available statistics are much more complete and are collected by the Work Disablement Funds. The value of lost production was calculated for each diagnostic group and adjusted with the unemployment rates.

\section{The costs of sickness absenteeism}

Sickness absenteeism in the Netherlands applies to short-term illness, i.e. illness that lasts less than one year. During the period of illness employees are usually paid their full wages with the exception of the first few days which are not always reimbursed, depending on the rules of the industrial insurance boards to which the employer belongs. The implementing body of each industrial insurance board has the responsibility of ensuring that benefits are only paid out to people who are absent due to illness.

The number of days lost through sickness absenteeism and the costs of lost production were first calculated per disease category for the population of 2.7 million for which detailed statistics were available (see table 2.14). For this group the total number of days lost was estimated to be 75 million; lost production was $f 8.7$ billion or $\$ 3.4$ billion (at a purchasing power parity for G.D.P. of $\$ 1=$ f 2.55, U.S. Dept. of Health and Human Services 1989).

The disease categories producing the highest costs of sickness absenteeism were diseases of the musculoskeletal system and connective tissue (22\% of the total costs), mental disorders (16\%) and external causes of injury and poisoning (6\%). A further $30 \%$ of the costs were due to short term periods of illness of 10 days on average where the employee was not seen by a medical practitioner and for which consequently no diagnosis could be made. 
Table 2.14 Number of days and value of production lost due to sickness absenteeism in 2.7 million of the working population in the Netherlands in 1985, per diagnostic group

\begin{tabular}{|c|c|c|c|c|c|}
\hline \multirow[t]{2}{*}{ Diagnosis } & \multicolumn{3}{|c|}{$\begin{array}{l}\mathrm{nr} \text { of days lost due to } \\
\text { sickness absenteeism } \\
\left(\begin{array}{ll}x \quad 1000\end{array}\right)\end{array}$} & \multirow[t]{2}{*}{$\begin{array}{l}\text { total value of } \\
\text { lost production } \\
(x \neq 1 \text { million)* }\end{array}$} & \multirow[t]{2}{*}{$\begin{array}{l}\text { order of } \\
\text { rank }\end{array}$} \\
\hline & men & women & total & & \\
\hline 1. Infectious and parasitic diseases & 392 & 271 & 663 & 68 & 13 \\
\hline 2. Neopl asms & 482 & 340 & 822 & 107 & 11 \\
\hline 3. Endocrine, nutritional, metabolic diseases & & & & & \\
\hline and immunity disorders & 203 & 148 & 351 & 43 & 14 \\
\hline 4. Diseases of blood and blood-forming organs & 39 & 62 & 100 & 11 & 16 \\
\hline 5. Mental disorders & 6,810 & 4,646 & 11,456 & 1,368 & 2 \\
\hline 6. Diseases of the nervous system and sense organs & 999 & 490 & 1,490 & 181 & 9 \\
\hline 7. Diseases of the circulatory system & 2,296 & 444 & 2,740 & 389 & 4 \\
\hline 8. Diseases of the respiratory system & 2,039 & 1,352 & 3,391 & 381 & 5 \\
\hline 9. Diseases of the digestive system & 1,640 & 704 & 2,344 & 278 & 7 \\
\hline 10. Diseases of the genitourinary system & 390 & 820 & 1,210 & 140 & 10 \\
\hline 11. Complications of pregnancy, childbirth and puerperium & $\cdots$ & 3,677 & 3,677 & 338 & 6 \\
\hline 12. Diseases of the skin and subcutaneous tissue & 431 & 295 & 726 & 77 & 12 \\
\hline 13. Diseases of the musculoskeletal system and connective tissue & 1,209 & 4,238 & 15,447 & 1,912 & 1 \\
\hline $\begin{array}{l}\text { 14. Congenital anomal } i \text { es } \\
\text { 14. }\end{array}$ & 105 & 4,230 & 150 & 16 & 15 \\
\hline 16. Symptoms, signs and ill-defined conditions & 1,738 & 403 & 2,142 & 257 & 8 \\
\hline 17. Injuries and poisoning & 3,905 & 1,121 & 5,027 & 544 & 3 \\
\hline 0 . No medical diagnosis & 14,674 & 8,935 & 23,609 & 2,619 & . \\
\hline Total & 47,352 & 27,991 & 75,342 & 8,726 & - \\
\hline
\end{tabular}

$f 1=\$ 2.55$ at purchasing power parity for G.D.P. (1985)

(Source: Bergsma \& van Ginneken, 1990) 


\begin{tabular}{lrrrr}
\hline Diagnosis & \multicolumn{2}{c}{$\begin{array}{c}\text { nr of days lost due to } \\
\text { work disability } \\
\text { (x 1000) }\end{array}$} & $\begin{array}{c}\text { total value of } \\
\text { lost production* } \\
\text { (x f } \begin{array}{l}\text { order of } \\
\text { million)** }\end{array}\end{array}$ \\
\hline rank
\end{tabular}

* corrected for work participation rates

(Source: Bergsma \& van Ginneken, 1990) 
Table 2.16 Estimates of value of production lost due to sickness absenteeism and work disability in the Netherlands in 1985 , per diagnostic group

\begin{tabular}{|c|c|c|c|c|}
\hline \multirow[t]{2}{*}{ Diagnose } & \multicolumn{2}{|c|}{$\begin{array}{l}\text { value of lost production } \\
\qquad(x \in 1 \mathrm{million})\end{array}$} & \multirow[t]{2}{*}{$\begin{array}{c}\text { total } \\
(x+1 \text { million })\end{array}$} & \multirow[t]{2}{*}{$\begin{array}{l}\text { order of } \\
\text { rank }\end{array}$} \\
\hline & $\begin{array}{l}\text { sickness } \\
\text { absenteeism }\end{array}$ & $\begin{array}{l}\text { work } \\
\text { disability }\end{array}$ & & \\
\hline 1. Infectious and parasitic diseases & 68 & 108 & 176 & 14 \\
\hline 2. Neopl asms & 107 & 302 & 409 & 9 \\
\hline 3. Endocrine, nutritional, metabolic diseases & & & & \\
\hline and immunity disorders & 43 & 157 & 200 & 12 \\
\hline 4. Diseases of blood and blood-forming organs & 11 & 25 & 36 & 16 \\
\hline 5. Mental disorders & 1,368 & 3,868 & 5,236 & 2 \\
\hline 6. Diseases of the nervous system + sense organs & 181 & 813 & 994 & 6 \\
\hline 7. Diseases of the circulatory system & 398 & 2,008 & 2,397 & 3 \\
\hline 8. Diseases of the respiratory system & 381 & 696 & 1,077 & 5 \\
\hline 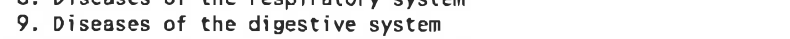 & 278 & 419 & 697 & 7 \\
\hline 10. Diseases of the genitourinary system & 140 & 165 & 305 & 11 \\
\hline 11. Compl ications of pregnancy, childbirth and puerperium & 338 & 11 & 349 & 10 \\
\hline 12. Diseases of the skin and subcutaneous tissue & 77 & 117 & 194 & 13 \\
\hline 13. Diseases of the musculoskeletal system and connective tissue & 1,912 & 4,101 & 6,013 & 1 \\
\hline 14. Congenital anomalies & 16 & 4,101 & 0,07 & 15 \\
\hline 16. Symptoms, signs and ill-defined conditions & 257 & 198 & 455 & $B$ \\
\hline 17. Injuries and poisoning & 544 & 794 & 1,338 & 4 \\
\hline 0 . No medical diagnosis & 2,619 & 2,683 & 5,302 & : \\
\hline $\begin{array}{l}\text { subtotal } \\
\text { unallocated }\end{array}$ & $\begin{array}{l}8,726^{*} \\
4,803^{\text {k* }}\end{array}$ & 16,526 & $\begin{array}{r}25,252 \\
4,803\end{array}$ & \\
\hline Total working population & 13,528 & 16,526 & 30,054 & \\
\hline
\end{tabular}

* costs of sickness absenteeism of 2.7 million working population

t* costs of sickness absenteeism in the remaining working population

(Source: Bergsma \& van Ginneken, 1990 ) 
As for the estimates of sickness absenteeism in the remaining working population, the assumption was made that these rates of absenteeism were similar to those found for the first population. In this way it was estimated that in 1985 127 million full working days were lost due to sickness absenteeism in the total working population of 5.1 million (full-timers and part-timers). The value of lost production was estimated to be $f 13.6$ billion or $\$ 5.3$ billion (see table 2.16 ).

Work disability

Work disability applies to long term illness. If someone who has been absent from work for more than one year has not fully recovered within that year, he is eligible for disablement benefits. Someone is considered disabled when he can no longer satisfactorily perform the last job he had and the amount of benefits paid out is linked to the level of his previous wage, with a fixed ceiling. As a result someone can be considered fully disabled when he can no longer perform his previous job, even though he may be suitable for a totally different occupation. As a rule work disablement benefits are higher than unemployment benefits.

In 1985 it was estimated that 181 million full working days were lost due to work disability (see table 2.15 ). The value of lost production, adjusted for current unemployment rates, was estimated to be $f 16.5$ billion or $\$ 6.5$ billion. The value of lost production was compared with the total disablement benefits paid out: they were almost as high as the value of lost production, confirming the fact that in the Netherlands work disablement benefits ensure that the individuals concerned suffer little financial loss but that the total social burden of such an insurance system is high.

The highest costs for work disability were found for the following disease categories: diseases of the musculoskeletal system and connective tissue (25\%), mental disorders $(23 \%)$ and diseases of the circulatory system (12\%)(see table 2.15$)$.

The total indirect costs of morbidity in the working population

The total indirect costs of morbidity in the working population in 1985 were estimated to be $\int 30.1$ billion or $\$ 11.8$ billion, while the total expenditure on the health care services was $f 34.8$ billion or $\$ 13.6$ billion. When one compares these results with those of the U.S.A. (see table 2.13), there is a great difference be- 
tween the two countries. In the U.S.A. the indirect costs of morbidity are approximately one-third of the total direct costs; in the Netherlands the two are almost the same.

The disease categories responsible for the highest indirect costs of morbidity in the Netherlands were diseases of the musculoskeletal system and connective tissue (mainly back problems), followed by mental disorders (mainly due to adaptation problems and stress at work) and diseases of the circulatory system (see table 2.16). The pattern in the U.S.A. is different: the three most important disease categories are diseases of the circulatory system, diseases of the respiratory system and mental disorders (see table 2.13).

\subsection{Distribution of morbidity and mortality}

Morbidity and mortality are not evenly distributed in and between populations and countries. We have already seen the differences that exist between men and women for a number of indicators. Uneven distribution of health has also been demonstrated for groups of different socio-economic status or living in different geographic areas (Fox 1989).

The first European health target calls for a reduction in existing inequalities of health within and between countries of at least $25 \%$ by the year 2000 , which means that these inequalities must be identified first.

\subsubsection{Geographic variations}

There are many interesting differences in indicators, such as cardiovascular mortality, life expectancy and health care use, between European countries: for example, between Mediterranean countries, central and eastern European countries, Scandinavian countries, etc. This can stimulate research into the causes of these differences with the aim of elucidating various risk factors. In this section we shall only briefly touch upon regional differences in morbidity and mortality that can easily be found even in a small country such as the Netherlands (14.8 $\mathrm{m}$. inhabitants living on $39,600 \mathrm{~km}^{2}$ land in 1988). One can compare the twelve provinces, the 61 health regions or areas with different degrees of urbanization, 
and one will find differences in cancer incidence and mortality (CBS 1980), life expectancy, hospital admission rates and numerous other indicators that can be general or specific for a certain disease. The idea is that if there is an explanation for the differences, prevention might be possible. Unfortunately, the required explanation of ten cannot be found; moreover the differences are not really spectacular (Rosen et al 1985; Wall et al 1985; CBS 1987; Davidse and van de Water 1988; Mackenbach et al 1990).

Since the construction of local and regional health profiles is time-consuming, expensive and complicated, this may not be the most efficient way to stimulate health policy in small countries with a rather homogeneous population. In such countries, national health profiles would suffice. Local or regional implementation of national prevention programmes could then focus on specific components of the programme once it is known that one or two proven risk factors are significantly more prevalent in the municipality or region.

This discussion is still open in the Netherlands. At present, a discussion of local or regional health profiles and prevention programmes was deemed beyond the scope of this report.

\subsubsection{Socio-economic variations}

There are strong and persistent relationships between social class and morbidity and mortality, generally meaning higher values for morbidity and mortality indicators among socially disadvantaged groups (Svensson 1988; Illsley 1988; Marmot 1988; Fox 1990; Kunst et al 1990). This is an important field for research and for politicians. Many explanations have been presented and it is sometimes difficult to separate scientific facts from ideological views. Social class in itself is a rather rough yardstick, being a composite of education, income and occupation; education is generally considered to be the most important element (Winkleby $e t$ al 1990; Doornbos and Kromhout 1990). Although socio-economic-related variations in health are a potentially promising area for prevention programmes, they will not be discussed here because many others have already dealt with this subject. 


\subsection{Discussion}

A number of health indicators can be combined with demographic data to construct a so-called health profile, the first step on the way to a prevention profile, i.e. a coherent prevention policy. The health indicators concern death (e.g. mortality rates, life expectancy and potential years of life lost), disease (e.g. incidence and prevalence rates for various health problems, self-rated health status, use of health care facilities and prevalence of risk indicators), a combination of death and disease (active life expectancy) and socio-economic factors (e.g. sickness absenteeism and work disability).

The demographic data include age distribution, male/female ratio, ethnic background, family structure, social class and place of residence.

The more health indicators and demographic data are used, the more refined the health profile will be, and the more expensive and time-consuming the task will be. We should collect the minimum amount of information that will enable us to carry out the envisioned health policy: "In der Beschränkung zeigt sich erst der Meister" (Goethe 1749-1832). The choice should be such that the health profile will be accepted as a good and efficient picture of the health status of the population by those who have to work with the profile.

One form of refinement is the local or regional health profile for smaller geographic areas. In small countries, such as the Netherlands, the effectiveness and efficiency of the construction and use of regional health profiles and a regional health policy are not yet clear. It may be wiser to develop a national health policy which is then implemented in accordance with regional or local conditions (van de Water 1989). Research is under way in the Netherlands to evaluate the usefulness of regional health profiles.

Each health indicator gives a different impression of the size and seriousness of the various health problems. This is illustrated by the different rank orders given for the health problems listed in tables 2.4 and 2.5 (mortality and potential years of life lost), 2.7 (morbidity) and 2.14-16 (sickness absenteeism, work disability and total indirect economic cost of morbidity). These ordinal positions cannot be added together or otherwise combined to obtain a simple index. Therefore 
everyone has to chose his own rank order for health problems. Obviously, a health economist or a medical insurance company will use a different rank order than a public health official, a politician, a patients' organization or the lay public. However, even without a methodology to weigh and add up the values of the different health indicators for each health problem, it is clear from these tables that, as far as the population is concerned, the following are important health problems that would offer good targets for prevention: cardiovascular disease (mainly coronary atherosclerosis), cancer (especially colorectal, lung and breast cancer), mental and neurological disease (especially psychosocial problems, depression and dementia), musculoskeletal problems (especially (osteo-)arthritis and back pain) and injuries (due to home and leisure accidents rather than traffic or occupational accidents). Cardiovascular disease has high indicators of mortality, morbidity and - to a lesser extent - indirect economic losses; cancer high mortality indicators; mental disease and musculoskeletal problems high morbidity and economic indicators; and injuries high mortality and economic indicators.

Unfortunately, the willingness to prevent major health problems is not always matched by the availability of practical prevention methods. The preventability of health problems and the effectiveness and efficiency of existing prevention methods will be discussed in chapter 3 . 


\section{LITERATURE}

ABELIN T. Positive indicators in health promotion and protection. Wld Hlth Statist Quart $1986 ; 39: 353-64$

BEBBINGTON AC. The expectation of life without disability in England and Wales. Soc Sci Med 1988;27:321-6.

van den BERG $J$, van den BOS GAM. The (measurement of the) prevalence of chronic conditions, 1974-1987 (in Dutch, with summery in English). Maandbericht Gezondheidsstatistiek $1989 ; 8(3): 4-21$.

BERGNER M, ROTHMAN ML. Health status measures: an overview and guide for selection. Ann Rev Public Health 1987;8:191-210.

BERGSMA EW, van GINNEKEN JKS. Een schatting van omvang en kosten van ziekteverzuim en arbeidsongeschiktheid naar diagnose in Nederland (1985) (in Dutch, with summary in English). Leiden (the Netherlands): NIPG-TNO, 1990.

BRESLOW L. Setting objectives for public health. Ann Rev Public Health 1987;8:289-307.

CATFORD JC. Positive health indicators - towards a new information base for health promotion. Community Medicine 1983;5:125-32.

CBS (Netherlands Central Bureau of Statistics) / Ministry of Public Health and Environmental Hygiene. Compendium health statistics of the Netherlands 1979 (bilingual DutchEnglish). The Hague: Staatsuitgeverij, 1980.

CBS. Atlas van de kankersterfte in Nederland 1969-1978 (in Dutch, with summary in English). The Hague: Staatsuitgeverij, 1980.

CBS/TNO. Hart- en vaatziekten: omveng en maatschappelijke betekenis (in Dutch). The Hague: Staatsuitgeverij, 1980.

CBS / Ministry of Welfare, Health and Cultural Affairs. Compendium of health statistics of the Netherlands 1986 (bilingual Dutch-English). The Hague: Staatsuitgeverij, 1986.

CBS. Regional vademecum gezondheidsstatistiek 1985 (in Dutch). The Hague: Staatsuitgeveri $\mathrm{j}, 1987$.

CBS / Ministry of Welfare, Health and Cultural Affairs. Vademecum health statistics of the Netherlands (bilingual Dutch - English). The Hague: SDU-Uitgeverij, 1989.

COLVEZ A, BLANChET M. Potential gains in life expectency free of disability: a tool for health planning. Intern J Epidemiol. 1983;12:224-9.

COOPER BS, RICE DP. The economic cost of illness revisited. Social Security Bulletin $1976 ; 39: 21-35$.

CRIMMINS EM, SAITO $Y$, INGEGNERI D. Changes in life expectancy and disability-free life expectancy in the United States. Pop and Dev Rev 1989;15:235-67.

DAVIDSE W, van de WATER HPA. Regionale gezondheidsverschillen in Zuid-Holland (in Dutch). Leiden (the Netherlands): NIPG-TNO, 1988.

DOORNBOS G, KROMHOUT D. Educational level and mortality in a 32-year follow-up study of 18-year-old men in the Netherlands. Int $J$ Epidemiol

$1990 ; 19: 374-9$

EKELUND LG, HASKELL WL, JOHNSON JL, HHALEY FS, CRIOUI MH, SHEPS DS. Physical fitness as a predictor of cardiovascular mortality in asymptomatic North American men. N Engl J Med 1988; 319: 1379-84 
FERRENCE RG, TRUSCOTT S, WHITEHEAD PC. Drinking and the prevention of coronary heart disease: findings, issues and public health policy. J of studies on Alcohol 1986;47:394-408.

FOX AJ (ed). Health inequalities in European countries. Aldershot (United Kingdom): Gower, 1989.

FOX AJ. Socio-economic differences in mortality and morbidity. Scand J Soc Med 1990; 18:18 .

FRACHEBOUD J. Hartinfarct; hartbewaking of thuisblijven (in Dutch). Utrecht (the Nether(ands): NIVEL, 1987.

VAN GINNEKEN JKS, BANNENBERG AFI, DISSEVELT AG. Gezondheidsverlies ten gevolge van een aantal belangrijke ziektecategorieën in 1981-1985 (in Dutch). Leiden (the Netherlands): NIPG-TNO/CBS, 1989.

HANSLUWKA HE. Measuring the health of populations, indicators and interpretations. Soc Sci Med 1985;20:1207-24.

HAY JW. Econometric issues in modeling the costs of AIDS. Health Policy $1989 ; 11: 125-45$.

HENKE KD, BEHRENS CS. The economic cost of illness in the Federal Republic of Germany in the year 1980. Health Policy 1986;6:119-43.

HOOGSON TA, MEINERS MR. Cost of illness methodology: a guide to current practices and procedures. Milbank Menorial Fund Quarterly/Health and Society 1982;60:429-62.

HODGSON TA. The state of the art of cost-of-illness estimates. Advances in Health Economics and Health Services Research 1983;4:129-64.

TEN HOOPEN AJ, BOERMA JT, CLAY W. Verlies aan levensjaren (in Dutch, with summary in Eng(ish). Tijdschrift Sociale Geneeskunde 1982;60:125-33.

ILLSLEY R. Social equity and health in Europe. T Soc Gezondheidsz 1988;66:310-4.

KATZ S, BRANCH LS, BRANSON MH et al. Active life expectancy. N Engl J Med 1983;309:121824 .

KUNST AE, LOOMAN CWN, MACKENBACH JP. SOcio-economic mortality differences in the Netherlands in 1950-1984: a regional study of cause-specific mortality. Soc Sci Med $1990 ; 31: 141-52$.

van der MAAS PJ, hOFMAN A, DEKKER E (eds.). Epidemiologie en gezondheidsbeleid (in Dutch). Alphen aan den Rijn (the Netherlands): Samsom Stafleu, 1989.

MacGINNIS JM. Targeting progress in health. Public Health Reports 1982;97:295-307.

MacGINNIS JM. Setting nationwide objectives in disease prevention and health promotion: the United States experience. In: Holland HH, Detels R, Knox G (eds). Oxford textbook of public health, volume 3. Oxford: Oxford University Press, 1985.

MACKENBACH JP, LOOMAN CWN, KUNST AE. Regionale doodsoorzaakprofielen (in Dutch, with summary in English). T Soc Gezondheidsz 1990;68:57-66.

MacWHINNIE JR. Disability assessment in population surveys: results of the OECD common development effort. Rev Epidém et Santé Publ 1981;29:413-9.

MARMOT MG. Social class and mortality. T Soc Gezondheidsz 1988;66:315-20.

MINISTRY OF WELFARE, HEALTH AND CULTURAL AFFAIRS. Health for all by the year 2000; rapportage Nederland 1988 (in Dutch). Rijswijk (the Netherlands): Ministerie van WVC, 1988. 
ministry OF melfare, health and cultural afFairs. Policy document on cancer control. Rijswijk (the Netherlands): Ministerie van wVC, 1989.

MÖLKEN MPMH. CARA in cijfers (in Dutch). Maastricht (the Netherlands): Institute of Technology Assessment, 1989.

MOOTZ M. Health indicators. Soc Sci Med 1986;22:255-63.

MUIR C, waterhouse J, MACK T, PONELL J, MHELAN $s$ (eds). Cancer incidence in five continents, vol.V. Lyon: International Agency for Research on Cancer, 1987:574-9. (IARC Scientific Publications no.88).

NATIONAL CENTER FOR heALTH STATISTICS. Health United States 1989 and Prevention Profile. Hyattsville, Maryland: Public Health Service, 1990; DHHS publ.no.(PHS)90-1232.

OECD. Measuring health care, 1960-1983. Paris: OECD, 1985. (Social Policy Studies no.2).

OWENS JF, MATTHEWS KA, HING RR, KULLER LH. Physical activity and cardiovascular risk: a cross-sectional study of middle-aged premenopausal women. Preventive Medicine 1990; 19: 147-57

PELLETIER L. Health indicators and public health planning (in French, with summary in English). Rev Epidén et Santé Publ 1990;38:47-56.

RICE DP. Estimating the cost of illness. Washington: U.S. Public Health Service, 1966. (Health Economics Series no.6).

RICE DP, HODGSON TA, KOPSTEIN AN. The economic cost of illness; replication and update. Health Care Financing Review 1985; 7:61-90.

ROBINE JM, BROUARD N, COLVEZ A. Les indicateurs d'espérance de vie sans incapacité (EVSI); des indicateurs globaux de l'état de santé des populations (in French, with summary in English). Rev Epidém et Santé Publ 1987;35:206-24.

ROBINE JM. Estimation de la valeur de ('espérance de vie sans incapacité (EVSI) pour les pays occidentaux au cours de la dernière décennie. Quelle peut être l'utilité de ce nouvel indicateur de l'état de santé? Wld $\mathrm{H}$ th Statist Quart 1989;42:141-8.

ROBINE JM, BLANCHET M. Proceedings of the first workshop on international geographic comparisons of healthy life expectancy 1989. Montpellier (France): INSERM, 1990.

ROMEDER JM, MCNHINNIE JR. Potential years of life lost between ages 1 and 70 as an indicator of premature mortality. Intern J Epidemiol 1977;6:143-51.

ROSEN M, NYSTROM L, WALL S. Guidelines for regional mortality analysis: an epidemiological approach to health planning. Intern J Epidemiol 1985;14:293-9.

SCHWEFEL D (ed). Indicators and trends in health and health care. Berlin: Springer Verlag, 1987.

SHAPER AG, PHILLIPS AN, HALKER M. Alcohol and ischaemic heart disease in middle aged Bri$t$ ish men. Br Med J 1987;294:733-7.

SHEPHARD RJ. The value of physical $f i t n e s s$ in preventive medicine. In: the value of preventive medicine (Ciba Foundation symposium 110). London: Pitman, 1985: 164-82.

STG (Dutch Steering Committee on Future Health Scenarios). The heart of the future - the future of the heart. Dordrecht (the Netherlands): Kluwer Academic Publishers, 1987.

STG. Chronische ziekten in het jaar 2005. Vol.1, scenario's over diabetes mellitus (in Dutch). Utrecht (the Netherlands): Bohn, Scheltema \& Holkema, 1990a. 
STG. Zorgen voor geestelijke gezondheid in de toekonst (in Dutch). Utrecht (the Netherlands): Bohn, Schelteme \& Holkema, 1990b.

SULLIVAN DF. Disability components for an index of health. Washington: U.S. Government Printing office, 1971a. (PHS Publication no.1000, Series 2 no.42).

SULLIVAN DF. A single index of mortality and morbidity. HSMH Health Reports 1971b;86:34754.

SVENSSON PG. Disadvantaged groups: a challenge for health services.

T Soc Gezondheidsz 1988;66:307-9.

United States department of health AND human SERvices. Health Care financing Review; 1989 Annuel Supplement. Beltimore: DHSS, 1989.

van der VELDEN J, de BAKKER DH, CLAESSENS AAMC, SCHELlevis FG. Nationale studie van ziekten en verrichtingen in de huisartspraktijk. Basisrapport morbiditeit (in Dutch). Utrecht (the Netherlands): NIVEL, 1990.

VERKDOIJEN JM, BREEVOORT ELMG, AMENT AJHA. Kosten van hart- en vaatziekten voor Nederlandse bedrijven (in Dutch). Maastricht (the Netherlands): Limburg State University, 1989.

VERKOOIJEN JM, AMENT AJHA, BREEVOORT ELMG. Kosten van hart- en vaatziekten in Nederland. Maastricht (the Netherlands): Limburg State University, 1990.

WALL S, ROSEN M, NYSTROM L. The Swedish mortality pattern: a basis for health planning? Intern J Epidemiol 1985; 14:285-92.

van de WATER HPA. Bouwen aan basisgezondheidszorg (in Dutch, with summary in English). Leiden (the Netherlands): NIPG-TNO, 1989.

WIGGERS CCMC, BERGSMA EW. De kosten van AIDS/HIV in Nederland: een inventarisatie (in Dutch, with summary in English). Leiden (the Netherlends): NIPG-TNO, 1990.

WILKINS R, ADAMS 0 . Healthfulness of life. Montreal: The Institute of Research on Public Policy, 1983.

WILSON RH, DRURY TF. Interpreting trends in illness and disability: health statistics and health status. Ann Rev Public Health 1984;5:83-106.

WINKLEBY MA, FORTMANN SP, BARRETT DC. Social class disparities in risk factors for disease: eight-year prevalence patterns by level of education. Preventive Medicine 1990; 19:1-12.

ZWICK DI. Establishing national health goals and standards. Public Health Reports $1983 ; 98: 416-25$. 


\section{HEALTH BENEFITS AND COSTS OF PREVENTION}

\subsection{Introduction}

The aim of preventive health care is to prevent or postpone morbidity and premature mortality. Prevention therefore involves both the quality and quantity of life. Usually a distinction is made between primary, secondary and tertiary prevention.

Primary prevention means that new cases of a disease are really prevented and do not occur, because the cause(s) of that disease has (have) been eliminated.

Primary prevention is only feasible if the causes (determinants, risk factors, risk indicators) of certain forms of morbidity and premature mortality are known and can be tackled. Therefore, lung cancer is suitable for primary prevention and breast cancer is not (Prentice et al 1988; Zelen 1988). Well-known methods of primary prevention are health education - e.g. against smoking and unsafe sexual practices, hygiene - e.g. safe drinking water and adequate sewage disposal, malaria prophylaxis and vaccination. Primary prevention of ten calls for intersectoral cooperation, i.e. participation of other sectors such as finance, agriculture, transport, social welfare, employment, environment, etc. Intersectoral cooperation in prevention is essential if health objectives such as less smoking, better nutrition or fewer accidents are to be achieved; this aspect does not, however, fall within the scope of this report.

Secondary prevention is the detection and treatment of a disease before the "patient" becomes aware of it, thereby preventing the disease from becoming manifest. Well-known examples are (mass) screening for phenylketonuria, hypercholesterolaemia or breast cancer and the periodic examination of school children or workers in certain occupations.

Tertiary prevention is not really a form of disease prevention; it is instead an attempt to limit the damage caused by manifest disease and to mitigate its ef fects. Tertiary prevention focusses especially on preventing permanent invalidity, 
e.g. after an injury or due to chronic diseases. It can also be considered a form of curative care.

Basically, preventive and curative care have the same objective: health benefit (also called health gain), i.e. decreasing the amount of disease and disability and/or postponing death. There are important differences, however:

- whereas a patient will ask for curative treatment himself, preventive health care is usually offered actively to people who feel healthy and therefore carries the risk of "medicalization". Prevention programmes therefore have to be planned even more carefully than curative measures because, in addition to health benefit, prevention also has a price tag (Skrabanek 1986). Since this is especially true for mass screening (Eddy 1986; Mant and Fowler 1990), special rules have been drawn up for this type of prevention (Wilson and Jungner 1968). The aim of screening programmes is that everyone will be examined and many will be treated for preclinical disease or elevated risk. If the test and the preventive measure are not burdensome, this is more acceptable than if the intervention consists of, for instance, a life-long dietary or - even worse - drug regimen.

- the effects of prevention are not immediately noticeable and cannot be guaranteed for everyone participating in the prevention programme. Prevention offers "treatment" on the basis of a statistical risk for future disease and not for an existing health problem. The economic implications of these effects will be discussed in $\S 3.6$ and 3.7.

- although prevention is also offered to individuals, as curative care always is, it usually is aimed at groups in the population.

\subsection{How can gains in health be measured?}

In principle, health gained through prevention becomes manifest as an improvement in (at least) one of the indicators discussed in chapter 2, with the same restriction regarding the difference between groups of indicators of morbidity. 
To be able to attribute health gains to a specific preventive measure, however, the demonstration of a change in one indicator will be more feasible than the use of another indicator.

The influence of a preventive measure on the total age-adiusted mortality rate for a population usually cannot be demonstrated, because no such intervention has a sufficiently large impact on this indicator in a limited period of time, not even a vast offensive against a major health problem such as lung cancer or myocardial infarctions.

On the other hand, a decrease in the disease-specific mortality rate is of ten used as a yardstick for the success of a preventive measure, e.g. primary prevention of lung cancer or accidents and secondary prevention of cardiovascular disease, breast cancer or maternal deaths.

Critics point out that a decrease in disease-specific mortality without a decrease in total mortality only means a shift from one cause of death to another. This will be discussed in chapter 6 .

Sometimes a reduction in the age-specific mortality rate is used as a measure of health gained: for instance, the infant mortality rate, especially in developing countries.

As in the case of the total mortality rate, one can hardly expect to demonstrate that an increase in life expectancy at birth (= the average number of life vears gained) was caused by a preventive measure in a population, because no single intervention will have a sufficiently large impact to cause a visible change in this indicator. However, as a theoretical exercise one can calculate the increase in life expectancy if a cause of death were to be completely eradicated. This is described in $\S 3.3$.

There are two ways to visualize an otherwise undetectable increase in the life expectancy of the total population caused by a preventive measure.

The first is to calculate the average number of life vears gained bv the saved population, i.e. those who would have died of the disease without the intervention. This number is, of course, much higher than the average number for the total population (see $\S 3.3$ ). 
The second method is to calculate the total number of life years gained within a population as a result of a preventive measure by adding up all of the years gained during the intervention period by all persons who would otherwise have died. This again leads to a sizeable figure, even if only a small percentage of the population benefits from the intervention.

It is possible and even desirable to correct the number of life years gained for the quality of those years. It makes quite a difference whether the years gained are spent in bed or as an active person. Therefore each year can and should be adjusted for quality by a factor between 0 and 1 ; in this way the gain can be expressed as the number of quality-adiusted life vears ("QALYs"). QALYs represent a combination of a mortality-derived measurement and a state of morbidity, as in the case of health expectancy; however, unlike the latter QALYs are used for specific preventive and curative actions. There is considerable literature on this controversial indicator of health benefit (Smith 1987; La Puma and Lawlor 1990); for more information see the references. In this report, it will be discussed again briefly in $\S 3.6 .2$.

One of the most logical outcomes of successful preventive measures against a certain disease is a decrease in the incidence rate for that disease. This is the usual indicator of prevention of non-lethal diseases, e.g. infectious diseases or congenital malformations, but it can also be used for diseases that can be lethal, such as various types of cancer or cardiovascular disease. In figure 3.1, the influence of the introduction of poliomyelitis vaccine in 1957 on the incidence of that disease in the Netherlands can be seen.

As described in chapter 2, the frequency of acute diseases in a population is usually given by incidence rates, while the frequency of chronic or permanent conditions, which begin insidiously, is indicated by prevalence rates. The prevalence of chronic conditions is somewhat arbitrary because generally the onset is not clear and the demarcation between healthy and sick is not well-defined. Moreover, these conditions of ten have multiple or unknown origins. Therefore a decrease in the prevalence rate of such diseases is not a very reliable indicator of the success of preventive measures against them. 
Fiqure 3.1 Incidence of reported cases of poliomyelitis (paralytic and non-paralytic) per 100,000 of population in the Netherlands, 1950-1979.

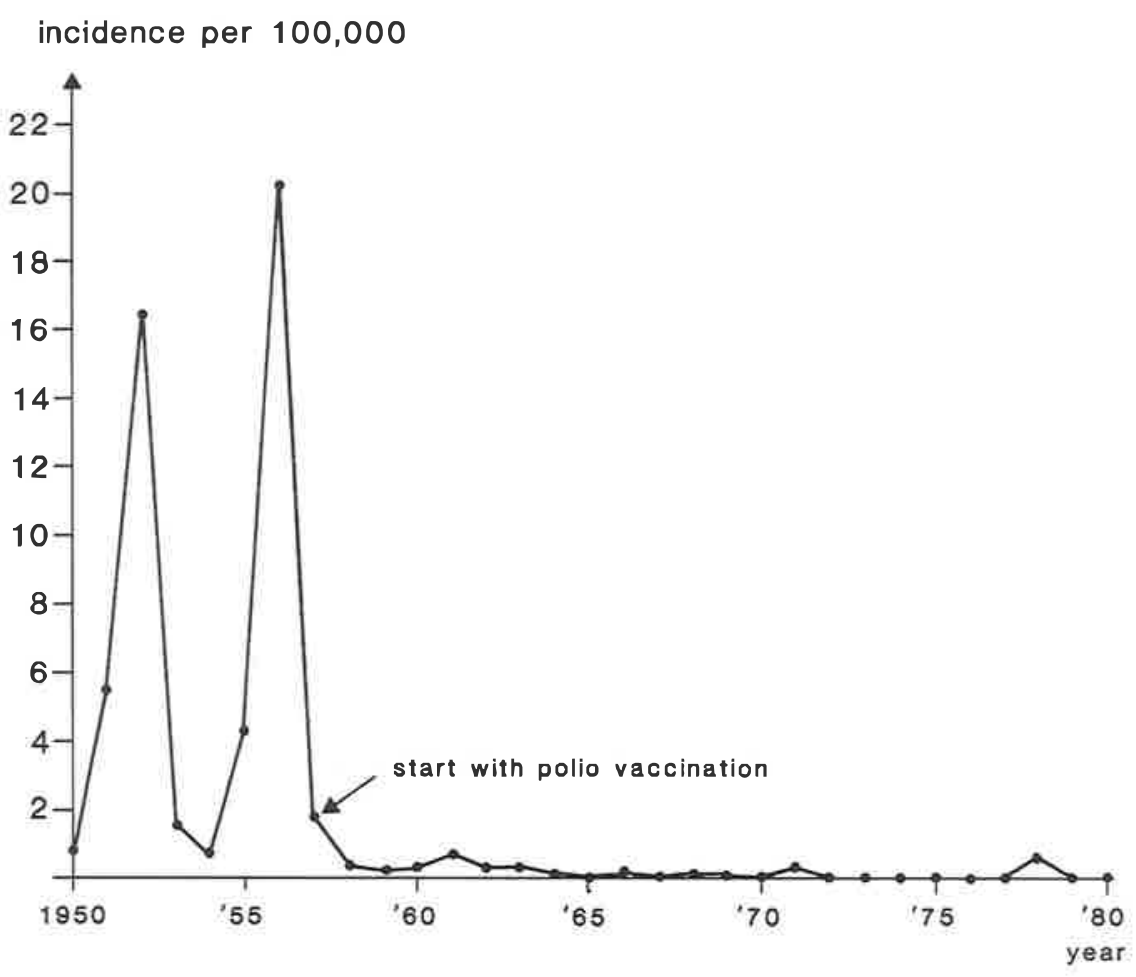

Source: Bijkerk 1982

An improvement in the self-rated health status is too general to be a suitable indicator of the effectiveness of a prevention programme and is therefore not being used as such.

The same applies for a decrease in the demand for health care. However, in some cases a decrease in the demand for specific forms of health care can be the logical outcome of a preventive intervention. A successful antenatal screening programme for Down's syndrome will eventually lead to the closing of some institu- 
tions for the mentally handicapped, and dentists are making themselves partially superfluous by the effective prevention of dental caries. Originally, one of the motives behind prevention was to decrease the demand for health care, thereby saving money. We now know that generally this is not the case (see also $\S 3.6$ ) but as we shall see, in rare instances it can happen.

A decrease in sickness absenteeism and work disability could also be considered the result of preventive measures. Such measures have indeed been introduced by occupational health care, but evaluation is difficult because the main causes of work absenteeism and work disability (musculoskeletal and mental problems) are multifactorial and sometimes are not connected directly with the work site or the jobs performed. Good results have been achieved in some specific areas where cause and effect are clearly related, such as prevention of hearing loss, silicosis and occupational cancers.

One of the indicators most of ten used for evaluating the effectiveness of prevention programmes is the decrease in the prevalence of determinants of specific diseases; in fact, this is only an indirect measure that does not always correspond to a decrease in morbidity in the population. Determinants that are being monitored continuously and intensively in the Netherlands are, for example, smoking prevalence (shown in figure 2.5), alcohol consumption and environmental pollution. Other risk indicators are examined from time to time in various regions or subgroups of the population, such as sexual behaviour, hypertension or serum cholesterol level.

Active life expectancy is arguably the best indicator of (an improvement in) the overall health status of a population, but an increase in active life expectancy cannot be used to demonstrate the effectiveness of a preventive measure, because there are too many variables, too many confounders and too many unknown factors.

In conclusion it can be stated that many indicators of health gained by prevention exist: some are better than the others, some are suitable for specific interventions only and some apply for theoretical exercises only. The ones most commonly used are (disease-specific) mortality rates, total number of life years 
gained in a population, incidence rates and prevalence of risk indicators. In this report, the theoretical exercise of calculating the number of life years gained by elimination of some causes of death will be discussed separately (in $\S 3.3$ ) because this was a topic of recent research carried out by NIPG-TNO.

\subsection{Gains in life expectancy achieved by eliminating a cause of death}

The calculation of the gains in life expectancy due to elimination of a cause of death is a theoretical exercise, because the main causes of death in the developed world cannot be eliminated. Cardiovascular disease and cancer are more or less "normal" causes of death that can at the most only be partially eliminated. The purpose of the exercise is that, as one of the methods described in $\S 3.2$, it visualizes the potential impact of prevention programmes, thereby incorporating a rough estimate of the order of magnitude of the replacement of one cause of death by others. It cannot serve as a method for evaluating the actual impact of these prevention programmes.

The subject has been described in more detail in one of the reports of the NIPG "Prevention Profiles" project (van Ginneken et al 1989). There one can also find the calculations made to arrive at the results presented here, together with references to similar work in the United States.

It is obvious that the gain in life expectancy due to the elimination of a cause of death is determined by the magnitude of the health problem that is being eliminated as well as the average age at which people die of that health problem. The elimination of a rare disease will hardly affect the average life expectancy of the population nor will the elimination of a disease that is only fatal after the age of 80 .

It makes a difference whether the probabilities of dying of certain causes are independent of one another or not. Although it is quite possible that people who run a higher risk of developing cancer than the average population are also at increased risk for cardiovascular disease (or the reverse), calculation of the increase in life expectancy due to eliminating a cause of death is usually based on independent risks. If the chance of dying of cancer is somehow positively associ- 
ated with the chance to die of cardiovascular disease, then the elimination of cancer will result in a smaller increase in life expectancy than expected. On the contrary, other assumptions about the dependency between causes of death (through common risk factors or otherwise) may lead to better results from the elimination of one cause of death than in the case of independent causes. The literature is not clear on the difference between "competition" and "replacement" of causes of death. Here only independent risks will be considered, because models incorporating interactions of causes of death are not yet available.

It also makes a difference whether the gain in life expectancy is calculated for the total population or only that proportion of the population that is "saved" by eliminating that cause of death, i.e. those who will not die of that specific cause. Since our mortality pattern is dominated by typical old-age causes, such as cardiovascular disease and cancer, the elimination of one cause will quickly lead to an exponential increase in the risks for other causes, and the gain in life expectancy for the total population will be remarkably limited. This does not apply for the saved population, however, especially when a less common cause of death or a cause that frequently occurs at a younger age is eliminated.

Table 3.1 shows the gains in life expectancy for the total population at various ages if any one of four groups of causes of death could be eliminated. As can be expected, elimination of cardiovascular disease would produce the greatest benefit, followed by cancer. Gains are less for females than for males, because the female mortality rates are lower than male mortality rates in each of the four categories. 
Table 3.1 Gains in life expectancy (in years) due to elimination of four groups of causes of death for the total Dutch population, 1981-1985

\begin{tabular}{|c|c|c|c|c|}
\hline \multirow[b]{2}{*}{ Age } & \multicolumn{4}{|c|}{ MEN } \\
\hline & Cancer & $\begin{array}{l}\text { Cardiovascular } \\
\text { disease }\end{array}$ & $\begin{array}{l}\text { External } \\
\text { causes }\end{array}$ & $\begin{array}{l}\text { All other } \\
\text { causes }\end{array}$ \\
\hline 0 & 3.79 & 5.95 & 1.04 & 3.09 \\
\hline 5 & 3.81 & 6.01 & 0.98 & 2.36 \\
\hline 15 & 3.79 & 6.02 & 0.90 & 2.30 \\
\hline 25 & 3.77 & 6.04 & 0.66 & 2.23 \\
\hline 35 & 3.74 & 6.03 & 0.48 & 2.15 \\
\hline 45 & 3.65 & 5.95 & 0.34 & 2.05 \\
\hline 55 & 3.35 & 5.61 & 0.23 & 1.93 \\
\hline 65 & 2.65 & 4.95 & 0.16 & 1.79 \\
\hline 75 & 1.61 & 3.96 & 0.13 & 1.63 \\
\hline \multirow[t]{2}{*}{85} & 0.71 & 2.74 & 0.11 & 1.41 \\
\hline & \multicolumn{4}{|c|}{ WOMEN } \\
\hline Age & Cancer & $\begin{array}{l}\text { Cardiovascular } \\
\text { disease }\end{array}$ & $\begin{array}{l}\text { External } \\
\text { causes }\end{array}$ & $\begin{array}{l}\text { All other } \\
\text { causes }\end{array}$ \\
\hline 0 & 3.24 & 5.67 & 0.65 & 3.02 \\
\hline 5 & 3.25 & 5.71 & 0.61 & 2.38 \\
\hline 15 & 3.23 & 5.72 & 0.56 & 2.33 \\
\hline 25 & 3.20 & 5.72 & 0.48 & 2.28 \\
\hline 35 & 3.15 & 5.72 & 0.40 & 2.22 \\
\hline 45 & 2.95 & 5.70 & 0.33 & 2.16 \\
\hline 55 & 2.49 & 5.65 & 0.27 & 2.07 \\
\hline 65 & 1.82 & 5.47 & 0.22 & 1.94 \\
\hline 75 & 1.12 & 4.82 & 0.18 & 1.75 \\
\hline 85 & 0.53 & 3.40 & 0.15 & 1.48 \\
\hline
\end{tabular}

Source: van Ginneken et al 1989 
Table 3.2 Gains in (ife expectency (in years) due to elimination of four groups of causes of death for the saved Dutch population, 1981-1985

\begin{tabular}{|c|c|c|c|c|}
\hline \multirow[b]{2}{*}{ Age } & \multicolumn{4}{|c|}{ MEN } \\
\hline & Cancer & $\begin{array}{l}\text { Cardiovascular } \\
\text { disease }\end{array}$ & $\begin{array}{l}\text { External } \\
\text { causes }\end{array}$ & $\begin{array}{l}\text { All other } \\
\text { causes }\end{array}$ \\
\hline 0 & 13.03 & 13.36 & 24.49 & 13.99 \\
\hline 5 & 13.01 & 13.34 & 23.31 & 11.07 \\
\hline 15 & 12.86 & 13.32 & 22.05 & 10.81 \\
\hline 25 & 12.75 & 13.29 & 18.02 & 10.47 \\
\hline 35 & 12.60 & 13.22 & 14.55 & 10.13 \\
\hline 45 & 12.25 & 12.93 & 11.70 & 9.67 \\
\hline 55 & 11.30 & 12.12 & 9.01 & 8.97 \\
\hline 65 & 9.38 & 10.57 & 6.81 & 7.91 \\
\hline 75 & 6.65 & 8.31 & 5.06 & 6.38 \\
\hline 85 & 3.92 & 5.71 & 3.39 & 4.54 \\
\hline \multicolumn{5}{|c|}{ WOMEN } \\
\hline Age & Cancer & $\begin{array}{l}\text { Cardiovascular } \\
\text { disease }\end{array}$ & $\begin{array}{l}\text { External } \\
\text { causes }\end{array}$ & $\begin{array}{l}\text { All other } \\
\text { causes }\end{array}$ \\
\hline 0 & 14.46 & 11.67 & 16.49 & 12.06 \\
\hline 5 & 14.38 & 11.65 & 15.40 & 9.75 \\
\hline 15 & 14.28 & 11.65 & 14.49 & 9.56 \\
\hline 25 & 14.16 & 11.62 & 12.69 & 9.36 \\
\hline 35 & 13.93 & 11.56 & 11.04 & 9.12 \\
\hline 45 & 13.22 & 11.45 & 9.54 & 8.84 \\
\hline 55 & 11.69 & 11.15 & 7.97 & 8.39 \\
\hline 65 & 9.41 & 10.50 & 6.61 & 7.67 \\
\hline 75 & 6.79 & 9.02 & 5.24 & 6.55 \\
\hline 85 & 4.06 & 6.47 & 3.76 & 4.84 \\
\hline
\end{tabular}

Source: van Gīnneken et al 1989 
Table 3.2 shows the gains in life expectancy for the "saved" population, i.e. those who otherwise would have died of a particular disease. Of course, they will die later of one of the other three general causes. The gains for the saved population are much more impressive in all four categories; elimination of external causes (injuries etc.) would yield the greatest benefit. For younger females, cancer takes precedence over cardiovascular disease.

In table 3.3, both ways of presenting gains in life expectancy are shown again, this time for some smaller specific health problems. The differences are even greater.

Table 3.3 Gains in (ife expectancy at birth (in years) due to elimination of some specific health problems: total versus saved Dutch male and female populations, $1981-1985$

\begin{tabular}{lcc}
\hline elimination of: & total male & saved male \\
population & 0.1 & 13.6 \\
\hline infectious and parasitic diseases & 0.2 & 7.4 \\
carcinoma of the prostate & 0.3 & 61.2 \\
congenital diseases & 0.3 & 24.6 \\
suicide & total female & saved female \\
\hline & population & population \\
elimination of: & 0.1 & 16.0 \\
\hline breast cancer & 0.1 & 17.7 \\
carcinoma of the cervix & & 51.7 \\
complications of pregnancy, & 0.0 & \\
childbirth and puerperium & & \\
\hline
\end{tabular}

Source: van Ginneken et al 1989

The conclusion is that from the point of view of a population a prevention strategy against cardiovascular disease and cancer would be preferable, whereas the individual will benefit more from a strategy for the prevention of accidents and specific diseases that occur earlier in life. It has to be kept in mind, however, that this is a theoretical exercise that cannot be executed in real life, because most health problems cannot be eradicated like smallpox. 


\subsection{Models for assessing the health benefits of prevention}

A model is a system of elements and the relationships between these elements that is a simplified representation of a real situation. Its purpose is to obtain a better understanding of what is happening in reality and how we can influence the underlying processes.

The Lalonde model, described in chapter 1 , is a simple qualitative (conceptual) model that formed the basis for so-called health policy, i.e. the shift away from the planning of health care facilities towards plans for better health by focussing upon the determinants of health.

Using quantitative (mathematical) models that incorporate determinants, health and health care, one can try to predict the effect of various (preventive or curative) measures on the health status of the population. In this way, the models are used as a tool for planning health policy.

The proportion of the incidence of a health problem that can be ascribed to a certain determinant is called the attributable risk. For example, the attributable risk of smoking for lung cancer is approximately $90 \%$. The attributable risk can also be explained as the maximum proportion of a health problem that can be prevented by elimination of that determinant.

The degree of association between a risk indicator (determinant) and a disease is called the relative risk, meaning the ratio of the incidence rate for those who have the risk indicator to the incidence rate for those who do not. For example, if the relative risk of lung cancer for non-smokers is defined as 1 , then the relative risk of lung cancer for those who smoke half a packet of cigarettes per day will be approximately 7. A low relative risk ( e.g. 1.5 or 2) means a weak association between the risk factor and the disease, while a relative risk between 0 and 1 means that the risk factor actually protects against the disease.

Attributable and relative risks are elements of the models described below.

It has to be kept in mind that specific preventive measures - e.g. those dealing with smoking, alcohol and nutrition - may have an influence on several health problems, and that a health problem may be associated with various determinants at the same time. 
Generally speaking, a determinant cannot be eliminated completely but only partially, and therefore the health gain will be less than that indicated by the attributable risk. The proportion of the health problem that can be prevented by means of realistic preventive activities is called the (potential) impact fraction (Morgenstern and Bursic, 1982).

Often, the potential impact of a prevention programme is quantified as a decrease in incidence or the number of life years gained. In some models this number is adjusted for the quality of those years. Sometimes not only the effects of preventive measures are calculated but also the costs, financial and otherwise, which of course makes such models more suitable for health planning.

Many complications arise when one tries to construct a mathematical health policy model. Much ill-health cannot yet be explained by determinants. A wealth of epidemiological data - relative risks, distribution of risk factors in the population, etc. - is needed but the information of ten is not routinely available or conflicting results are obtained. Therefore, (too) many assumptions have to be made. Some determinants influence several different health problems simultaneously. Many health problems are associated with more than one risk factor. The participation of the population in the proposed prevention programmes has to be incorporated into the model. Populations are not homogeneous and have to be stratified for age, sex, race and other characteristics. These characteristics will change during the long latency periods that usually precede a noticeable impact of prevention programmes on the health status. The consequences of competing causes of death are usually not taken into account (see chapter 6). And so on.

One can only admire the perseverance with which so many scientists continue to work on these models. In the past, several attempts have been made to construct specific models for the control of infectious diseases (Bailey 1975). The implementation of a major malaria eradication programme on the basis of such a model proved to be a failure (Molineaux and Gramiccia 1980). At present, a lot of energy is being spent on models for the HIV epidemic, with mixed results (Jager et al 1989). Recently, models were made specifically for cancer (WHO 1986), cardiovascular disease (STG 1987; Weinstein et al 1987; Taylor et al 1987; Martens et al 1989), breast cancer (van der Maas et al 1989) and cervical cancer 
(Koopmanschap et al 1990). Some of the typical cost-effectiveness studies used for specific health problems will be discussed in $\$ 3.7$. A few publications on more general models are described briefly below.

Morgenstern and Bursic (1982) constructed a relatively simple model along the above-mentioned lines of risk factor distribution, relative risks, attributable risk and potential impact fraction. The outcome of preventive measures is given as a decrease in incidence. They used the impact of a weight reduction programme on the incidence of coronary heart disease as an example.

Kaplan and Anderson (1988) described a more complicated "general health policy model" with strong emphasis on the quality of the life years gained. They called these quality-adjusted life years "well-years". Many aspects of quality were taken into account. They presented some examples of the practical application of the model, such as various screening procedures and a programme of tertiary prevention for chronic obstructive pulmonary disease. They also took the financial costs into account.

MISCAN is a computer programme of a model for secondary prevention programmes, developed by the Department of Public Health and Social Medicine at the Erasmus University of Rotterdam, the Netherlands (Habbema et al 1984; Habbema et al 1987). It can simulate both the natural epidemiology of the disease and the results of screening for that disease and includes full cost-effectiveness calculations. Some of the results will be described in $\S 3.7$.

Gunning-Schepers (1988) constructed the "Prevent" model, which is based more or less on the concepts of Morgenstern and Bursic but the effects of prevention are given as the reduction in mortality. The model incorporates three extra features: a) the possibility that one risk factor affects several diseases and that one disease is affected by several risk factors; b) a time dimension to simulate the reduction in excess risk after cessation of exposure to the risk factor; and c) the interaction between the effect of the intervention and the demographic evolution of the population. She applied the model to known determinants of major health problems. The greatest health benefits can be expected from a reduction in the prevalence of smoking. 
Bannenberg and van Ginneken (1989) also studied the impact of preventive measures on mortality. They also used the impact fraction concept and included demographic evolution, but their model is simple without some of the refinements of the "Prevent" model and without a cost component. The model was used to calculate the potential impact on various health problems of alternative prevention scenarios: screening for breast cancer, cervical cancer and hypertension, and policies against smoking and alcohol abuse. For the population, an anti-smoking policy is the most effective preventive programme for both males and females; however, for the individual - i.e. those whose lives will be saved by the programme - screening for hypertension has a greater impact among males and screening for breast cancer among females.

It is difficult to summarize the usefulness of health policy models. As tools for understanding the feasibility of preventive and curative measures they are unsurpassed but not widely used. They often inspire fear, rejection or indifference in policymakers without mathematical expertise. They have sometimes proven to be far off the mark when tested with existing data, either historical data or those collected after the actual implementation of a preventive measure, which makes them vulnerable to criticism.

It would seem wise not to claim that the future can be predicted with the help of mathematical models or to produce too many precise figures and graphs. The strength of these models lies in their ability to reveal underlying mechanisms and provide global estimates of the costs and effects of alternative policy options. Reports based on these models should be written in plain language, with most of the calculations in appendices, to enable the reader to understand the assumptions and offer constructive criticism. For realistic planning purposes, it is better to rely upon the results of community trials and "natural experiments" rather than calculations based on health policy models.

Somehow the concept of competing causes of death has to be incorporated into health policy models in the future. This subject will be discussed in chapter 6 . 
The preventability of health problems is judged by the effectiveness and efficiency of the appropriate preventive methods. Effectiveness indicates the health benefit resulting from a preventive action, and efficiency is the relationship between this result and the price that had to be paid for it (see $\$ 7.3$ ).

Many preventive measures now in progress are assumed to have sufficient effectiveness and efficiency although this has not been proven. Some programmes have been discontinued because of lack of effectiveness, e.g. mass screening for lung cancer, or because they have become inefficient, e.g. mass screening for tuberculosis.

Prevention programmes may prove to be less effective in practice than in theory. Participation of the population can be disappointing or organizational difficulties might affect the outcome unfavourably. If tobacco or alcohol were no longer available, lung cancer or alcohol-related morbidity and mortality would cease to be a health problem. However, even an outright ban on these articles - not a realistic proposition politically - would be circumvented, as seen in the past during prohibition. Changes in life style or participation in screening programmes will never be accepted by $100 \%$ of the population. This distinction between theoretical preventability ( $\approx$ efficacy) and practical preventability ( $\approx$ effectiveness) shall be discussed further in chapter 7 .

Ideally, prevention programmes should be based on the results of epidemiological research and cost-effectiveness or cost-benefit analyses. A lot of work has already been done in this field and research is in progress (see $\S 3.6$ and 3.7). Screening programmes, moreover, have to satisfy the specific requirements established (Wilson and Jungner 1968).

Several investigators have studied the geographical and time patterns of avoidable mortality, i.e. mortality amenable to both curative and preventive action (Holland 1986; Charlton and Velez 1986; Gunning and Hagen 1987; CarrHill et al 1987; Junge and Thom 1987; Mackenbach 1988; Silman and Allwright 1988). Some of these studies have been reviewed (Mackenbach et al 1990). 
Table 3.4 Existing and proposed prevention programes for a number of health problems

\begin{tabular}{|c|c|c|}
\hline & primary prevention & secondery prevention \\
\hline - cardiovascular disease & $\begin{array}{l}\text { - antismoking policy } \\
\text { - nutrition (salt, fat, } \\
\text { cholesterol, obesity) } \\
\text { - physical exercise }\end{array}$ & $\begin{array}{l}\text { - cholesterol screening + drug } \\
\text { treatment } \\
\text { - hypertension screening + drug } \\
\text { treatment }\end{array}$ \\
\hline - lung cencer & - antismoking policy & \\
\hline - breast cancer & & - mess screening \\
\hline - cervical cancer & & - mass screening \\
\hline - prostate cancer & & - screening? \\
\hline $\begin{array}{l}\text { - skin cancer + melanoma } \\
\text { - colon cancer }\end{array}$ & - avoiding UV & $\begin{array}{l}\text { - screening? } \\
\text { - screening? }\end{array}$ \\
\hline - occupational cancers & - industrial hygiene & - periodic examination \\
\hline $\begin{array}{l}\text { - sexually transmitted } \\
\text { diseases }\end{array}$ & $\begin{array}{l}\text { - "safe sex" } \\
\text { - periodic examination } \\
\text { prostitutes? }\end{array}$ & - lues test in pregnancy \\
\hline - AIDS & $\begin{array}{l}\text { - "safe sex" } \\
\text { - safe blood supply } \\
\text { - clean needles }\end{array}$ & \\
\hline - other infectious diseases & $\begin{array}{l}\text { - hygiene } \\
\text { - vaccination }\end{array}$ & $\begin{array}{l}\text { - screening for carriers } \\
\text { - quarantaine }\end{array}$ \\
\hline $\begin{array}{l}\text { - phenylketonuria } \\
\text { - congenital hypothyroidism }\end{array}$ & & $\begin{array}{l}\text { - mass screening } \\
\text { - mass screening }\end{array}$ \\
\hline - other congenital diseases & $\begin{array}{l}\text { - ovoiding teratogenic } \\
\text { influences }\end{array}$ & - screening \\
\hline - hereditary díseases & - genetic counseling & - genetic testing + abortion \\
\hline - dental caries & $\begin{array}{l}\text { - dental hygiene } \\
\text { - fluoride } \\
\text { - diet (sugars) }\end{array}$ & - periodic examination \\
\hline - unwanted pregnancy & - contraception & - abortion \\
\hline $\begin{array}{l}\text { - problems in pregnancy, } \\
\text { childbirth and puerperium }\end{array}$ & $\begin{array}{l}\text { - health education } \\
\text { - life style }\end{array}$ & - periodic examination \\
\hline $\begin{array}{l}\text { - various childhood } \\
\text { development problems }\end{array}$ & $\begin{array}{l}\text { - health education } \\
\text { - Life style }\end{array}$ & $\begin{array}{l}\text { - pre-school clinics } \\
\text { - school health programmes }\end{array}$ \\
\hline $\begin{array}{l}\text { - chronic obstructive } \\
\text { lung disease }\end{array}$ & $\begin{array}{l}\text { - antismoking policy } \\
\text { - air pollution control? }\end{array}$ & \\
\hline
\end{tabular}


Iable 3.4 (continued)

\begin{tabular}{|c|c|c|}
\hline & primary prevention & secundary prevention \\
\hline - injuries & $\begin{array}{l}\text { - health education } \\
\text { - life style } \\
\text { - road safety } \\
\text { - industrial safety }\end{array}$ & \\
\hline $\begin{array}{l}\text { - psychiatry, suicide } \\
\text { - drug abuse } \\
\text { - alcohol abuse }\end{array}$ & $\begin{array}{l}\text { - mental heal th programes? } \\
\text { - antidrug policy } \\
\text { - antialcohol policy }\end{array}$ & \\
\hline $\begin{array}{l}\text { - environmental health } \\
\text { problems? }\end{array}$ & $\begin{array}{l}\text { - envirronmental hygiene } \\
\text { (air, soil, water) }\end{array}$ & \\
\hline - hearing loss & - noise reduction & $\begin{array}{l}\text { - periodic examination } \\
\text { (audiometry) }\end{array}$ \\
\hline $\begin{array}{l}\text { - occupational diseases } \\
\text { other than cencer/ } \\
\text { injuries/hearing loss }\end{array}$ & - industrial hygiene & - periodic examination \\
\hline - eye problems/vision & $\begin{array}{l}\text { - periodic examination } \\
\text { (pre-school, school) } \\
\text { - periodic examination } \\
\text { (ocular tension, diabetes }\end{array}$ & \\
\hline $\begin{array}{l}\text { - osteoporosis/ } \\
\text { hip fractures }\end{array}$ & $\begin{array}{l}\text { - diet? } \\
\text { - medication? } \\
\text { - exercise } \\
\text { - prevention of falls }\end{array}$ & \\
\hline - diabetes & $\begin{array}{l}\text { - diet? } \\
\text { - weight reduction? }\end{array}$ & - (mass) screening? \\
\hline
\end{tabular}

A correlation between decline in avoidable mortality and health care activities does exist but is not as straightforward as one would wish.

In table 3.4, existing or proposed preventive measures for a number of health problems are presented; some of these programmes do not have the above-mentioned scientific basis and may be neither effective nor efficient. Several important health problems are not mentioned at all, because primary or secondary prevention is not feasible or is recommended for certain high-risk groups only 
(Fisher 1989). This applies for dementia and various forms of arthritis, for example.

The various health problems are not presented in order of magnitude or severity (according to the indicators used in chapter 2 ) or preventability. This is not possible because there is not a comprehensive indicator that measures morbidity and mortality and, as mentioned above, because scientific information on preventability is not abundant. However, the possibility of assigning priorities to at least some prevention programmes will be considered in $\S 3.8$ and elaborated upon in chapter 7 .

As an example, some information on the preventability of a few specific health problems is given in the following paragraphs (\$3.5.1 - 3.5.3). Cancer and cardiovascular disease have been chosen because they are the main causes of death and important causes of morbidity. Congenital and genetic diseases were selected partly because they are quite important health problems but especially because of the rapid developments in this field. Unfortunately it is not possible to discuss the preventability of other health problems mentioned in table 3.4 in this manner within the scope of this report. Neither can we go into the (lack of) possibilities of preventing other important and interesting health problems, such as mental health, dementia, low backpain, home and leisure injuries, diabetes and osteoporosis.

\subsubsection{Preventability of cancer}

Table 3.5 is based on the publication "Cancer risks and prevention" (Vessey and Gray 1985). It shows the maximum effectiveness of existing preventive measures to diminish the cancer problem in the United States of America and the number of cancer deaths that could theoretically be prevented in the Netherlands if the determinants presented here were to be eliminated completely (STG 1988b; Schaapveld and Cleton 1989). The paramount importance of smoking is obvious, and so are the very limited effects of other measures. 
Table 3.5 Effectiveness of various measures to avoid cancer

\begin{tabular}{|c|c|c|}
\hline $\begin{array}{l}\text { Prevention of cancer } \\
\text { by avoidance of }\end{array}$ & $\begin{array}{l}\text { percentage of } \\
\text { cancer mortality } \\
\text { thus avoided }\end{array}$ & $\begin{array}{l}\text { corresponding } \\
\text { number of deaths } \\
\text { due to cancer per } \\
\text { year in the } \\
\text { Netherlands }\end{array}$ \\
\hline tobacco smoke & 30 & 10,000 \\
\hline alcohol & 3 & 1,000 \\
\hline obesity & 2 & 700 \\
\hline $\begin{array}{r}\text { cervical cancer (by screening and } \\
\text { genital hygiene) }\end{array}$ & 1 & 350 \\
\hline $\begin{array}{c}\text { nonessential use of hormones and } \\
\text { radiology }\end{array}$ & $<1$ & 350 \\
\hline $\begin{array}{l}\text { excessive exposure to sunlight } \\
\text { exposure to known carcinogens in: } \\
\text { the occupational context } \\
\text { food, drinking water, air }\end{array}$ & $\begin{array}{l}<1 \\
<1 \\
<1\end{array}$ & $\begin{array}{l}350 \\
350 \\
350\end{array}$ \\
\hline approximate total & $38-40$ & 13,000 \\
\hline
\end{tabular}

Source: Vessey and Gray 1985; STG 1988b

The case against smoking is overwhelming, both for cancer and cardiovascular disease (Peto 1985; Fielding 1985; Wynder 1988). Apart from lung cancer, smoking also contributes to the incidence of other, rarer types of cancer such as cancer of the mouth, oesophagus, larynx, pancreas, urinary bladder, kidney and cervix (STG 1988b). The risk of cancer and other conditions from involuntary (passive) smoking is quite limited, except for a lower birthweight and higher perinatal mortality for children born to smoking mothers. Smoking seems to offer some protection against ulcerative colitis, Parkinson's disease and endometrial cancer (Coebergh 1990).

Alcohol may be a minor risk factor for cancer - mainly of the mouth, larynx, pharynx, oesophagus and probably breast - but given the possibilities for prevention it should be included in cancer control programmes (Anonymous 1990b).

Speculation on the proportion of all cases of cancer attributable to diet is so tenuous as to be almost frivolous (Freudenheim and Graham 1989). On the basis of current knowledge, it is not yet possible to make firm recommendations on nutrition that relate specifically to cancer (Hennekens 1986; Byers 1988; 
Freudenheim and Graham 1989; Ministry of Welfare, Health and Cultural Affairs 1989b), but some do not agree (Crawford 1988, Prentice et al 1988). Considerable research is being carried out in this field and in the future more may be known about the advantages of micronutrients, less fat, fewer calories and more fibre, although some doubt the feasibility of primary cancer prevention trials (Zelen 1988). In the meantime, the general recommendations on nutrition for the prevention of cardiovascular disease could be used since they certainly will not hamper cancer prevention and might even have a positive effect.

The National Cancer Institute of the United States has set objectives for cancer control for the year 2000, based mainly on cancer prevention (Greenwald and Sondik 1986). These objectives have been attacked as being unrealistic by some (Bailar and Smith 1986, Miller 1986), because the course of present trends cannot be changed as quickly as hoped and because the preventability of cancer has been exaggerated. Others defend the cancer objectives because - except for lung cancer - trends appear promising, especially for younger age groups (Breslow and Cumberland 1988).

The European "Health for all by the year 2000" strategy has as one of its 38 health objectives a $15 \%$ reduction in the age-adjusted cancer mortality rate for individuals below the age of 65 . If present trends persist, this objective will not be reached in the Netherlands (Ministry of Welfare, Health and Cultural Affairs 1989b).

In the field of secondary prevention, screening programmes for several types of cancer have been proposed or tried (Eddy 1986). Most research has been directed toward the prevention of cancer of the breast and cervix by means of mass screening programmes; the cost and effectiveness of those programmes will be discussed in $\S 3.7$.

At present screening the general population for colorectal cancer, one of the most common types of cancer in the industrialized world, does not appear to be justified (Rozen et al 1987; Clayman 1989; Anonymous 1990c).

Screening the elderly male population for another common type of cancer, carcinoma of the prostate, might be feasible, but it is doubtful whether this will prolong survival (Pedersen et al 1990). 


\subsubsection{Preventability of cardiovascular disease}

Most authors agree that the age-adjusted incidence rates and specific mortality rates for the two main manifestations of cardiovascular disease - myocardial infarction and stroke - can be decreased by influencing one or more of the wellknown risk indicators mentioned below. There are, however, some dissenting voices in the chorus of supporters of prevention of the main cause of death and a major cause of morbidity in the industrialized world. "Coronary heart disease is not preventable by population interventions" is the title of an article by McCormick and Skrabanek (McCormick and Skrabanek 1988); others concur (Boot 1987; Smith et al 1989; Brett 1989). The results of research and the theoretical concepts underlying the prevention of cardiovascular disease have proliferated to such an extent that it is barely possible to unravel the various vocal parts of the chorus. The scope of this book does not allow a full discussion or even mention of all major trials and theories and therefore only a broad outline can be given. The techniques for and evaluation of prevention trials for cardiovascular disease have been described elsewhere (Rose 1985b; Pocock and Thompson 1990).

The main risk indicators for cardiovascular disease are: elevated serum cholesterol level, hypertension (Hebert et al 1988; Collins et al 1990; MacMahon et al 1990), cigarette smoking, obesity (Manson et al 1987; VanItallie 1990; VanItallie and Stunkard 1990), diabetes, mental stress and (lack of) physical exercise (Anonymous 1987a; Anonymous 1987c; Epstein and Pyörälä 1987; Lewis 1987; Blackburn 1989; Sytkowski et al 1990).

There is a possibility that a low serum cholesterol level is associated with an increased risk of other diseases (Sherwin et al 1987; Anonymous 1989; Isles et al 1989; Blackburn 1989). This is discussed further in chapter 6.

Excessive alcohol is a risk factor but probably not an important one and moderate drinking may even offer some protection (Ferrence et al 1986; Shaper et al 1987; Regan 1990).

Other risk factors, which cannot however be influenced, are a family history of cardiovascular disease and previous symptoms (Pekkanen et al 1990). 
From migrant studies and analysis of geographic variations (Elford et al 1990) it has been concluded that life-style-related factors are more important determinants of cardiovascular disease than genetic differences. A consequence of this finding is that it improves the chances for prevention. However, it has to be kept in mind that the above-mentioned indicators explain only part of the problem (Oliver 1986; Epstein and Pyörălă 1987; Rose 1990); moreover curative care such as cardiac surgery - is another important way to lower cardiovascular mortality (Neutze and White 1987; Sytkowski et al 1990).

Myocardial infarction and stroke are not influenced to the same extent by the same indicators (Bloch and Richard 1985). The protective effects of treatment of hypertension are more obvious for stroke than for myocardial infarction (Chobanian 1988; Hebert et al 1988; Collins et al 1990; MacMahon et al 1990; Menotti et al 1990), whereas the reverse applies for the protective effects of cholesterol control (Hiroyasy et al 1989).

Despite all of the optimism about the preventability of cardiovascular disease it appears that the total mortality rates did not decrease more in the study groups than in the control groups of most intervention trials; the MRFIT study seems to be one of the exceptions (MRFIT Research Group 1990). This phenomenon will be discussed in chapter 6 .

Risk indicators for cardiovascular disease can be influenced by programmes of primary (antismoking policy, nutrition guidelines, exercise, some drugs) and secondary (screening and, if necessary, treatment for high serum cholesterol levels, hypertension and diabetes) prevention. There is controversy about whether these programmes should be directed towards the whole population or high risk groups or both (Rose 1985a; Olson 1986; Lewis et al 1986; Epstein and Pyörălă 1987; Tunstall-Pedoe 1989; Leaf 1989; Kinlay and Heller 1990): to put it more bluntly, should risk factors be treated statistically or selectively. Both strategies have advantages and disadvantages. The main disadvantage of the high-risk strategy is the low predictive value of the presence or absence of risk indicators: it is very difficult to predict who will suffer a heart attack or a stroke and who will not. In addition, the large number of people at small risk will still yield more cases of cardiovascular disease than the small number at high risk. 
The biggest drawback of the population strategy is similar in nature and has been called the "prevention paradox" by Rose (Rose 1985a): a prevention measure which offers considerable benefit to the total population offers little to each participating individual.

There is no such thing as a simple weighted score incorporating the values for the different risk factors to help the physician decide who should receive preventive treatment and who should not, but it is clear that a decision to treat generally should not be based on the presence of one risk factor only.

The European health objective of a $15 \%$ reduction in the age-adjusted cardiovascular mortality rate for persons below the age of 65 can be reached in the Netherlands by the year 2000 only if present trends continue (Ministry of Welfare, Health and Cultural Affairs 1989a).

\subsubsection{Preventability of genetic and congenital diseases}

Genetic and congenital diseases constitute a health problem of considerable magnitude in the Netherlands, as shown in tables 2.4, 2.5 and 3.6 (STG 1988a). The relatively high incidence of $3-6 \%$ of all newborn children listed in this table is especially serious because by definition it concerns morbidity from the beginning of life. These congenital anomalies vary from hardly noticeable to life-threatening and from obvious at birth to latent until later in life, sometimes much later as in Huntington's disease and familial hypercholesterolaemia. It is therefore not always clear what should be included in this group of diseases.

Others give a lower estimate of $2-3 \%$ of the approximately 190,000 babies born in the Netherlands every year; but they include only the more serious cases in their calculations (Ministry of Welfare, Health and Cultural Affairs 1987). Nineteen regions participating in the European EUROCAT registry reported between 12.2 and 32.4 cases of the most common congenital anomalies per 1000 live births, foetal deaths and induced abortions over the period 1980-1986 (EUROCAT 1989). Most of the variation between registries and over time is explained by methodological differences. An American study reported that $7.44 \%$ of liveborn children showed one or more major morphological congenital 
anomalies, causing considerable postnatal mortality and morbidity (Chung and Myrianthopoulos 1987).

Iable 3.6 Estimate of the annual number of live newborn children in the Netherlands with a congenital anomaly

\begin{tabular}{lll}
\hline CAUSE & EXAMPLE & NUMBER \\
\hline $\begin{array}{l}\text { 1. non-hereditary exogenous } \\
\text { influences }\end{array}$ & $\begin{array}{l}\text { radiation, infection, } \\
\text { drugs }\end{array}$ & 1000 \\
$\begin{array}{l}\text { 2. abnormalities in number } \\
\text { or form of chromosomes } \\
\text { (rarely hereditary) }\end{array}$ & Down's syndrome & $800-900$ \\
$\begin{array}{l}\text { 3. hereditary mutations of one } \\
\text { or more genes }\end{array}$ & $\begin{array}{l}\text { familial hyper- } \\
\text { cholesterolaemia, } \\
\text { phenylketonuria }\end{array}$ & $700-2300$ \\
$\begin{array}{l}\text { 4. multifactorial (combination } \\
\text { of hereditary and non- } \\
\text { hereditary causes) }\end{array}$ & $\begin{array}{l}\text { congenital heart } \\
\text { disease, cleft lip, } \\
\text { spina bifida }\end{array}$ & $3500-7000$ \\
\hline TOTAL & & $\begin{array}{l}6000-11200 \\
\text { (i.e. } 3-6 \% \text { of all } \\
\text { newborn children) }\end{array}$ \\
\hline
\end{tabular}

Source: STG 1988a

Some 5000 types of genetic and congenital diseases are known at present (Galjaard 1988). Most of them - approximately 4000 - are caused by mutation of a single gene. The exact molecular defect has been determined for only about 400 of these (Galjaard 1989). However, the category of diseases of multiple or unknown origin encompasses a far greater number of patients. Some genetic diseases occur only in certain ethnic groups (Modell and Modell 1990).

Reported prevalence rates for mental retardation vary markedly in various countries, according to the definition used (Kiely 1987). In the Netherlands, approximately 30,000 mentally deficient people are residents of institutions ( 2.1 beds per 100,000 population). Even more live outside institutions, mainly those with milder forms of retardation. The cause of retardation of most Dutch patients is 
not known. In other countries, chromosomal anomalies (especially Down's syndrome, but also fragile $\mathrm{X}$ syndrome and others) and congenital malformations (such as neural tube defects) seem to account for over $60 \%$ of the more severe cases of mental retardation (Kiely 1987), which may give an impression of the theoretical preventability.

One can try to reduce the incidence of genetic and congenital diseases by primary and secondary prevention (Anonymous 1987b; Silman and Allwright 1988; Bull 1990). Galjaard estimates that in the Netherlands at present the births of 550-1100 handicapped children are avoided annually as a result of preventive activities, i.e. 15-30\% of the more serious cases.

The difficulty for primary prevention is the fact that most cases are of multiple or unknown origin. For secondary prevention it is not essential to know the cause of the anomaly.

The ethical and social issues involved have been described elsewhere (Anonymous 1987b; Galjaard 1988; Clarke 1990). These issues will become even more important in view of the rapidly evolving techniques for testing and intervention.

Primary prevention involves genetic screening of both parents before the conception of a child, if necessary followed by genetic counseling. It is also directed towards the prevention of harmful exogenous influences after conception, such as certain infections or smoking by the mother. Pregnancy of older women and consanguinity between parents are other risk factors that are amenable to primary prevention. Examples of health problems suitable for primary prevention are congenital rubella syndrome, congenital syphilis, thalassaemia, sickle cell disease and muscular dystrophy. A primary prevention programme for cystic fibrosis may be a realistic option soon (Anonymous 1990a; Anonymous 1990d), but others are not as optimistic (Wilfond and Fost 1990; Workshop 1990).

Secondary prevention consists of prenatal screening followed by abortion if a serious abnormality is found. Another example is abortion after a proven rubella infection during the first three months of pregnancy in a non-immune woman. Secondary prevention programmes, such as screening for Down's syndrome and neural tube defects, exist in many countries. Participation in these programmes is 
often much less than 100\%: in the Netherlands only $37 \%$ of the pregnant women aged 36 years and older undergo at present screening for chromosomal anomalies (Cornel et al 1990).

Another form of secondary prevention - bordering on tertiary prevention - of congenital disease is the screening of newborn children for hypothyroidism, phenylketonuria and some rarer metabolic diseases (Nyhan 1985). These can be treated if diagnosed early. However, for other genetic diseases, antenatal screening seems preferable to neonatal screening, and preconceptional screening seems to be the best of all (Modell 1990).

It is difficult to estimate the proportion of genetic and congenital diseases that could be eliminated through prevention programmes. Prevention should be possible for many conditions caused by non-hereditary exogenous influences, most chromosome disorders, a number of single gene mutations and most neural tube defects. This would mean roughly half of the present incidence (i.e. 2000 cases per year in the Netherlands), if widespread screening were to be accepted, or more than double the figure mentioned by Galjaard.

Our knowledge about the human genome is growing rapidly (Watson and CookDegan 1990). Cheaper and easier tests for more abnormalities will become available for screening prospective parents and in early pregnancy (STG 1988a).

At some later stage in the future it may be possible to detect after birth who will run a higher risk for cardiovascular disease, some types of cancer or diabetes. Regular examination of these people may catch the disease at an early, still curable, stage; such postnatal genetic screening may eventually become an accepted form of secondary prevention. But it is also easy to imagine that this knowledge would be intolerable for those at high risk, and that others might use it against them.

The only WHO European health objective that is directly concerned with congenital disease is number five: the incidence of congenital rubella syndrome and congenital syphilis should be zero in Europe by the year 2000. This is feasible but will probably not be achieved for congenital rubella in view of the present immunization coverage rates (Silman and Allwright 1988). Nowadays cytomegalovirus, varicella and toxoplasmosis are more important infectious 
causes of congenital disease than rubella and syphilis, but they are not (yet) or less easily preventable (Best and Banatvala 1990).

\subsection{The costs of health benefits through prevention}

\subsubsection{Prevention and the costs of health care}

It is a common fallacy that prevention reduces the costs of health care. Prevention may prevent or lower the incidence of certain diseases, improve the quality of life or lengthen lifetime. It cannot, however, prevent us from ultimately dying. A longer or better life does not necessarily imply that fewer resources are spent on health care when expenditure over a whole lifetime is taken into account.

When we compare, for example, the lifetime health costs of a smoker with those of a non-smoker, it appears that the smoker consumes more health care per year than the non-smoker but that their total lifetime costs are the same (Leu and Schaub 1983) or nearly the same (Lippiatt 1990). Up to now there has been no conclusive evidence to show that a life made longer as a result of preventive activities also means a correspondingly lower expenditure on health care (see also chapter 5).

Prevention as a rule does not save money on health care. Yet there is no point at looking at the expenditure on prevention without taking the benefits of prevention into account. Some of these benefits cannot be expressed in money terms, e.g. the improvement in the quality of someone's life, and these effects are unfortunately often neglected when it comes to calculating the total costs of a prevention programme. The decision to carry out a preventive programme should be based on a careful consideration of all the costs, all the possible risks and all the possible benefits of the programme. In some cases the programme may be worth carrying out, in others not. Russell (1986) gives the historic example of the smallpox vaccination. In 1920 there were 110,000 cases of smallpox reported in the U.S.A.. Even though the vaccination caused adverse reactions, the benefits far outweighed the risks and costs. By the 1950's smallpox had been eradicated from the U.S.A., Canada and its major trading partners, yet millions of people 
were still being routinely vaccinated. In the 1960's two large surveys (Neff et al 1967; Lane et al 1969; Lane et al 1970a; Lane et al 1970b) were carried out which established the serious effects of complications from the vaccination and recommendations were made for continued quarantine combined with vaccination of high risk groups only. It was calculated that over a thirty-year period this policy would result in 60 deaths as opposed to 210 under a continued policy of routine vaccination. The medical costs involved for administering the 14 million vaccinations in 1968 were estimated to be $\$ 93$ million and a further $\$ 42$ million represented the loss of potential earnings due to disability or death as a result of the vaccination and time taken off work to be vaccinated. In 1971 the U.S.A. finally opted for a selective policy (see also Koplan 1985).

\subsubsection{The economic evaluation of health programmes}

Given that resources are limited, choices have to be made in allocating scarce resources. Economic evaluation uses the criterion of economic efficiency, i.e. the maximisation of benefits for the least cost (see also $\S 7.3$ ). The two methods which are the most commonly used in the economic appraisal of prevention are cost-benefit and cost-effectiveness analysis, while cost-utility has recently been gaining ground in the measurement of the quality of life. Cost-benefit analysis was originally used for the appraisal of government investment: should a new airport, motorway or bridge be built and who will benefit or lose from this investment? In this kind of analysis the social costs and benefits, as opposed to only the private ones in private investment, are taken into account. The building of a new road may, for example, bring the benefit of less travelling time for road users, but also the inconvenience of the extra noise for local people. These are examples of some of the social costs and benefits which are included in costbenefit analysis (for an understanding of the theory of cost-benefit analysis, see the classic works: Dasgupta and Pearce 1972; Layard 1974; Mishan 1982).

In the 1960's cost-benefit analysis started to be applied for the first time to the health sector in order to evaluate investment expenditure on medical interventions and prevention programmes. The main question to be answered was whether the benefits of resources devoted to prevention (and other health programmes) 
outweighed the (opportunity) costs, i.e. the costs of using resources which could have been put to other uses. Cost-benefit analysis is based on the principle that any investment involves a sacrifice and that the investment is only worthwhile if the value of the benefits from this investment are at least as great as the costs.

When two or more programmes are competing for scarce resources, then the programme with the greatest net benefits should be preferred. In this way social welfare can be increased.

In cost-benefit analysis all the costs and benefits are expressed in money terms. This makes cost-benefit a useful tool for determining whether a programme is worth undertaking since both benefits and costs are expressed in the same unit (in this case money). It is for this reason also useful for comparing the costs and benefits of two programmes with two different health outcomes, e.g. one programme aimed at reducing mortality and the other aimed at reducing work disability, for example. Unfortunately many costs and benefits are difficult to evaluate in money terms and their evaluation is a subject of controversy among economists (see Schelling 1973; Dawson 1973; Zeckhauser 1975; Graham and Vaupel 1981; Schelling 1986; Fuchs and Zeckhauser 1987).

Cost-effectiveness analysis is being increasingly used in the evaluation of health programmes. It differs from cost-benefit analysis in that the benefits are not expressed in money terms but in terms of units of health effects, e.g. number of life years saved (see also $§ 3.2$ ). Cost-effectiveness analysis cannot therefore tell us whether the programme is worth being carried out since net benefits cannot be calculated. It is useful, however, for other purposes, e.g. when comparing two programmes where the benefits can be expressed by the same health effect, as with the number of lives saved through screening for breast or cervical cancer, or comparing alternative scenarios within the same programme. A cost-effectiveness ratio, e.g. costs per life saved, means little on its own and a programme cannot be said to be "cost effective". It can only be more or less cost effective than another using the same unit of health outcome (see also Wolfe 1973; Weinstein and Stason 1977; Warner and Luce 1982; Holland 1983; Cohen and Henderson 1988; Drummond et al 1989).

Cost-utility analysis is a relatively new technique in health care evaluation, which overcomes the problem of trying to assess health effects in money terms 
as in cost-benefit analysis and of measuring life years gained irrespective of their quality as in cost-effectiveness analysis. The outcome of the programme is measured by the (improvement in the) quality of life, usually expressed as healthy days or quality adjusted life years (QALYs) (see also $\S 3.2$ ). This "adjusted" outcome is arrived at by weighting the original outcome by the "utility" value on a scale from 0 to 1 . This utility value is obtained from judgement, values from the literature or values from measurement on a sample of subjects. (The methods that may be used to measure the quality of life are explained by Torrance 1986 and Drummond et al 1989). Again, as with cost-effectiveness analysis, cost-util-ity analysis cannot be used to decide whether a programme is worth undertaking, since it cannot tell us whether the benefits outweigh the opportunity costs.

A word of caution. Economic evaluation is a useful framework for identifying the many benefits and costs of a programme and makes difficult choices explicit. But because it gives a quantitative solution to the problem of choice, this may lead some people to accept these results unquestioningly. It must be remembered, however, that any judgement based on the results of the economic analysis must ultimately lie with the final decision maker who may determine his choice on criteria other than purely economically efficient ones (see also Cohen and Henderson 1988 on the distributional issues involved in clarifying social goals; Hiatt and Weinstein 1985 on how to set priorities in prevention).

\subsubsection{The economic evaluation of prevention programmes}

Prevention programmes differ from interventions in the curative sector in several respects (see also $\S 3.1$ ). In the first place, the effects of prevention usually take place a long time after the costs are made whereas in curative care the two usually coincide. Furthermore these future benefits are not always predictable because many other factors can influence the final outcome in the meantime. When the costs and benefits of a prevention programme are being calculated, both the length of time between costs and effects and the degree of uncertainty of the outcome must be taken into account. This is done by "discounting" the stream of expected costs and benefits for the required time profile. The effect of discounting is to reduce the total stream of costs and benefits by 
the "discount factor", expressed as $(1+r)^{-n}$ where $r$ is the discount rate and $n$ is the number of years taken into consideration. For example, $\$ 100$ discounted at $5 \%$ is equivalent to $\$ 78$ after 5 years and $\$ 61$ after 10 years. This is due to the existence of time preference: as individuals we prefer money to-day rather than money to-morrow and we are only prepared to trade in to-day's money on condition that we get some extra return for it in the future. Discounting takes this time preference into account, as well as the uncertainty factor and the opportunity cost of capital. There is a vast body of literature concerning the choice of the discount rate, which we shall not go into here. In practice, the current rate recommended by government is used (at present $5 \%$ in the Netherlands). Very of ten a range of rates are used, varying from 0 to $10 \%$, in order to see how sensitive the results are to different rates. As a general rule, the higher the discount rate and the greater the length of time between the expenditure of costs and the reaping of the benefits, the lower are the total discounted streams of benefits compared to a situation with no discounting. This necessary need for discounting prevention programmes that yield most of their benefits in the future explains why programmes in the curative sector which have not been discounted often appear more worthwhile in comparison (Weinstein and Stason 1977; Scheffler and Paringer 1980; Jönsson 1985; Cohen and Henderson 1988).

\subsection{Results of the economic evaluation of prevention programmes}

It is not within the scope of this book to give an exhaustive review of all the project evaluations carried out on prevention in the last ten years or more. Our aim is to give a few examples of programmes in primary and secondary prevention which appear to yield positive net benefits or which try to tackle an important health problem. The topics selected for primary prevention are vaccination and anti-smoking measures. Screening for breast and cervical cancer, lowering high blood pressure and reducing serum cholesterol levels have been chosen as examples of secondary prevention programmes. 


\subsubsection{Primary prevention}

McKeown (cited in Cohen and Henderson 1988) has argued that " better nutrition, hygiene, sanitation and family planning have had a much greater impact (on public health) than vaccination or any other medical intervention." We might also add education and income. In industrialised countries we now take sanitation and family planning for granted, yet we see that low income groups have a lower life expectancy than high income groups (see also $\S 2.8 .2$ ). Because the link between poverty and health is very difficult to measure directly, in contrast to the link, for example, between health and vaccination against or screening for a particular disease, it is not possible to apply cost-benefit analysis techniques to compare the effects of a distributional income policy with those of a health programme with quantifiable health effects. The same applies to environmental issues. The effect of environmental pollution (air, water, soil) on health is impossible to quantify. Yet, even though no measurable quantitative evidence can be obtained on many environmental and distributional issues, these issues must not be neglected when considering setting priorities in primary prevention.

We shall now review some of the evidence provided by economic appraisal of prevention programmes (see also Russell 1986; Cohen and Henderson 1988 for detailed case studies).

a. Vaccination.

Immunization against infectious diseases, e.g. poliomyelitis, rubella, measles, diphtheria, pertussis, mumps and in the past smallpox, has been a matter of government concern because of the potential risk of large epidemics. In cost-benefit and cost-effectiveness studies of vaccination programmes the total costs of vaccination, of complications as a result of vaccination and of infections that occur despite vaccination are compared to the total costs of the disease without vaccination. The vaccine benefits are the prevented morbidity and mortality of the disease for which a vaccine is being given. In cost-benefit analysis the net benefits are given by the difference between the benefits and costs expressed in money terms. In cost-effectiveness analysis the outcome is expressed as the net 
costs per unit of health effect in dollars per case of disease averted or death averted or life year gained (see Koplan 1985).

It must be remembered that it is not always possible to compare the outcomes of various studies because studies vary in their definition of costs to be included, in their valuation of premature death, in their choice of discount rate. Furthermore, especially in the case of successful vaccination campaigns, the ratios of benefits to costs will change as the disease starts occurring less frequently.

- Poliomyelitis. The evidence for poliomyelitis vaccination is overwhelming (see Scheffler and Paringer 1980 and Koplan 1985 on the studies of Weisbrod 1971). Weisbrod calculated a rate of return for polio research of around $12 \%$. The net savings per case avoided were estimated to be $\$ 1,350$ annually.

- Rubella. As for the rubella vaccination Schoenbaum et al (1976) estimated that the benefit-cost ratio for the monovalent rubella vaccine given to one million girls at the age of 12 with $100 \%$ compliance is $25: 1$ (see Scheffler and Paringer 1980; Russell 1986; Cohen and Henderson 1988). Koplan and White (1984) updated these results and found a benefit-cost ratio of 13:1 (Koplan 1985).

- Measles. The benefits of the vaccination against measles have been studied in the U.S.A. for the 1963-1968 period (Axnick et al 1969). Vaccination required medical expenditure totalling $\$ 31$ million but it reduced expenditures on institutionalization by $\$ 201$ million. Vaccination saved 973 lives, more than 3000 cases of retardation were spared and hospital admissions were reduced by 58,000 (see also Russell 1986). In 1984 Koplan and White made a new cost-benefit study and found that the benefit-cost ratio for measles was 15:1 (Koplan 1985).

- Mumps. Koplan and Preblud (1982) estimated the costs and benefits of a mumps vaccination programme in which the mumps vaccine was given as part of a measles-mumps-rubella combination. Assuming that $90 \%$ of people are infected by the age of 30 and $60 \%$ of these develop the illness, they calculated that out of a cohort of 1 million people 540,000 cases of mumps and 23 deaths would be averted in thirty years because of mumps vaccination. The mumps vaccination programme would reduce the costs associated with mumps by $86 \%$ with a benefit-cost ratio of 7.4:1. 
- Hepatitis B. Mulley et al (1982) compared the cost-effectiveness of three strategies for vaccination against hepatitis B: (1) vaccinate everyone in the general population; (2) screen everyone and vaccinate those without immunity; (3) do not screen or vaccinate. Neither vaccinating the total population nor screening followed by vaccination would save medical costs for a low risk population with a prevalence rate of $5 \%$ and a $0.1 \%$ attack rate. With a prevalence of $10 \%$ and an annual attack rate of $6 \%$ (as was found with surgical hospital residents) vaccination without prior screening was the lowest cost strategy, $\$ 104$ per case. For the group with a prevalence of $60 \%$ and an attack rate of $15 \%$, as was found among homosexuals, the lowest cost strategy was screening followed by vaccination at a cost of $\$ 66$ per case.

In a cost-effectiveness study of prenatal screening and of immunization for the hepatitis B virus (Arevalo and Washington 1988) it was found that routine screening of all pregnant women in the U.S.A. and immunization would lead to net annual savings of more than $\$ 105$ million in terms of cases of acute neonatal hepatitis and chronic liver disease averted at the national prevalence of $0.2 \%$. These savings would reach $\$ 765$ million per 100,000 pregnant women screened at a prevalence rate of $15 \%$ such as is found in the high-risk populations (see also Jönsson 1987).

-Influenza. Riddiough et al (1983) carried out a cost-effectiveness analysis to evaluate influenza vaccination during the period 1971-1978 in the U.S.A.. For the vaccination of people over the age of 65 , there were net savings in medical costs. For the vaccination of people between the age of 45 and 64 , the costs were $\$ 23$ per healthy life year gained, for people between the age of 25 to $44, \$ 64$. For people between 15 and 24 , the costs rose to $\$ 181$; for younger children this ratio was even higher.

On the basis of the mortality and morbidity figures in the above study, Beyer and Masurel (1983) calculated for the Netherlands that vaccination against influenza would yield net benefits when administered to people of 65 and over. The net costs per vaccination were $f 20$ (approx. $\$ 10$ ) if given to all children between the age of 3 and 14. They were $f 10$ (approx. $\$ 5$ ) if given to all people between the age of 45 and 64 .

Sprenger et al (1987) also took the indirect costs of sickness absenteeism into account in their cost-benefit analysis of influenza in the Netherlands. They cal- 
culated that the costs per vaccination were $f 27$ (approx. \$ 13.5) while the benefits per vaccination were $f 34$ (approx. $\$ 17$ ) if the whole population were to be vaccinated and $f 160$ (approx. $\$ 80$ ) if only the groups at risk were to be vaccinated. The groups at risk also included all people above the age of sixty. The results of their cost-effectiveness analysis showed that the costs per QALY, excluding the indirect costs, were $f 20,000$ (approx. $\$ 10,000$ ) for vaccination of the whole population and $f 2,500$ (approx. $\$ 1,250$ ) for the vaccination of the population at risk. When the indirect costs were included, there were no costs per QALY, only net benefits.

In the Netherlands only $30 \%$ of the population at risk is being vaccinated at present (Sprenger et al 1987), so that there is scope for obtaining further net benefits.

b. Health education about smoking/tobacco taxation

Cigarette smoking is a major cause of morbidity and mortality in most countries. It has been linked to a variety of illnesses, including heart disease, cancer and respiratory disease (see $\S 3.5 .1$ ). In the Netherlands, as in other countries, the percentage of smokers has declined in the last two decades. In the Netherlands $36 \%$ of men and $29 \%$ of women still smoked in 1989 (see table 2.6 and fig.2.5); in the U.S.A. the percentage smokers were $33 \%$ for men and $28 \%$ for women in 1985. It is estimated for the U.S.A. that a total of 270,000 premature deaths in 1980 were due to smoking, resulting in 3.9 million life years lost (Rice et al 1986). The direct costs of smoking were estimated by Rice to be $\$ 23.3$ billion in 1984 , the indirect costs of morbidity $\$ 9.3$ billion and those of mortality $\$ 21$ billion (see also Schelling 1986).

Preventive measures against smoking are aimed at reducing tobacco consumption. Lippiatt (1990) developed a model for calculating the impact of changes in cigarette sales on medical costs and life expectancy. She calculated that a $1 \%$ decrease in cigarette sales increases life expectancy in the U.S.A. by 1.45 million years and increases medical costs by $\$ 405$ million for the age range of 25 to 79 years. This amounts to $\$ 280$ in added medical costs for each extra year of life gained. The methods used for reducing tobacco consumption are health education, tobacco taxation, restrictions on the advertising of tobacco products and on smoking in public places. Because all these preventive measures usually take 
place simultaneously, it is very difficult to evaluate the effects of individual measures. The economic aspects of health education have furthermore received inadequate attention up to now (Engleman and Forbes 1986). In the case of health education campaigns aimed at wider audiences the quit and relapse rates are still largely unknown (Cohen and Henderson 1988). In the Netherlands the most successful long term quit rates ( $30 \%$ on average) have been reported in the case of interventions by cardiologists and lung specialists. The interventions rely on a behavioral approach to health education in combination with other methods (Kok and Mudde 1988). In a recent study Cummings et al (1989) examined the cost-effectiveness of general practitioners counseling smokers to quit during routine visits. The assumption was made that $2.7 \%$ of smokers would quit as a result of one brief advice. The costs were $\$ 748$ per life year saved, based on an analysis of 45 to 50 -year-old men. When the assumption of a $1 \%$ quit rate was made, the costs were $\$ 5,051$ per life year saved.

Another method for reducing tobacco consumption is tobacco taxation. Godfrey and Maynard (1988) reviewed the economic influences on the demand for tobacco. It appears that the impact of price on the consumption of tobacco is greater than suggested in studies made in the 1970's in the United Kingdom. It seems that a $10 \%$ increase in taxation would cut tobacco consumption by $5-6 \%$ (see also Townsend 1987 on the effect of taxation on social class patterns of smoking).

As for the restrictions on advertising little is known about the quantifiable effects on the consumption of tobacco. Such restrictions will probably have little effect on the consumption by habitual smokers, but may discourage non-smokers from taking up the habit. The restriction on smoking in public places has the effect of enhancing the social disapproval of smoking and this, combined with health education, may help some smokers to give up the habit more easily. Both restrictions will have more effect on the consumption in the long run than in the short run. 


\subsubsection{Secondary prevention}

a. Screening for cancer of the breast and of the cervix

"Screening has the potential of doing more harm than good" (Mant and Fowler 1990). In their article on the theory and ethics of screening Mant and Fowler give a set of minimum criteria which must be fulfilled in order to justify mass screening (see also $\$ 3.1$ ). According to these criteria screening for cervical and breast cancer will save lives if properly organised while screening for lung cancer will not. Eddy (1985) surveyed the effectiveness of screening for cancer in adults and calculated the cost-effectiveness for cancer of the breast, of the colon and rectum, of the lung, of the cervix and others (see also $\S 3.5 .1$ ). He came to the conclusion that screening for cervical cancer had the greatest impact on specific mortality, reducing mortality by $80-90 \%$. The screening for cancers of the breast and colon might reduce mortality by a third, while screening for cancer of the lung probably does not reduce mortality at all.

- Screening for breast cancer. Breast cancer is the most commonly occurring cancer in women. In 1988 the American Cancer Society predicted that 1 out of every 10 women in the U.S.A. will develop breast cancer during her lifetime (Humphrey and Ballard 1989).

Eddy found that approximately two-thirds of the effectiveness of a breast cancer screening programme can be achieved by screening women between the ages of 50 and 75 with annual clinical physical examination alone and bring about a reduction in breast cancer mortality of $21 \%$. Adding annual mammography brings about a further reduction in breast cancer mortality of around $12 \%$ but also increases net costs considerably. He calculated that the costs of annual screening of average-risk women between the ages of 50 to 75 by means of a physical breast examination were about $\$ 5,000$ per life year gained. Adding annual mammography increases the costs per life year gained to $\$ 25,000$ at 1985 prices. Many of the alternatives to be taken into account in a screening programme, e.g. intervals between screening, age group selected, use of mobile units or hospital clinics, will affect the cost-effectiveness ratios. With breast screening as with all screening programmes the amount of money available for prevention and the results one wants to achieve will determine the screening policy to be chosen. 
In the Netherlands the costs and benefits of screening for breast cancer were estimated by de Koning et al (1990) on the basis of ten two-year screening intervals for all women between the ages of 50 and 70 (1990-2017 period) and a $70 \%$ response rate. It was estimated that a stable $16 \%$ reduction in mortality due to breast cancer would be ultimately achieved by the year 2015 . This represents 260,000 life years, or 252,000 quality adjusted life years, gained in that period. The cost-effectiveness ratios are $f 7,650$ per life year gained $(\$ 3,825)$ and $f 8,100$ per QALY $(\$ 4,050)$. These cost-effectiveness ratios are lower than those given by Eddy, mainly because screening intervals are longer and because of better mammography techniques than those available during the New York trials in 1980 on which Eddy's estimates were based (see also van der Maas et al 1989).

- Screening for cancer of the cervix. The IARC working group on the evaluation of cervical cancer screening programmes (1986) found that there was very little difference in the protection afforded by screening every year compared to every three years, but screening every five years offered appreciably less protection. Screening programmes should be aimed principally at women aged 35-60 and the intervals between screening should be three years or less.

Eddy (1985) calculated that the costs per life year gained are about $\$ 700$ for screening from the age of 20 with a five-year interval and $\$ 1700$ with a twoyear interval. Mandelblatt and Fahs (1988) studied the cost-effectiveness of screening low-income elderly women. The average age of the sample of 812 women was 74 years. The early detection of cervical neoplasia saved $\$ 5,900$ in medical costs and 3.7 years of life per 100 tests. The cost-effectiveness ratio per life saved was $\$ 1,600$, based on one screening exercise.

In the Netherlands Habbema et al (1988) calculated with the use of the MISCAN model the cost-effectiveness ratios of screening women in different age categories and with different screening intervals for the period 1988-2015. The lowest cost-effectiveness ratio was obtained by screening women between the ages of $37-73$ with a 6-year interval: $f 24,300$ per life year gained (approx. $\$ 12,150$ ). Screening women between the ages of 27-72 with a five-year interval gives a ratio of $f 28,000$ per life year gained (approx. $\$ 14,000$ ), while screening with a three-year interval raises the ratio to $f 36,500$ per life year gained (approx. $\$ 18,250$ ). This shorter screening interval improves the chances of cancer detection from $80 \%$ to $90 \%$ (IARC 1986) (see also Koopmanschap et al 1990). 


\section{b. Lowering high blood pressure.}

Hypertension is associated with cardiovascular mortality and morbidity. Clinical trials have provided convincing evidence of the effectiveness of reducing diastolic blood pressure above $100 \mathrm{~mm} \mathrm{Hg}$ on the prevention of stroke and congestive heart failure. Results of the effectiveness in patients with levels of blood pressure below $100 \mathrm{~mm} \mathrm{Hg}$ and in the prevention of myocardial infarction are less consistent (Stason 1989; see also $\$$ 3.5.2).

- Detection of hypertension. Edgar and Schnieden (1989) compared the costs of two five-year screening programmes for detecting mild hypertension in two populations aged between 35 and 64 years. In one programme the detection was by population screening and in the other by opportunistic case finding by general practitioners. It was found that the costs of the population screening programme were $£ 25,000$ per prevented stroke (approx. $\$ 41,000$ ), while the costs of the opportunistic case finding programme were $£ 17,050$ per prevented stroke (approx. $\$ 28,000$ ). Not only were the total costs of the opportunistic case finding programme lower but more strokes were detected.

- Treatment of hypertension. Assuming full adherence to regimens, Stason (1989) calculated the cost-effectiveness ratios of treating diastolic blood pressures of 90-94, 95-104 and $105 \mathrm{~mm} \mathrm{Hg}$ or higher. These were respectively $\$ 45,000, \$$ 22,000 and $\$ 9,000$ per QALY (1984 prices). Hence treatment of mild hypertension is much less cost-effective than treatment of higher levels of blood pressure. Stason further adds that treatment of mild hypertension may have deleterious effects on the quality of life because of the negative side-effects of various drug therapies (see also Weinstein and Stason 1985). The costs of different antihypertensive agents also varies widely, ranging from about $\$ 15$ to $\$ 560$ per year of treatment.

The cost-effectiveness of various monotherapies for mild to moderate hypertension was investigated by Edelson et al (1990) for 20 years of therapy with the use of a simulation model. The costs per year of life gained varied from $\$ 10,900$ to $\$ 72,000$, depending on the therapy. The conclusion was that propranolol ( $\$$ 10,900 per year of life gained) was not only the most cost-effective monotherapy but probably also the most effective. Hydrochlorothiazide $(\$ 16,400$ per year of life gained) was comparable in cost-effectiveness but saved only $65 \%$ as many 
years of life (see also Cohen and Henderson 1988; Grimm 1989,1990; Russell 1989).

c. Cholesterol reduction.

The association between serum cholesterol levels and coronary heart disease morbidity and mortality has been clearly established by the Framingham Heart Study (Weinstein and Stason 1985; see also $\S$ 3.5.2). Dietary interventions and drug treatment are used to reduce serum cholesterol levels and the risk of coronary heart disease.

- Dietary interventions. Weinstein and Stason (1985) reviewed dietary interventions and concluded that, while evidence suggests that diet may be effective in reducing cholesterol levels, the effectiveness of dietary interventions has not yet been established (see also Cohen and Henderson 1988; Murray et al 1990).

- Cholesterol-lowering drugs. A recent trial (the Lipid Research Clinics Coronary Primary Prevention Trial) established that the reduction of serum cholesterol through drug treatment does reduce the risk of coronary heart disease. Using the data from the trial and assuming full compliance, Weinstein and Stason (1985) calculated that the costs per life year saved were $\$ 124,000$ (1984 prices) for men in the 45-50 age group whose cholesterol level was greater than $265 \mathrm{mg} / \mathrm{dl}$. In the Netherlands Martens et al (1989) compared the cost-effectiveness of two cholesterol-lowering therapies, simvastatin and cholestyramine. Cholestyramine has been the leading lipid-lowering medication in the Netherlands for many years while simvastatin has only been registered recently. Clinical studies suggest that simvastatin may be more effective in lowering serum cholesterol levels and may be associated with fewer side effects than the older medications. For men with initial cholesterol levels of $310 \mathrm{mg} / \mathrm{dl}$, the cost-effectiveness of cholestyramine varied from $f 220,000$ to $f 510,000$ (\$110,000 to $\$ 255,000$ ) per year of life saved, depending on the age at the start of the therapy. The cost-effectiveness ratio of simvastatin varied from $\int 50,000$ to $f 110,000(\$ 25,000$ to $\$ 55,000)$ per year of life saved. Martens et al recommend that simvastatin should be accepted as the drug of first choice for the treatment of hypercholesterolaemia as its long-term safety record becomes established. 
To be efficient, a preventive action has to produce a sizable health profit for the population at a reasonable cost.

A $10 \%$ reduction in a major health problem could be of more benefit than a $50 \%$ reduction in an unimportant one. Therefore, both the magnitude of the targeted health problem and the degree of preventability enter into the equation for the efficiency of prevention programmes, apart from the costs involved. Preventability could well be lower in practice than in theory, because of difficulties with organization or acceptance.

There is a discrepancy between the magnitude of health problems, as identified in chapter 2, and the degree of (theoretical) preventability of health problems, as discussed in this chapter. Phenylketonuria may be a negligible public health problem, but it is $100 \%$ preventable at relatively low cost. In contrast, mental health problems - including dementia - may be one of the most important causes of suffering, but very few preventive methods are available. Similarly the primary and secondary prevention of most musculoskeletal problems remains elusive.

Of the most common cancers, carcinoma of the colon and rectum is barely or not preventable, lung cancer is very preventable and breast cancer only to a small extent and at a price.

Some of the mortality and morbidity due to accidents could probably be prevented with a variety of measures at a variety of costs.

Cardiovascular disease, a major health problem in the population, is also amenable to quite a number of preventive measures. However, even the fulfilment of these two conditions for prevention may not lead to the results expected: it will be explained in chapters 5 and 6 that yet other factors (called "decompression of morbidity" and "competition of causes of death") may influence the efficiency of prevention programmes, especially programmes against cardiovascular disease. And the efficiency of all prevention programmes can be affected by future demographic, epidemiological and technological developments, as described in chapter 4 .

More or less efficient prevention programmes exist for some smaller or mediumsized health problems. Some of these health problems were major in the past and 
have become small just because of these prevention programmes, for example various infectious diseases as well as complications of pregnancy and childbirth. Other health problems, although not in this league, were and are being prevented to a large extent at low or acceptable costs, for example cervical cancer, some genetic and congenital diseases, dental caries, unwanted pregnancies and childhood development problems.

It is not possible to establish a rank order for prevention programmes based on efficiency by drawing on the bewildering information presented in this chapter and applying a simple "priority formula", but in chapter 7 an attempt will be made to reach a synthesis. 


\section{LITERATURE}

ANONYMOUS. British Cardiac Society working group on coronary heart disease prevention. Lancet 1987a; i:377.

ANONYMOUS. King's Fund forum consensus statement: screening for fetel and genetic abnormality. Br Med J 1987b;295:1551-3.

ANONYMOUS. Prevention of coronary heart disease [Editorial]. Lancet 1987c;i:601-2.

ANONYMOUS. Low cholesterol and increased risk [Editorial]. Lancet 1989; i:1423-5.

ANONYMOUS. Cystic fibrosis: prospects for screening and therepy [Editorial]. Lancet 1990 a; $335: 79-80$.

ANONYMOUS. Alcohol and cancer [Editorial]. Lancet 1990b;335:634-5.

ANONYMOUS. Reducing deaths from bowel cancer [Editorial]. Lancet 1990c;335:1583.

ANONYMOUS. Cystic fibrosis: closing the gap [Editorial]. Lancet 1990d;336:539-40.

AREVALO JA, WASHINGTON E. Cost-effectiveness of prenatal screening and immunization for hepatitis B virus. JAMA 1988; 259:365-9.

AXNICK NH, SHAVELL SM, HITTE JJ. Benefits due to immunization against measles. Public Heal th Reports 1969;84:673-80.

BAILAR JC, SMITH EM. Progress against cancer? N Engl J Med 1986;314:1226-32.

BAILEY NTJ. The mathematical theory of infectious diseases and its applications. London: Charles Griffin \& Company Ltd, 1975.

BANNENBERG AFI, van GINNEKEN JKS. De berekening van gezondheidswinst ten gevolge van gezondheidsbeleid; potentiële gezondheidswinst van enkele interventies op het gebied van preventieve gezondheidszorg en leefwijzen (2 volumes, in Dutch). Non-published documents. Leiden (the Netherlands): NIPG-TNO, 1989.

Best JM, BanatVala JE. Congenital virus infections. Br Med J 1990;300:1151-2.

BEYER WEP, MASUREL $N$. Influenza vaccinatie: de baten worden nog steeds onderschat (in Dutch). Ned $T$ ijdschr Geneeskd 1983; 127:1779-81

BIJKERK H. National vaccination programme in the Netherlands. T Soc Geneesk 1982;60:6702.

BLACKBURN H. Population strategies of cardiovascular disease prevention: scientific base, rationale and public health implications. Annals of Medicine 1989;21:157-62.

BLOCH C, RICHARD JL. Risk factors for atherosclerotic diseases in the Paris prospective study. I. Comparison with other studies. Rev Epidém et Santé Publ 1985;33:108-20.

BOOT CPM. Is behandeling van hoge bloeddruk zinvol? (in Dutch). Medisch Contact 1987;41:1311-4.

BRESLOW L, CUMBERLAND WG. Progress and objectives in cancer control. JAMA 1988; 259:1690 4.

BRETT AS. Treating hypercholesterolemia; how should practicing physicians interpret the published data for patients? N Engl J Med 1989;321:676-80.

BULL MJV. Maternal and fetal screening for antenatal care. Br Med J 1990;300:1118-20. 
BYERS T. Diet and cancer; any progress in the interim? Cancer 1988;62:1713-24.

CARR-hILL RA, HARDMAN GF, RUSSELL IT. Verietions in evoidable mortality and variations in he日lth core resources. Lencet 1987; i:789-92.

CHARLTON JRH, VELEZ R. Some international comparisons of mortality amenable to medical intervention. Br Med J 1986;292:295-301.

ChOBANiAN A. Overview: hypertension and atherosclerosis. Am Heart J 1988; 116:319-22.

CHUNG CS, MYRIANTHOPOULOS NC. Congenital enomalies: mortality and morbidity, burden and classification. Am J Medical Genetics 1987;27:505-23.

CLARKE A. Genetics, ethics, and audit. Lancet 1990;335:1145-7.

CLAYMAN CB. Mass screening for colorectal cancer: ere we ready? JAMA 1989;261:609.

COEBERGH JUA. Tabaksgebruik: genot, hinder, ziekte en beleid (in Dutch). T Soc Gezondheidsz 1990;68:137-46.

COHEN DR, HENDERSON JB. Health, prevention and economics. Oxford/New York/Tokyo: Oxford University Press, 1988.

COLlins R, PETO R, Macmahon $S$ et al. Blood pressure, stroke and coronary heart disease; part 2, short-term reductions in blood pressure: overview of randomised drug trials in their epidemiological context. Lancet 1990;335:827-38.

CORNEL MC, TUERLINGS JHAM, BREED ASPM, TEN KATE LP. Down syndrome in the North-East Netherlands; expectations and reality 1981-1986 (in Dutch, with summary in English). Ned $\mathrm{Ti}$ jjdschr Geneeskd 1990; 134:1852-5.

CRAWFORD P. The nutrition connection: why doesn't the public know? Am J Public Health 1988; 78: 1147-8.

CUMMINGS SR, RUBIN SM, OSTER $G$. The cost-effectiveness of counseling smokers to quit. JAMA $1989 ; 261: 75-9$

DASGUPta AK, PEARCE DW. Cost-benefit analysis: theory and practice. London: Mecmillan, 1972 .

DAWSON RFF. A practitioner's estimate of the value of life. In: Cooper and Culyer (eds). Health Economics. Hammondsworth (UK): Penguin Books, 1973:336-57

DRUMMOND MF, STOODART GL, TORRANCE GH. Methods for the economic evaluation of health care programmes. 2nd ed. Oxford/New York/Toronto: Oxford University Press, 1989.

EDDY DM. Screening for cancer in adults. In: The value of preventive medicine. Ciba Foundation Symposion 110. London: Pitman, 1985:88-110.

EDDY DM. Secondary prevention of cancer: an overview. Bulletin of the WHO 1986;64:421-9.

EDELSON JT, MEINSTEIN MC, TOSTESON ANA, WILLIAMS L, LEE TH,GOLDMAN L. Long-term costeffectiveness of various initial monotherapies for mild to moderate hypertension. JAMA $1990 ; 263: 407-13$.

EDGAR MA, SCHNIEDEN H. The economics of mild hypertension programmes. Soc Sci Med $1989 ; 28: 211-22$.

ELFORD J, PHILLIPS A, THOMSON AG, SHAPER AG. Migration and geographic variations in blood pressure in Britain. Br Med J 1990;300:291-5.

ENGLEMAN SR, FORBES JF. Economic aspects of health education. Soc Sci Med 1986;22:443-58. 
EPSTEIN FH, PYÖRXLA K. Perspectives for the primary prevention of coronary heart disease. Cardiology 1987;74:316-31.

EUROCAT Working Group. Surveillance of congenital enomalies, years 1980-1986. Brussels: Dept. of Epidemiology, Catholic University of Louvain, 1989. (EUROCAT Report no.3)

FERRENCE RG, TRUSCOTT S, WHITEHEAD PC. Drinking and the prevention of coronary heart disease: findings, issues and public health policy. J of studies on Alcohol 1986;47:394408.

FIELDING JE. Smoking: health effects and control. N Engl J Med 1985;313:491-8 and 555-61.

FISHER M (ed). Guide to clinical preventive services. An assessment of the effectiveness of 169 interventions. Report of the U.S. Preventive Services Task Force. Baltimore: William and Wilkins, 1989.

FREUDENHEIM JL, GRAHAM S. TOward a dietary prevention of cancer- Epidemiologic Reviews $1989 ; 11: 229-35$

FUCHS VR, ZECKHAUSER R. Valuing health - a "priceless" commodity. American Economic Review $1987 ; 77: 263-8$.

GALJAARD H. In: de Beaufort ID, Dupuis HM (eds). Handboek gezondheidsethiek (in Dutch). Assen (the Netherlands): Van Gorcum, 1988:395-409.

GALJAARD H. In: Grobbee DE, Hofman A (eds). Epidemiologie van ziekten in Nederland (in Dutch). Utrecht (the Netherlands): Wetenschappelijke Uitgeverij Bunge, 1989:303-9.

van GINNEKEN JKS, BANNENBERG AFI, DISSEVELT AG. Gezondheidsverlies ten gevolge van een aantal belangrijke ziektecategorieën in 1981-1985. Leiden (the Netherlands): NIPG-CBS, 1989.

GODFREY C, MAYNARD A. Economic aspects of tobacco use and taxation policy. Br Med J $1988 ; 297: 339-43$.

GRAHAM JD, VAUPEL JH. Value of a life: what difference does it make? Risk Analysis $1981 ; 1: 89-94$.

GREENHALD P, SONDIK E (eds). Cancer control objectives for the nation: 1985-2000. Bethesda, Maryland: National Cancer Institute, 1986 (Monograph no.2).

GRIMM RH. Epidemiological and cost implications of antihypertensive treatment for the prevention of cardiovascular disease. Journal of Human Hypertension 1989;3:55-61.

GRIMM RH. Treating hypertension and cardiovascular risk: are there trade-offs? American Heart Journal 1990;119:729-32.

GUNNING-SCHEPERS LJ, HAGEN JH. Avoidable burden of illness: how much can prevention contribute to health? Soc Sci Med 1987;24:945-51.

GUNNING-SCHEPERS LJ. The health benefit of prevention. Health Policy 1989;12:1-255.

HABBEMA JDF, van OORTMARSSEN GJ, LUBBE JTN, van der MAAS PJ. The MISCAN simulation program for the evaluation of screening for disease. Computer Methods and Programs in Biomedicine 1984;20:79-93.

HABBEMA JDF, LUBBE JTN, van OORTMARSSEN GJ, van der MAAS PJ. A simulation approach to cost-effectiveness and cost-benefit calculations of screening for the early detection of disease. Eur J Operational Research 1987;29:159-66. 
HABBema JDF, LUBBe JTM, ven AGT hME, ven BALLEGOOIEN M, KOOPMANSChAP MA, van DORTMARSSEN GJ. Kosten en effecten van bevolkingsonderzoek op baermoederhalskanker (in Dutch). Rotterdam (the Netherlands): Instituut Maatschoppelijke Gezoncheidszorg, Erasmus Universiteit, 1988.

HEBERT PR, FIEBACH NH, EBERLEIN KA, TAYLOR JO, HENNEKENS CH. The community-based randomized trials of pharmacologic treatment of mild-to-moderate hypertension. Am J Epidemiol 1988; 127:581-90.

HENNEKENS CH. Micronutrients and cancer prevention. N Engl J Med 1986;315:1288-9.

hIATT hH, WEINSTEIN MC. Hill disease prevention spere the medical commons? In: Ciba Foundation Symposion 110. London: Pitman, 1985 :218-36

HIROYASY I, JACOBS DR, MENTWORTH D, NEATON JD, COHEN JD. Serum cholesterol levels and six-year mortality from stroke in 350,977 men screened for the Multiple Risk Factor Intervention Trial. N Engl J Med 1989;320:904-10.

HOLLAND W. Evaluation of health care. Oxford/New York/Toronto: Oxford University Press, 1983.

HOLLAND W. The "avoidable death" guide to Europe. Heal th Policy 1986;6:115-7.

HUMPHREY LL, BALLARD DJ. Early detection of breast cancer in women. Primary Care $1989 ; 16: 115-32$.

IARC Working Group on Evaluation of Cervical Cancer Screening Programmes. Screening for squamous cervical cancer: duration of low risk after negative results of cervical cytology and its implications for screening policies. Br Med J 1986;293:659-64.

ISLES CG, HOLE DJ, GILLIS CR, HAhTHORNE VM, LEVER AF. Plasma cholesterol, coronary heart disease, and cancer in the Renfrew and Paisley survey. Br Med J 1989;298:920-4.

JAGER JC, POSTMA MJ, van den BOOM FM et al. Epidemiological models and socioeconomic information: methodological aspects of AIDS/HIV scenerio analysis. In: Schwefel D, Leidl R, Rovira J, Drumiond MF (eds). Economic aspects of AIDS and HIV infection. Berlin: Springer Verlag, 1989: 262-81.

JöNSSON B. The value of prevention: economic aspects. In: Ciba Foundation Symposion 110. London: Pitman, 1985: 22-37.

JöNSSON B. Cost-benefit analysis of hepatitis B vaccination. Postgrad Med J 1987;63 suppl 2:27-32.

JUNGE B, THOM TJ. International comparison of mortality: an approach to realistic health objectives. Health Promotion 1987;2:127-38.

KAPLAN RM, ANDERSON JP. A general health policy model: update and applications. Health Services Research 1988;23:203-35.

KIELY M. The prevalence of mental retardation. Epidemiologic Reviews 1987;9:194-218.

KINLAY S, HELLER RF. Effectiveness and hazards of case finding for a high cholesterol concentration. Br Med J 1990;300:1545-7.

KOK GJ, MUDDE AN. De effectiviteit ven de voorlichting over stoppen met roken (in Dutch). In: JONKERS $R$, de HAES HFM, KOK GJ, LIEDERKERKEN PC, SAAN JAM. Effectiviteit van gezondheidsvoorlichting en -opvoeding (in Dutch). Rijswijk (the Netherlands): Uitgeverij voor Gezondheidsbevordering, 1988. 
de KONING HJ, ven INEVELD BM, ven CORTMARSSEN et al. De kosten en effecten van bevolkingsonderzoek naar borstkanker (in Dutch). Rotterdem (the Netherlands): Instituut van Martschappelijk Gezondheidszorg, Erasmus Universiteit, 1990.

KOOPMANSCHAP MA, van OORTMARSSEN GJ, van AGT HMA, van BALLEGOOIJEN M, HABBEMA JDF, LUBBE KTN. Cervical-cancer screening: attendence and cost-effectiveness. Int $J$ Cancer $1990 ; 45: 410-5$.

KOPLAN JP, PREBLUD SR. A benefit-cost analysis of mums vaccine. Am J Dis child $1982 ; 136: 362-4$.

KOPLAN JP, WHITE CC. An update on the benefits and costs of measles and rubella immunization. In: Gruenberg EM et al (eds). Proceedings of the conference on the conquest of two agents that endanger the brain: measles and rubella. Baltimore, London and New York: Oxford University Press, 1984.

KOPLAN JP. Benefits, risks and costs of immunization programmes. In: The value of preventive medicine. Cibe Foundation Symposium 110. London: Pitman. 1985:55-68.

LANE JM, RUBEN EL, NEFF JM, MILLAR JD. Complications of smallpox vaccination 1968. National surveillance in the United States. N Engl J Med 1969;282:1201-8.

LANE JM, RUBEN FL, NEFF JM, MILLAR JD. Complications of smallpox vaccination 1968. Il. Results of ten statewide surveys. J Infect Dis 1970a;122:303-9.

LANE JM, RUBEN FL, ABRUTYN E, MILLAR JD. Deaths attributable to smallpox vaccination, 1959 to 1966 and 1968. JAMA 1970b;212:441-4.

LA PUMA J, LAHLOR EF. Quality-adjusted life-years; ethical implications for physicians and policymakers. JAMA 1990;263:2917-21.

LAYARD $R$ (ed). Cost-benefit analysis. Hammondsworth (UK): Penguin modern economic readings, 1974.

LEAF A. Manegement of hypercholesterolemia; are preventive interventions advisable? N Engl J Med 1989;321:680-4.

LEU RE, SCHAU日 T. Does smoking increase medical expenditure? Soc Sci Med 1983; 17:1907-14.

LEHIS B, MANN JI, MANCINI M. Reducing the risks of coronary heart disease in individuals and in the population. Lancet 1986; i:956-9.

LEWIS B. A strategy for the prevention of coronary heart disease. Lancet 1987;ii:264-5.

LIPPIATT BC. Measuring medical cost and life expectancy impacts of changes in cigarette sales. Preventive Medicine 1990;19:515-32

van der MAAS PJ, de KONING HJ, van INEVELD BM et al. The cost-effectiveness of breast cancer screening. Int $J$ Cancer 1989;43:1055-60.

MACKENBACH JP. Mortality and medical care [Dissertation]. Rotterdam: Erasmus University, 1988.

MACKENBACH JP, BOUVIER-COLLE MH, JOUGLA E. "Avoidable" mortality and health services: a review of aggregate data studies. J Epidemiol Commity Health 1990;44:106-11.

MacMAHON S, PETO R, CUTLER J et al. Blood pressure, stroke and coronary heart disease; part 1, prolonged differences in blood pressure: prospective observational studies corrected for the regression dilution bias. Lancet 1990;335:765-74.

MANDELBLATT JS, FAHS MC. The cost-effectiveness of cervical cancer screening for lowincome elderly women. JAMA 1988;259:2409-13. 
MANSON JE, STAMPFER MJ, HENNEKENS CH, WILLETT MC. Body weight and longevity, a reassessment. JAMA 1987; 257:353-8.

MANT D, FOWLER G. Mass screening: theory and ethics. Br Med J 1990;300:916-8.

MARTENS LL, RUTTEN FFH, ERKELENS DH, ASCOOP CAPL. Cost-effectiveness of cholesterollowering therapy in the Netherlands. Am J of Medicine 1989;87(suppl.4A):54S-58S.

MCCORMICK J, SKRABANEK P. Coronary heart disease is not preventable by population interventions. Lancet 1988; i i:839-41.

MENOTTI A, KEYS A, BLACKBURN h et ol. Twenty-year stroke mortality and prediction in twelve cohorts of the seven countries study. Int J Epidemiol 1990;19:309-15.

MILLER AB. Future plans for cancer control. JAMA 1988;259:1706-7.

MINISTRY OF WELFARE, HEALTH AND CULTURAL AFFAIRS. Nota preventie aangeboren afwijkingen (in Dutch). The Hague: Parliamentary document no.20345, 1987.

MINISTRY OF WELFARE, HEALTH AND CULTURAL AFFAIRS. Ontwerp Kerndocument Gezondheidsbeléid (in Dutch). Rijswijk (the Netherlands): Ministerie van WVC, 1989a.

MINISTRY OF hELFARE, hEALTH AND CULTURAL AFFAIRS. Policy document on cancer control. Rijswijk (the Netherlands): Ministerie ven wVC, 1989b.

MISHAN EJ. Cost-benefit anglysis. 3rd ed. London: George Allen \& Unwin, 1982.

MODELL B. Biochemical neonatal screening. Br Med J 1990;300:1667-8.

MODELL M, MODELL B. Genetic screening for ethnic minorities. Br Med J 1990;300:1702-4.

MOLINEAUX L, GRAMICCIA G. The Gerki project; research on the epidemiology and control of malaria in the Sudan savenna of West Africa. Geneva: WHO, 1980.

MOONEY GH, RUSSELL EM, WEIR RD. Choices for health care. London: Macmillan, 1980.

MORGENSTERN H, BURSIC ES. A method for using epidemiologic data to estimate the potential impact of an intervention on the health status of a target population. J Community Health 1982; 7:292-309.

MRFIT RESEARCH GROUP. Mortality rates after 10.5 years for participants in the Multiple Risk Factor Intervention Trial. JAMA 1990;263:1795-1601.

MULLEY AG, SILVERSTEIN MD, DIENSDAG JL. Indications for the use of hepatitis $B$ vaccine, based on cost-effectiveness analysis. N Engl J Med 1982;307:644-52.

MURRAY DM, KURTH C, MULLIS R, JEFFERY RW. Cholesterol reduction through low-intensity interventions: results from the Minnesota Heart Health Program. Preventive Medicine 1990; 19: 181-9.

NEFF JM, LANE JM, PERT JH, MOORE R, MILLAR JD, HENDERSON DA. Complications of smallpox vaccination I. National survey of the United States 1963. N Engl J Med 1967;276:125-32.

NEUTZE JM, WHITE HD. What contribution has cardiac surgery made to the decline in mortality from coronery heart disease? Br Med J 1987;2\%4:405-9.

NYHAN UL. Neonatal screening for inherited disease. N Engl J Med 1985;313:43-4.

OLIVER MF. Prevention of coronary heart disease - propaganda, promises, problems and prospects. Circulation 1986;73:1-9. 
OLSON RE. Mass intervention vs screening and selective intervention for the prevention of coronery heart disease. JAMA 1986; 255:2204-7.

PEDERSEN KV, CARLSSON P, VARENHORST E, LöFMAN O, BERGLUND $K$. Screening for carcinoma of the prostate by digital rectal examination in a randonly selected population. Br Med J 1990;300: $1041-4$.

PEKKANEN J, LINN S, hEISS G et al. Ten-year mortality from cardiovascular disease in relation to cholesterol level among men with and without preexisting cardiovascular disease. N Engl J Med 1990;322:1700-7.

PETO R. Control of tobacco-related disease. In: The value of preventive medicine. Ciba Foundation symposium 110. London: Pitman, 1985:126-42.

POCOCK SJ, THOMPSON SG. Primery prevention trials in cardiovascular disease. J Epidem Community Health $1990 ; 44: 3-6$.

PRENTICE RL, KAKAR F, HURSTING S, SHEPPARD L, KLEIN R, KUSHI LH. Aspects of the rationale for the women's health trial. J Natl Cancer Inst 1988;80:802-14.

REGAN TJ. Alcohol and the cardiovascular system. JAMA 1990;264:377-81.

RICE DP, HODGSON TA, SINSHEIMER P, BRONNER $W$, KOPSTEIN AN. The economic costs of the health effects of smoking. The Milbank Quarterly 1986;64:489-547.

RIDDIOUGH MA, SISK JE, BELL JC. Influenza vaccination. Cost-effectiveness and public policy. JAMA 1983;249:3189-95.

ROSE G. Sick individuals and sick populations. Int J Epidemiol 1985a;14:32-8.

ROSE G. Role of controlled trials in evaluating preventive medicine procedures. In: The value of preventive medicine. Ciba Foundation Symposium 110. London: Pitman, 1985b:183202.

ROSE G. Preventive cardiology: what lies ahead? Preventive Medicine 1990;19:97-104.

ROZEN $P$, RON E, FIREMAN $Z$ et al. The relative value of fecal occult blood tests and flexible sigmoidoscopy in screening for large bowel neoplasia. Cancer 1987;60:2553-8.

RUSSELL LB. Is prevention better than cure? Washington: The Brookings Institution, 1986.

RUSSELL LB. Cost-effectiveness of antihypertensive treatment: general considerations. Hypertension 1989; 13:141-4.

SCHAAPVELD K, CLETON FJ. Cancer in the Netherlands; from scenarios to health policy. Eur $J$ Cancer $\mathrm{Cl}$ in Oncol 1989;25:767-71.

SCHEFFLER RM, PARINGER L. A review of the economic evidence on prevention. Medical Care $1980 ; 18: 473-84$

SCHELLING TC. The value of preventing death. In: Cooper and Culyer (eds). Health Economics. Hammondsworth (UK): Penguin Books, 1973:295-322.

SCHELLING TC. Economics and cigarettes. Preventive Medicine 1986; 15:549-60.

SCHOENBAUM SC, HYDE JN, BARTOSHESKY L, CRAMPTON K. Benefit-cost analysis of rubella vaccination policy. N Engl J Med 1976;294:306-10.

SHAPER AG, PHILLIPS AN, POCOCK SJ, WALKER M. Alcohol and ischaemic heart disease in middle aged British men. Br Med J 1987;294:733-7. 
SHERHIN RH, WENTWORTH DN, CUTLER JA, HULLEY SB, KULLER LH, STAMLER J. Serum cholesterol levels and cancer mortality in 361,662 men screened for the Multiple Risk Intervention Trial. JAMA 1987;257:943-8.

SILMAN AJ, ALLHRIGHT SPA (eds). Elimination or reduction of diseases? Opportunities for health service action in Europe. Oxford: Oxford Medical Publications, 1988.

SKRABANEK P. Preventive medicine and morality. Lancet 1986;i:143-4.

SMITH A. Qualms about QALYs. Lancet $1987 ; \mathrm{i}: 1134-6$.

SMITH WCS, DAVIS AM, KENICER MB, EVANS AE, YARNELL J. Blood cholesterol: is population screening warranted in the UK? Lancet 1989; ii:372-3.

SPRENGER MJW, BEYER WEP, AMENT AJHA, RUTTEN FFH, MASUREL N. Influenza-vaccinatie leidt tot kostenbesparingen in de gezondheidszorg. T Soc Gezondheidsz 1987;65:222-5.

STASON HB. Cost and quality trade-offs in the treatment of hypertension. Hypertension 1989; 13:145-8.

STG (Dutch steering Committee on Future Health Scenarios). The heart of the future - the future of the heart. Dordrecht (the Netherlands): Kluwer Academic Publishers, 1987.

STG. Anticipating and assessing health care technology. Volume 5, developments in human genetic testing. Dordrecht (the Netherlands): Kluwer Academic Publishers, 1988a.

STG. Cancer in the Netherlands (2 volumes). Dordrecht (the Netherlands): Kluwer Academic Publishers, 1988b.

SYTKOWSKI PA, KANNEL WB, D'AGOSTINO RB. Changes in risk factors and the decline in mortality from cardiovascular disease. N Engl J Med 1990;322:1635-41.

TAYLOR WC, PASS TM, SHEPARD DS, KOMAROFF AL. Cholesterol reduction and life expectancy; a model incorporating multiple risk factors. Annals of Internal Medicine 1987; 106:605-14.

TORRANCE GH. Measurement of health state utilities for economic appraisal. J Health Economics 1986;5:1-30.

TOWNSEND JL. Cigarette tax, economic welfare and social class patterns of smoking. Applied Economics 1987; 19:355-65.

TUNSTALL-PEDOE H. Who is for cholesterol testing? Br Med J 1989;298:1593-4.

VANITALLIE TB. The perils of obesity in middle-aged women. N Engl J Med 1990;322:928-9.

VANITALLIE TB, STUNKARD AJ. Using nature to understand nurture. Am J Public Health $1990 ; 80: 657-8$.

VESSEY MP, GRAY M (eds). Cancer risks and prevention. Oxford: Oxford University Press, 1985.

HARNER KE, LUCE BR. Cost-benefit and cost-effectiveness in health care. Ann Arbor, Michigan: Health Administration Press, 1982.

WATSON JD, COOK-DEGAN RM. The human genome project and international health. JAMA $1990 ; 263: 3322-4$.

WEINSTEIN MC, STASON WB. Foundation of cost-effectiveness analysis for health and medical practices. N Engl J Med 1977; 296:717-21.

WEINSTEIN MC, STASON WB. Cost-effectiveness of interventions to prevent or treat coronary heart disease. Ann Rev Public Health 1985;6:41-63. 
WEINSTEIN MC, COXSON PG, MILLIAMS LW, PASS TM, STASON WB, GOLDMAN L. Forecasting coronary heart disease incidence, mortality and cost: the coronary heart disease policy model. Am $J$ Public Health 1987; $7: 1417-25$.

WEISSBROD BA. Cost and benefits of medical research: a case study of poliomyelitis. J Pol Economy $1971 ; 79: 527-44$.

WHO. The use of quantitative methods in planning national cancer control programmes. Bulletin of the WHO 1986;64:683-93.

WILFOND BS, FOST N. The cystic fibrosis gene: medical and social implications for heterozygote detection. JAMA 1990;263:27T7-83.

WILSON JMG, JUNGNER G. Principles and practice of screening for disease. Geneva: WHO, 1968 (Public Health Paper no.34).

WOLFE JN (ed). Cost-benefit and cost-effectiveness, studies and analysis. London: George Allen \& Unwin, 1973.

WORKSHOP on population screening for the cystic fibrosis gene. Statement from the National Institutes of Health workshop on population screening for the cystic fibrosis gene. N Engl J Med 1990;323:70-1.

WYNDER EL. Tobacco and health: a review of the history and suggestions for public health policy. Public Health Reports 1988; 103:8-18.

ZECKHAUSER R. Procedures for valuing lives. Public Policy 1975;23:420.

ZELEN M. Are primary cancer prevention trials feasible? J Natl Cancer Inst 1988;80;442-4. 


\section{FUTURE DEVELOPMENTS}

\subsection{Introduction}

Many future developments will influence the feasibility, efficiency and desirability of prevention. Political, economical, financial and socio-cultural developments are difficult to predict and will not be discussed in this chapter. Here we shall limit ourselves to a short overview of demographic and epidemiological projections and imminent technological changes. This overview provides only a background for the other chapters and is not directly related to them. When one thinks about prevention in the future, one has to take into account future demographic structures and morbidity patterns as well as the ways in which present and forthcoming preventive technological developments may influence each.

Table 4.1 United Nations population projections

\begin{tabular}{|c|c|c|c|c|c|}
\hline & & \multicolumn{2}{|c|}{$\begin{array}{l}\text { OECD } \\
\text { population }\end{array}$} & \multicolumn{2}{|c|}{$\begin{array}{l}\text { Western Europe* } \\
\text { populat ion }\end{array}$} \\
\hline & & $10^{6}$ & $\begin{array}{l}\% \text { of total } \\
\text { population }\end{array}$ & $10^{6}$ & $\begin{array}{l}\% \text { of total } \\
\text { population }\end{array}$ \\
\hline$\geq 65$ years & $\begin{array}{l}1950 \\
1980 \\
2000 \\
2025\end{array}$ & $\begin{array}{r}46.8 \\
92.6 \\
119.6 \\
172.9\end{array}$ & $\begin{array}{r}8.1 \\
11.5 \\
13.3 \\
17.6\end{array}$ & $\begin{array}{l}12.4 \\
22.1 \\
24.2 \\
31.4\end{array}$ & $\begin{array}{l}10.1 \\
14.4 \\
15.5 \\
20.9\end{array}$ \\
\hline$\geq 75$ years & $\begin{array}{l}1950 \\
1980 \\
2000 \\
2025\end{array}$ & $\begin{array}{l}14.6 \\
35.1 \\
48.6 \\
71.2\end{array}$ & $\begin{array}{l}2.5 \\
4.4 \\
5.4 \\
7.2\end{array}$ & $\begin{array}{r}3.9 \\
9.1 \\
9.9 \\
13.1\end{array}$ & $\begin{array}{l}3.2 \\
5.9 \\
6.3 \\
8.7\end{array}$ \\
\hline
\end{tabular}

France, West Germany, Benelux, Switzerland, Austria

Source: World population prospects, United Nations, New York, 1986 
"One does not really need rigorous demographic analysis to understand that Europe is growing older. A mid-morning bus ride in Copenhagen or Vienna, a few minutes spent in a town square or local shopping centre would probably be sufficient to convince us of the "greying" of industrialized societies" (Lopez 1987). These observations may convince us that there are many elderly people around, especially in the town squares of those two cities at 10 a.m., but this is not the way to become informed about present and future changes in the age structure of industrialized societies. However, demographic projections do show that the greying of these societies is a fact and will continue for several decades.

Increasing life expectancy, declining fertility, cohort effects of the post-World War II birth wave and immigration will influence the size and composition of the populations of developed countries. The overall effect in most of these countries will be a further marked ageing of the population: an increasing proportion of elderly citizens (over 60 or 65 ) but also an increase in absolute number as well as an even faster growth of the segment "the very old" (over 75 or 80) (Lopez 1987; Guralnik et al 1988; Olshansky 1988; van Ginneken and van Poppel 1989; de Jouvenel 1989). This is illustrated in table 4.1 and figure 4.1.

Table 4.1 shows the ageing of the populations of the OECD countries (20 European countries including Turkey and Australia, Canada, Japan, New Zealand and the USA) and a subset of 7 Western European countries where the ageing effect is more pronounced. It is clear that the changes over a period of 75 years are striking: a doubling of the proportion of elderly and almost triple the number of very old.

Figure 4.1 shows the most recent (1988) population forecast for the Netherlands by the CBS. By the year 2000, 13.8\% of the Dutch population will be 65 years and older and $6.2 \%$ will be 75 years and older. When we compare this to the data from table 4.1, we see that the ageing process in the Netherlands lags slightly behind that in most other northwest European countries; however, since the trends are the same, it will finally end up in the same situation as the other countries. Unlike table 4.1 the graph covers a period of "only" twenty years to show that within such a period the trends are visible but not so impressive that 
Figure 4.1 Population forecast for the Netherlands: proportions of 4 age groups

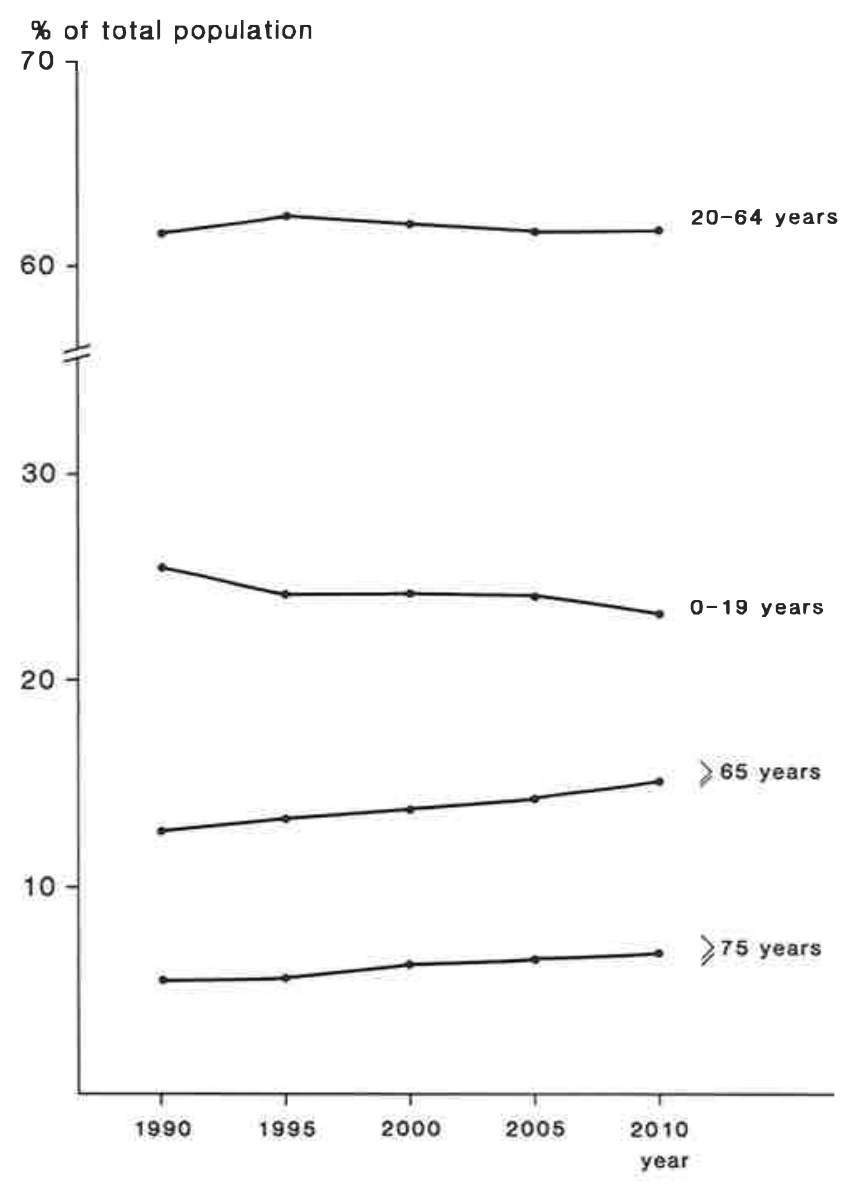

Source: CBS 1989

one would notice a change in the town squares and shopping centres of Amsterdam. However, the importance of the ageing process as far as the health care sector is concerned is that this relatively small segment of the population consumes a disproportionate share of health care funds and services (STG 1987a; van Ginneken and van Poppel 1989; Schneider and Guralnik 1990). In preventive health care, the ageing process may lead to a reduced demand for prevention programmes aimed at younger people and more demand for prevention of chronic morbidity, where feasible. 
In 1983, the Dutch Undersecretary of Public Health established the Steering Committee on Future Health Scenarios (Dutch acronym: STG) to explore future developments in public health and health care. STG scenarios are available for cardiovascular disease (STG 1987b), cancer (STG 1988a), accidents (STG 1989), diabetes (STG 1990a) and psychiatric disorders (STG 1990b). These publications describe possible future trends in morbidity and mortality and the demand for health care as well as some consequences of preventive measures. In a very simplified form, some of these future trends in morbidity have been summarized in table 4.2. Comparability is limited because there are methodological differences in the approaches of the various expert groups responsible for these studies.

Table 4.2 Expected future changes in the incidence and prevalence of some disease categories in the Netherlands, 1990-2010

\begin{tabular}{|c|c|c|}
\hline & $\begin{array}{l}\text { age-adjusted } \\
\text { (rates) }\end{array}$ & $\begin{array}{l}\text { not age-adjusted } \\
\text { (absolute numbers) }\end{array}$ \\
\hline $\begin{array}{l}\text { cardiovascular disease incidence } \\
\text { cardiovascular disease prevalence }\end{array}$ & $-1=$ & $\begin{array}{l}= \\
=/+\end{array}$ \\
\hline $\begin{array}{l}\text { cancer incidence } \\
\text { cancer prevalence }\end{array}$ & $\begin{array}{l}= \\
+\end{array}$ & $\begin{array}{l}+ \\
++\end{array}$ \\
\hline $\begin{array}{l}\text { diabetes incidence } \\
\text { diabetes prevalence }\end{array}$ & + & $\begin{array}{l}+ \\
++ \\
++\end{array}$ \\
\hline $\begin{array}{l}\text { dementia incidence } \\
\text { dementia prevalence }\end{array}$ & $\begin{array}{l}= \\
=1+\end{array}$ & + \\
\hline $\begin{array}{l}\text { schizophrenia incidence } \\
\text { schizophrenia prevalence }\end{array}$ & $\begin{array}{l}= \\
=\end{array}$ & $\begin{array}{l}=/+ \\
=/+\end{array}$ \\
\hline $\begin{array}{l}\text { incidents of accidents } \\
\text { mortality due to accidents } \\
\text { prevalence of handicaps due to accidents }\end{array}$ & $\begin{array}{l}=1+ \\
-1= \\
=1+\end{array}$ & $\begin{array}{l}=/+ \\
-/= \\
=/+\end{array}$ \\
\hline
\end{tabular}

$=$ no change

+ increase

$+\quad$ strong increase

- decrease

Source: STG reports 
As an illustration of one disease category, table 4.3 gives the probable development of cancer prevalence in the Netherlands, as expected by the STG group on cancer. The prevalence for most cancer sites is rising fast because of ageing of the population and longer survival after diagnosis.

All of these scenario studies have focussed on specific disease categories as isolated phenomena. Possible relationships and shifts between disease categories were not taken into account. These will be discussed in chapter 6 .

Iable 4.3 Likely changes in cancer prevalence in the Netherlands between 1985 and 2000: absolute numbers of patients per type of concer

\begin{tabular}{|c|c|c|c|c|}
\hline Tumour site & Sex & 1985 & 2000 & $\begin{array}{l}\text { Percentage } \\
\text { change }\end{array}$ \\
\hline Lung & $\begin{array}{l}M \\
F\end{array}$ & $\begin{array}{l}9,300 \\
1,200\end{array}$ & $\begin{array}{r}13,500 \\
2,600\end{array}$ & $\begin{array}{l}+45 \% \\
+117 \%\end{array}$ \\
\hline Breast & $\mathbf{F}$ & 49,300 & 71,700 & $+45 \%$ \\
\hline Oesophagus & $\begin{array}{l}M \\
F\end{array}$ & $\begin{array}{l}380 \\
350\end{array}$ & $\begin{array}{l}575 \\
555\end{array}$ & $\begin{array}{l}+51 \% \\
+59 \%\end{array}$ \\
\hline Stomach & $\begin{array}{l}M \\
F\end{array}$ & $\begin{array}{l}2,900 \\
2,300\end{array}$ & $\begin{array}{l}3,100 \\
2,500\end{array}$ & $\begin{array}{l}+7 \% \\
+\quad 9 \%\end{array}$ \\
\hline Colon & $\begin{array}{l}M \\
F\end{array}$ & $\begin{array}{r}7,600 \\
11,300\end{array}$ & $\begin{array}{l}12,800 \\
17,200\end{array}$ & $\begin{array}{l}+68 \% \\
+52 \%\end{array}$ \\
\hline Rectum & $\begin{array}{l}M \\
F\end{array}$ & $\begin{array}{l}5,760 \\
5,250\end{array}$ & $\begin{array}{l}7,900 \\
7,400\end{array}$ & $\begin{array}{l}+37 \% \\
+41 \%\end{array}$ \\
\hline Pancreas & $\begin{array}{l}M \\
F\end{array}$ & $\begin{array}{l}420 \\
400\end{array}$ & $\begin{array}{l}520 \\
500\end{array}$ & $\begin{array}{l}+24 \% \\
+25 \%\end{array}$ \\
\hline Cervix uteri* & $F$ & 6,450 & 7,700 & $+19 \%$ \\
\hline Corpus uteri & $\mathrm{F}$ & 9,050 & 13,000 & $+44 \%$ \\
\hline Ovary & $F$ & 5,800 & 9,600 & $+66 \%$ \\
\hline Prostate & M & 11,000 & 18,200 & $+65 \%$ \\
\hline Test is & M & 1,950 & 3,100 & $+59 \%$ \\
\hline
\end{tabular}

Source: STG 1988a; Schaapveld and Cleton 1989 
Other projections have been made by the WHO, including several pertaining to the need for facilities and manpower (WHO 1986), and others who have used the models described in $\S 3.4$.

The rising tide of dementia has been described by Ineichen (1987) and Jorm and Korten (1988). In the Netherlands, the present age-adjusted incidence rate will lead to a $43 \%$ increase in the number of dementia patients, from 105,000 in 1990 to 150,000 in 2010 (STG 1990b).

In general, the incidence and prevalence of chronic conditions and disease will further increase in developed countries as a result of the continuing elimination or postponement of morbidity at younger ages together with the ageing process. This will be discussed further in chapter 5 .

\subsection{Technological changes}

There is still considerable room for expansion of existing prevention programmes (Silman and Allwright 1988), but this cannot really be called a technological change. This is also true for plans to screen the total elderly population for the presence of morbidity as well as several risk factors for future morbidity, because the techniques are already available. Such a programme is a potential minefield that needs careful consideration. Screening should really have something to offer in the way of improving the quality of the remaining years and not merely increase the number of diagnoses and the use of medical services. Results of some screening and intervention trials have been mildly encouraging in this respect (Vetter et al 1984; Hendriksen et al 1984; Hart et al 1990), whereas regular health checkups in a middle-aged population showed no overall benefit (Friedman et al 1986). In a few countries the systematic screening of groups of older people has already started (Weiler et al 1989; Freer 1990).

Many of the new developments in health care technology that the future has in store for us have been described by Banta and his collaborators (Banta et al 1987; STG 1987c; STG 1988b) and others (Spiby 1988). It might be interesting, as far as this report is concerned, to identify new methods in the field of primary and 
secondary prevention that may become available in the last decade of this century. A tentative synopsis is presented in table 4.4. A few of these were already listed (with question marks) in table 3.4.

Table 4.4 Possible developments in primary and secondary prevention by the year 2000

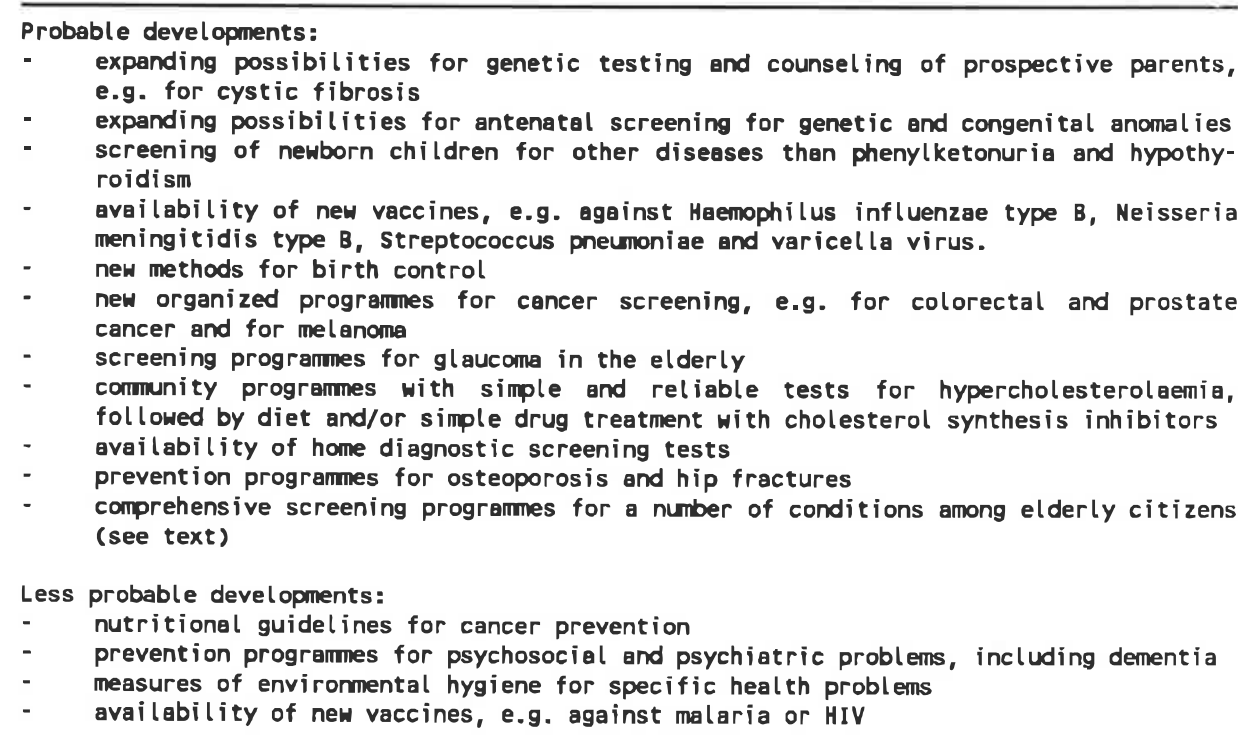

\subsection{Conclusions}

The developed countries will experience a further ageing of their populations. This will cause a shift in the need for preventive and curative health care in the direction of the chronic health problems of older people. There will be no fundamental change in the overall morbidity and mortality patterns, however.

Future technological developments in preventive health care will have an impact on the health services and the health status of the population. Possible developments in primary and secondary prevention have been presented in table 4.4. These forms of prevention may become very effective against hereditary and congenital diseases, but will have only a limited impact on chronic disease and the disability of old age. For this latter category, most developments and requirements will be in the field of tertiary prevention. 


\section{LITERATRE}

BANTA HD, GELIJNS AC, GRIFFIOEN J, GRAAF PJ. An inquiry concerning future health care technology: methods and general results. Health Policy 1987;8:251-64.

CBS (Netherlands Central Bureau of Statistics). Bevolkingsprognose voor Nederland 1988 2050 (in Dutch). The Hegue: SDU Uitgeverij, 1989.

FREER CB. Screening the elderly. Br Med J 1990;300:1447-8

FRIEDMAN GD, COLLEN MF, FIREMAN BH. Multiphasic health checkup evaluation: a 16-year follow-up. J Chron Dis 1986;39:453-63.

van GINNEKEN JKS, Van POPPEL FWA. Some health implicetions of population changes in $f$ ive European countries. T Soc Gezondheidsz 1989;67:47-52.

GURALNIK JM, YANAGISHITA M, SCHNEIDER EL. Projecting the older population of the United States: lessons from the past and prospects for the future. The Milbank Quarterly $1988 ; 66: 283-308$.

HART D, BOWLING A, ELLIS M, SILMAN A. Locomotor disability in very elderly people: value of a programme for screening and provision of aids for daily living. Br Med J 1990;301:216-20.

HENDRIKSEN C, LUND E, STROMGARD E. Consequences of assessment and intervention among elderly people: a three year randomised controlled trial.

Br Med J 1984; 289:1522-4.

INEICHEN B. Measuring the rising tide: how many dementia cases will there be by 2000 ? $\mathrm{Br}$ J Psychiatry 1987; 150:193-200.

JORM AF, KORTEN AE. A method for calculating projected increases in the number of dementia sufferers. Austr NZ J Psychiatry 1988;22:183-9.

de JOUVENEL H. Europe's ageing population, trends and challenges to 2025 . Futures 1989 (Suppl ement): S5-S54.

LOPEZ AD. Demographic aspects of population aging in developed countries. Rev Epidém et Santé Publ 1987;35:195-205.

OLSHANSKY SJ. On forecasting mortality. The Milbank Quarterly 1988; 66:482-530.

SCHAAPVELD K, CLETON FJ. Cancer in the Netherlands, from scenarios to health policy. Eur $J$ Cancer clin Oncol 1989;25:767-71.

SCHNEIDER EL, GURALNIK JM. The aging of America; impact on health care costs. JAMA $1990 ; 263: 2335-40$.

SILMAN AJ, ALLWRIGHT SPA (eds). Elimination or reduction of diseases? Opportunities for health service action in Europe. Oxford: Oxford Medical Publications, 1988.

SPIBY J. Advances in medical technology over the next 20 years. Community Medicine $1988 ; 10: 273-8$

STG (Dutch Steering Committee on Future Health Scenarios). Growing old in the future. Dordrecht (the Netherlands): Kluwer Academic Publishers, 1987a.

STG. The heart of the future - the future of the heart. Dordrecht (the Netherlands) Kluwer Academic Publ ishers, 1987b.

STG. Anticipating and assessing health care technology; vol.1, general considerations and policy conclusions. Dordrecht (the Netherlands): Kluwer Academic Publishers, 1987c. 
STG. Cancer in the Netherlands (2 volumes). Dordrecht (the Netherlands): Kluwer Academic Publ ishers, 1988a.

STG. Anticipating and assessing health care technology; volumes 2-8. Dordrecht (the Netherlands): Kluwer Academic Publishers, 1988b.

STG. Accidents in the year 2000. Dordrecht (the Netherlands): Kluwer Academic Publishers, 1989.

STG. Chronische ziekten in het jaar 2005; scenario's over diabetes mellitus 1990-2005 (in Dutch). Utrecht (the Netherlands): Bohn Scheltema \& Holkema, 19900.

STG. Zorgen voor geestelijke gezoncheid in de toekomst (in Dutch). Utrecht (the Nether(ands): Bohn Scheltema Holkema, 1990b.

VETTER NJ, JONES DA, VICTOR CR. Effect of health visitors working with elderly patients in general practice: a randomised controlled trial. Br Med J 1984;288:369-72.

WEILER PG, CHI I, LUBBEN JE. A statewide preventive health care program for the aged. Public Heal th Reports 1989; 104:215-21.

WHO. Health projections in Europe: methods and applications. Copenhagen: WHO, 1986. 


\section{DOES THE HEALTH OF ELDERLY PEOPLE IMPROVE?}

\subsection{Introduction}

As discussed in $\S 3.2$, an increase in life expectancy is not an appropriate indicator for the effectiveness of a single prevention programme, but the combined preventive strategies may well have contributed to the continuing increase in life expectancy in industrialized countries, both at birth and - to a lesser extent - at advanced age. Therefore, together with prevention, the concept of "compression of morbidity" is receiving more and more attention. Shall we spend the extra number of years allotted to us in good health or are we merely prolonging the terminal phase of sickness and dependency? Nobody can fully predict the future but we can learn from the past. In this chapter the differences in opinion between the optimists and the pessimists will be discussed and some recent Dutch data will be evaluated together with the (scarce) data already available from other countries.

The theoretical concept of compression of morbidity was first formulated by Fries in 1980 (Fries 1980) and again later (Fries 1984; Fries et al 1989). Basically the idea is that we are approaching the upper limits of life expectancy while there are still many ways in which the average age of onset of old-age morbidity can be postponed to a later period in life, thereby shortening the terminal period of morbidity. Old-age morbidity could be delayed by various preventive and curative measures, even for the very old.

Others do not believe in compression of morbidity in the future (Schneider and Brody 1983), first of all because the improvement in life expectancy will not stop at the predicted 85 years (Schneider and Reed 1985) and secondly because recent trends point in the opposite direction: longer life but more morbidity. The theoretical possibilities for compression or decompression (expansion) of morbidity are shown in figure 5.1.

Some of the findings on trends in mortality and morbidity will be summarized here in chronological order. Mortality and life expectancy are determined in a 
Fiqure 5.1 Theoretical possibilities for compression or decompression of morbidity

A present situation:
life expectancy $=75$ years
health expectancy $=60$ years (
period of less than good health $=15$ years (shaded bar)

$B, C$ and $D$ : increase in life expectancy to 80 years

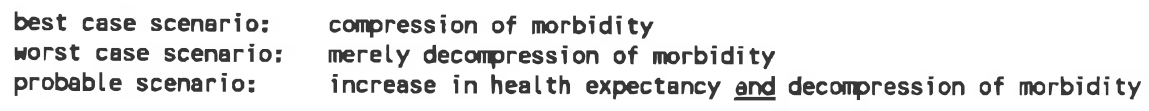

A

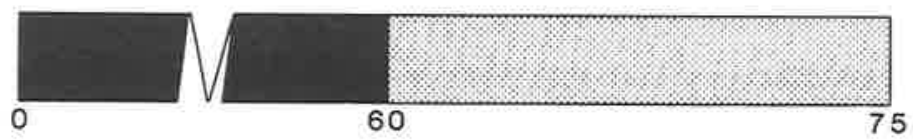

B

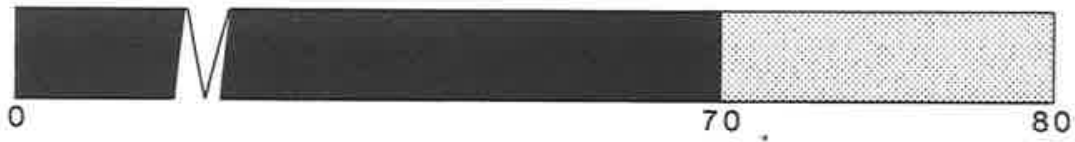

C

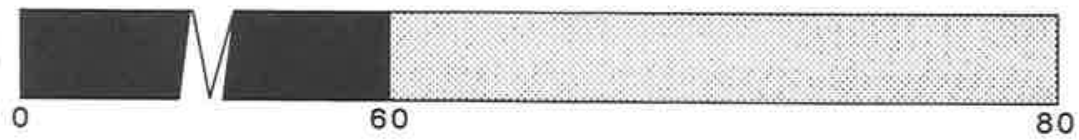

D

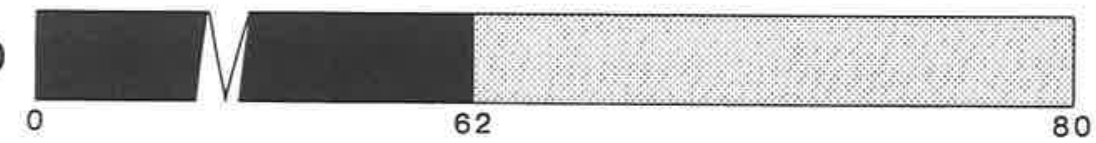

straightforward manner. In contrast, the assessment of morbidity and disability is much more arbitrary, and various methods have been used in the studies discussed here. As described in $\S 2.6$, Sullivan (1971) was the first to introduce a single indicator for life expectancy without morbidity and disability, called "active life expectancy", "health expectancy" or "disability-free life expectancy". Katz et al (1983), Colvez and Blanchet (1983) and Robine et al (1987) subsequently elaborated on the idea. This indicator is at the heart of the discussion about compression or decompression of morbidity. 
Colvez and Blanchet (1981) studied data from the continuing National Health Interview Survey for the period 1966-1976. This survey covers the non-institutionalized population of the United States. Using both long-term and short-term limitation of activity as indicators, they found a $37 \%$ increase in the number of disabled persons for that period versus a population growth of only $10 \%$. However, this increase in disability rates was more pronounced for those below the age of 65 than for the 65 -and-over age group. As expected, disability was more prevalent among the elderly, with more severe disability among men and less severe disability among women. Most of the increase in disability was caused by arthritis and rheumatism, heart conditions and hypertension, and diabetes.

Wilkins and Adams (1983) analysed Canadian health expectancy in the late 1970s, using data on both short-term and long-term activity restriction as well as institutionalization. Comparing health expectancy in 1978 to that in 1951, they found that life expectancy at birth had risen by 4.5 years for males and 7.5 years for females, but the number of expected years of disability-free life by only 1.3 and 1.4 years, respectively.

Verbrugge (1984) also used the United States Health Interview Survey. She described in detail the changes in various indicators between 1958 and 1981: selfrated health status, short-term disability associated with acute and chronic health problems (expressed as restricted activity days and bed disability days), and major and secondary limitations due to chronic conditions. Most of these indicators show rising morbidity for the middle-aged and the elderly since 1958, especially since 1970, with a greater increase found for restriction of activity than for bed disability and for chronic than for acute conditions. Among the elderly, hypertension, cardiovascular disease, musculoskeletal disorders and diabetes were mainly responsible for the rising morbidity.

Palmore (1986) drew different conclusions from his analysis of Health Interview Survey data. He could not demonstrate a clear improvement or deterioration in seven health indicators for non-institutionalized persons over 65 between 19611962 and 1980-1981; he did find, however, that they showed a consistent improvement when compared to trends in the same indicators for the whole population. 
Stout and Crawford (1988) used a different approach. They analysed data on all elderly patients who died in hospital after prolonged geriatric care in Belfast, Northern Ireland between 1954 and 1986. They found that during this period, the average age at admission rose by 0.24 years per year for females and 0.10 years per year for males, and that the median duration of hospitalisation increased by 5.59 days per year for females and 6.08 days per year for males. Life expectancy at birth rose continuously in Northern Ireland during this period, more for women than for men; similarly the continuous increase in active life expectancy (i.e. until terminal dependency sets in) was also greater for women than for men. However, although terminal dependency was postponed, the duration of terminal dependency increased, again more for women than for men. In 1986 , women spent $2.75 \%$ of their lifespan in long-term terminal care and men $1.84 \%$.

The findings of Winblad and Ljunggren (1988) were similar to those of Stout and Crawford. In Stockholm, Sweden, the mean age of women at admission for longterm care increased significantly between 1972 and 1986 and the trend for men was upwards. Both median duration of stay and the proportion of total lifespan spent in long-term care increased significantly for women and men.

Crimmins, Saito and Ingegneri (1989) made a thorough study of the trends in total life expectancy and disability-free life expectancy in the United States over the period 1970-1980. They used mortality and institutionalization data and disability indicators from the National Health Interview Survey. Two methods were used to calculate disability: the first counted long-term limitation of activity (in three grades of severity) and short-term disability, the second only bed disability. They concluded that the years added to life expectancy between 1970 and 1980 were predominantly years spent with a chronic disabling illness. However, most of this increased disabled life involved disability of a less severe degree rather than severe disability or bed disability, except for those above 85 years of age. Females live longer than males and their longer life is composed of more years free of disability, more years with both short and long-term disability and more years in institutions. 
Finally, Henderson, Goldacre and Griffith (1990) examined hospital admissions during the last year of life in the elderly population in the Oxford area. Between 1976 and 1985, there was an increase in the percentage of people who died in hospital, an increase in the admission rate and a decrease in the average duration of stay. All changes were small. Taken together, there was a slight increase in the median number of days elderly people spent in hospital in their last year. This was balanced by an increase in life expectancy at age 65 of one year in the course of the same period.

\subsection{Dutch data and methods}

As in other developed countries, mortality rates and life expectancies at birth and at various ages have been routinely available in the Netherlands since the last century. However, an impression of developments in morbidity over longer periods is more difficult to obtain.

Every three years since 1974, a sample of the adult Dutch population has been interviewed about various aspects of the quality of their life, including their personal health status.

Since 1981, a continuous Health Interview Survey has been conducted in the Netherlands; it includes more or less the questions on health asked in the abovementioned Quality of Life Survey. These questions deal with acute and chronic health problems and disability. Theoretically it should therefore be possible to study trends in subjective health in the period after 1974 .

Both during 1971-1972 and during 1986-1988 special surveys were organized to study in more detail the prevalence of disability in the Dutch population (CBS 1990). Many indicators seem to point to a slight worsening of the perceived health status as far as disability is concerned between these two periods, but the Central Bureau of Statistics insists that the comparison should not be made because of methodological differences between the two surveys. Therefore in this chapter no use will be made of this information.

In the Netherlands, everybody has his or her own family doctor. The percentage of population consulting these general practitioners in the past 3 or 12 months 
(including home visits by the general practitioner) and the percentage of various subgroups of the Dutch population consulting medical specialists, both of which have been monitored since 1974, can be considered indicators of morbidity. Since 1981, a question on the annual number of visits to general practitioners and medical specialists has been included in the Health Interview Survey as well.

Although nation-wide registration of all hospital data is a comparatively recent process in the Netherlands, some hospital statistics have been recorded for fifteen years. In this chapter we have used the number of male and female discharged hospital patients in 5-year age groups between 60 and 84 years of age. The group 85 years-and-older was excluded because of the small numbers involved, because it cannot be subdivided into 5 -year age groups and because there is a tendency to avoid medical interventions in hospital and to keep these very old people at home or refer them to a nursing home.

Another hospital indicator that has been examined is the mean duration of hospitalization of elderly patients over the period 1976-1988. Taken together, the two hospital indicators give an impression of the total number of inpatient days.

In the Netherlands, nursing homes are institutes for long-term geriatric care for those elderly patients who are too ill or handicapped to remain at home or in an old-people's home but who do not need the specialized care given in hospitals. At present, there are slightly more than 50,000 beds available in Dutch nursing homes for a population of nearly 15 million.

For the period 1972-1987, the annual number of nursing home admissions, the average length of stay and the average age at admission were determined.

\subsection{Results}

In figure 2.4, the development of life expectancy at birth and at 65 years is shown for Dutch males and females for the period 1951-1985.

For females, there was a continuous rise in both, whereas males fared much worse. However, since the height of the Dutch epidemic of myocardial infarctions among males in 1972, male life expectancy has exhibited an increase. 
Obviously, there is neither a slowing down of the rise in life expectancy although the picture is less clear for males - nor a narrowing of the gap between males and females, as predicted by Fries (Fries 1984).

A comparative analysis has been made of the answers to the questions in both Dutch surveys, i.e. the Quality of Life Survey and the Health Interview Survey (van den Berg and van den Bos 1989). Due to changes in formulation of the questions and surveying techniques, comparability appears to be limited. All that can be said about perceived health status, expressed according to sex and various age groups, is that there has been no clear improvement or deterioration. In particular the percentage of people over 65 years of age who judged their health status to be "bad" or "sometimes good and sometimes bad" (approx. 16\%) remained more or less constant between 1970 and 1989 (Swinkels 1986b; Swinkels 1990).

The percentage of the elderly population that consulted the family doctor in one year and the annual number of visits to the family doctor have remained stable in recent years. These data (not shown here) are based on the Health Interview Survey (Swinkels 1990) and therefore cover the period 1981-1989 only.

The Quality of Life Survey (Swinkels 1986a) contained similar questions, but they were limited to consultations with the general practitioner in the past 3 months. Likewise, there has been no discernible change since 1974.

Similar questions about outpatient visits to medical specialists were asked in both surveys . No clear changes have occurred since 1974, except for a slight upward trend since 1981 in the percentage of elderly patients who consulted a medical specialist (figure 5.2).

When the numbers of discharged hospital patients in the period 1975-1986 are analysed (CBS 1986; CBS 1989), a different picture emerges (figure 5.3). The hospitalisation of elderly patients clearly increased during this period, and the older the patients, the greater the increase. 
Figure 5.2 Percentage of the Dutch population consulting a medical specialist within one year, 1981-1989

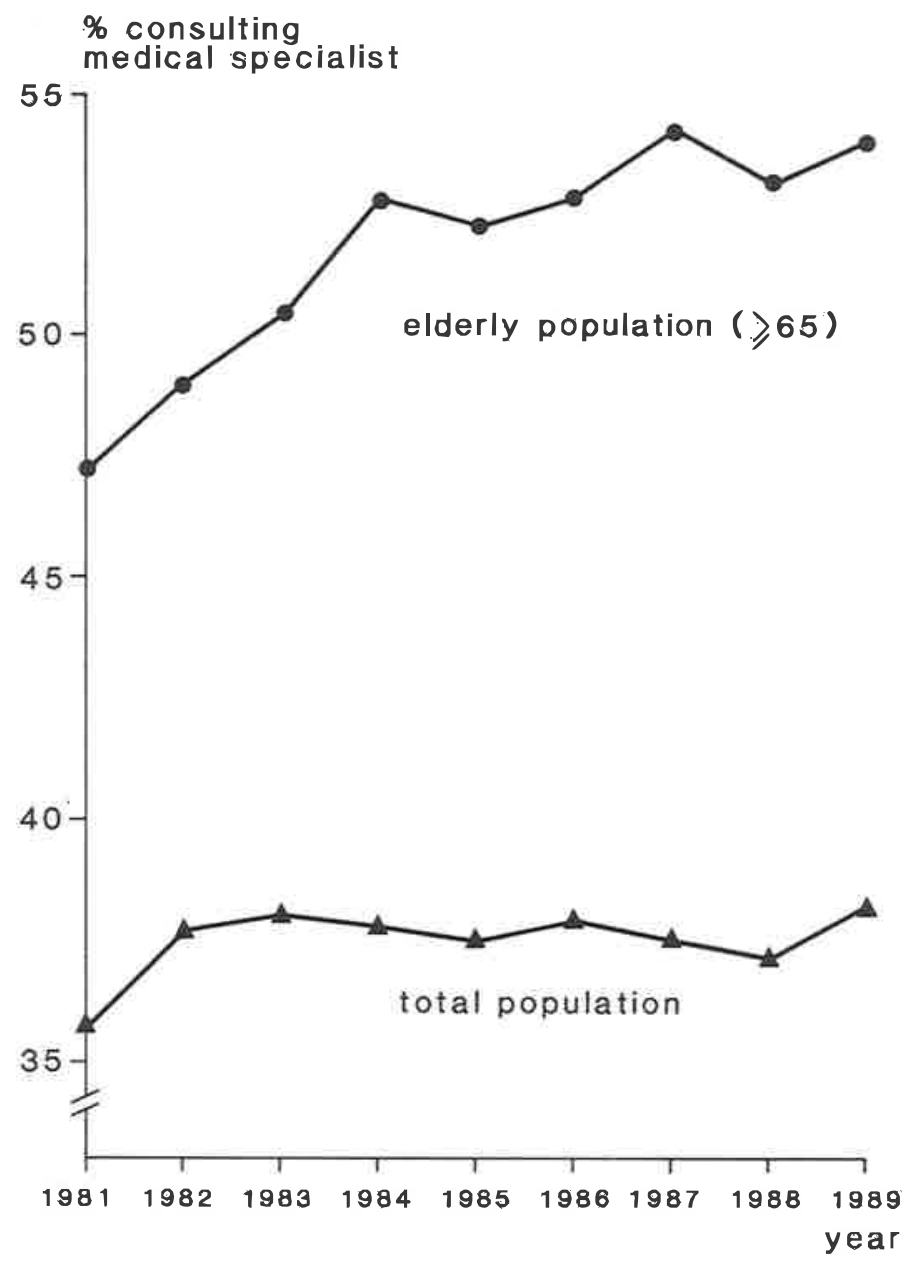

Source: Swinkels 1990

All younger age groups exhibited decreasing admission rates during the same period (Hoogendoorn 1989).

However, the increasing hospital admission rates for elderly people are partially counteracted by a declining mean duration of stay, possibly at an even faster rate than that for the population as a whole (SIG 1976-1988). This is shown in figure 
5.4. Although declining, the mean duration of stay is still longer for the elderly, and especially the very old, than for younger age groups of the population.

Figure 5.3 Annual number of discharged hospital patients per 1000 males/females for each age group, $1975-1986$

\section{number of patients per}

1000 males/females

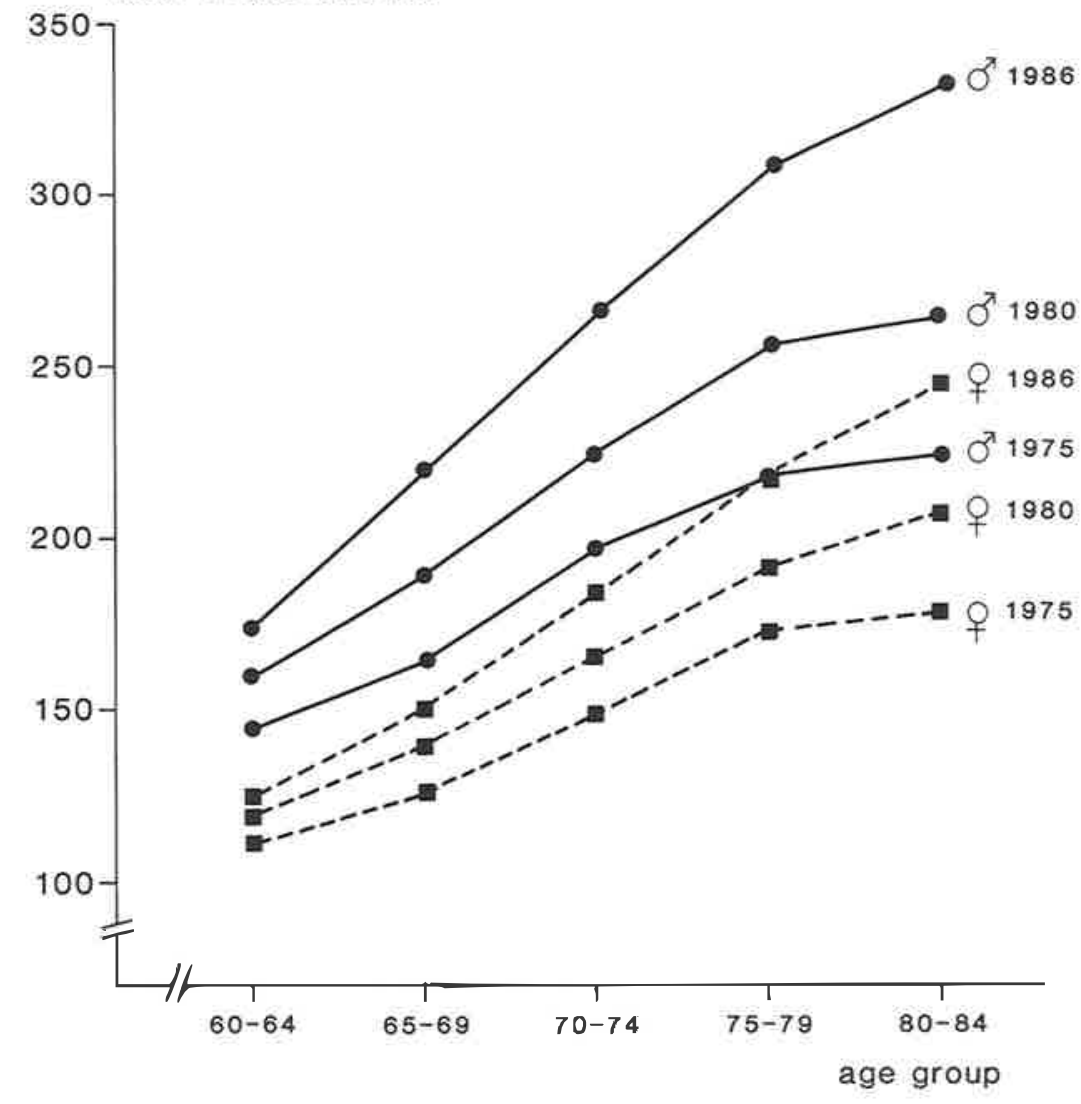

Source: CBS 1986; CBS 1989 
Fiqure 5.6 Average duration of stay in Dutch hospitals, 1976-1988, according to age group

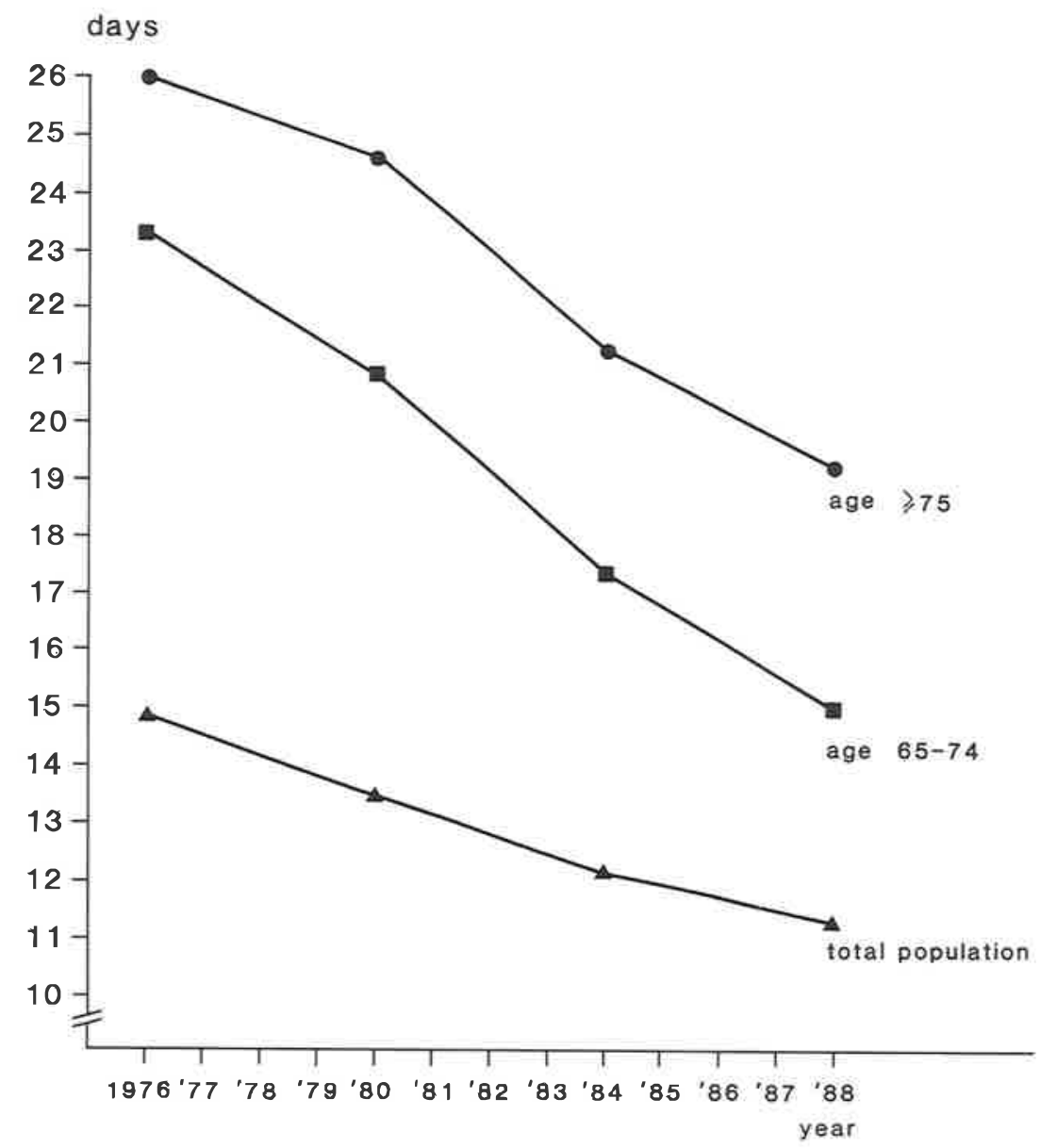

Source: SIG 1976-1988

Some trends in nursing home data are shown in figures 5.5-7 (CBS 1974; CBS 1980; CBS 1986; CBS 1989).

The number of inpatient days increased constantly (figure 5.5). The increase between 1972 and 1987 was $63 \%$, whereas the number of people in the age group admitted to nursing homes ( $>75$ years) rose by only $50 \%$ in the same period.

The number of admissions has also increased, but only from 31,344 in 1972 to 39,779 in 1987 , i.e. $27 \%$. 
Figure 5.5 Percentage increase in the number of inpetient days in Dutch nursing homes compared to percentage increase in the Dutch population over 75 years, 19721987

$\%$ increase

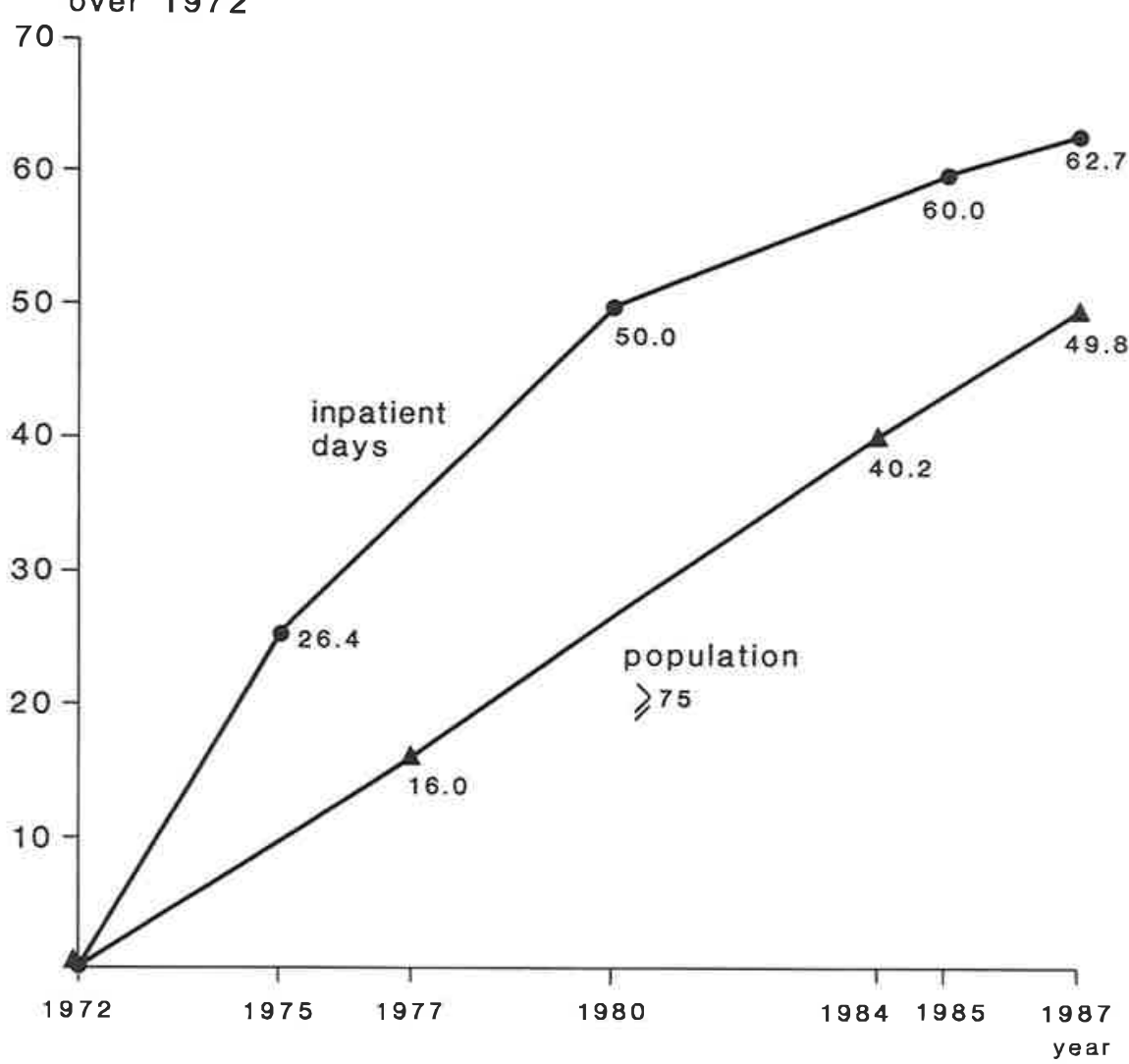

Source: CBS 1974; CBS 1980; CBS 1986; CBS 1989

Therefore the average duration of stay increased in this period from 351 days to 450 days (figure 5.6).

The median age at admission has increased slowly but steadily (figure 5.7) (SIG 1990). Not only the general population is ageing but also the nursing home population, as can be seen in table 5.1 om page 129 (NZI 1986; NZI 1989). 
Figure 5.6 Average duration of stay in Dutch nursing homes, 1972-1987

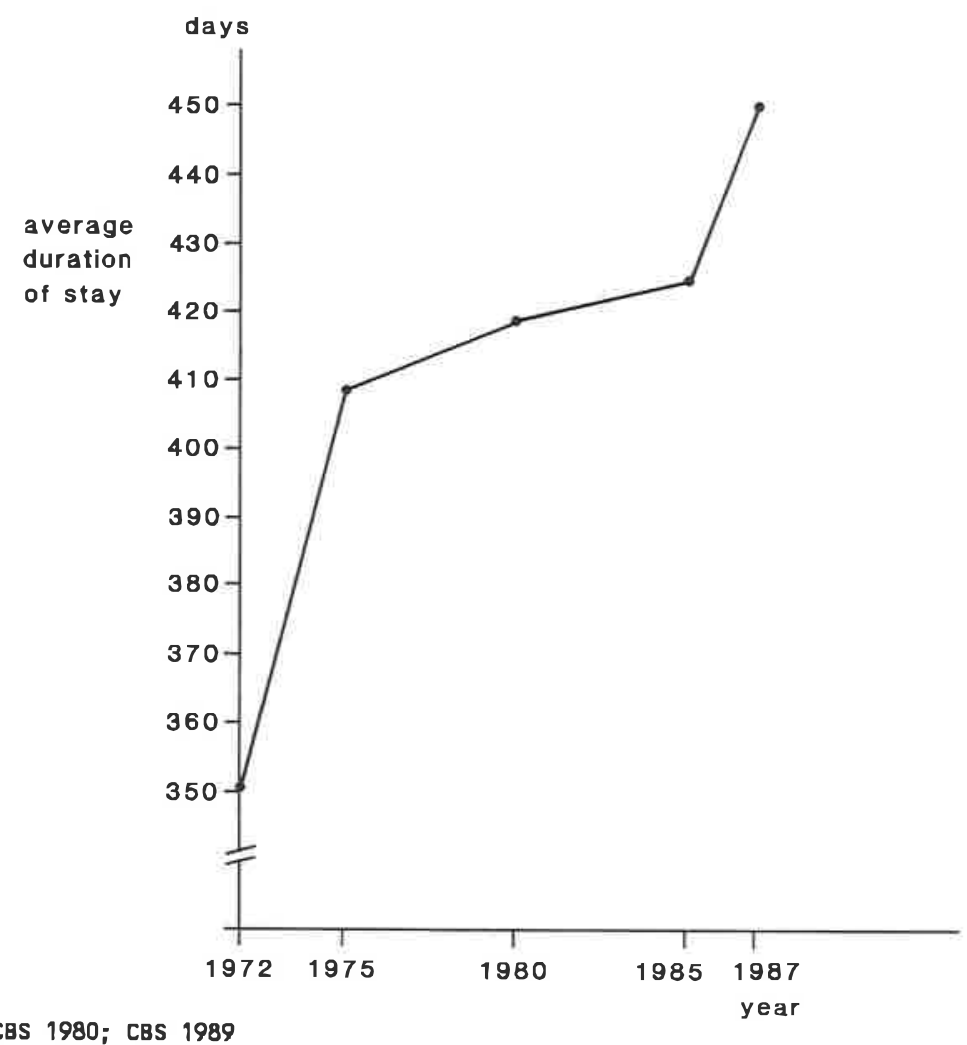

Source: CBS 1980; CBS 1989

\subsection{Discussion}

When one tries to evaluate whether compression or decompression of morbidity is taking place in the Netherlands, it becomes apparent that there are no clearcut answers to all of the questions. Whereas the subjective health status of the elderly and their use of primary health care have remained remarkably constant over the years, their use of institutional and specialist care seems to have grown. Their hospital admission rate is increasing (although balanced by a decreasing duration of stay per admission), medical specialists are consulted more of ten, and more time is spent in nursing homes than is warranted by the growth of this segment of the population. 
Figure 5.7 Median age at admission of somatic and psycho-geriatric patients in Dutch nursing homes, by sex, 1981-1989

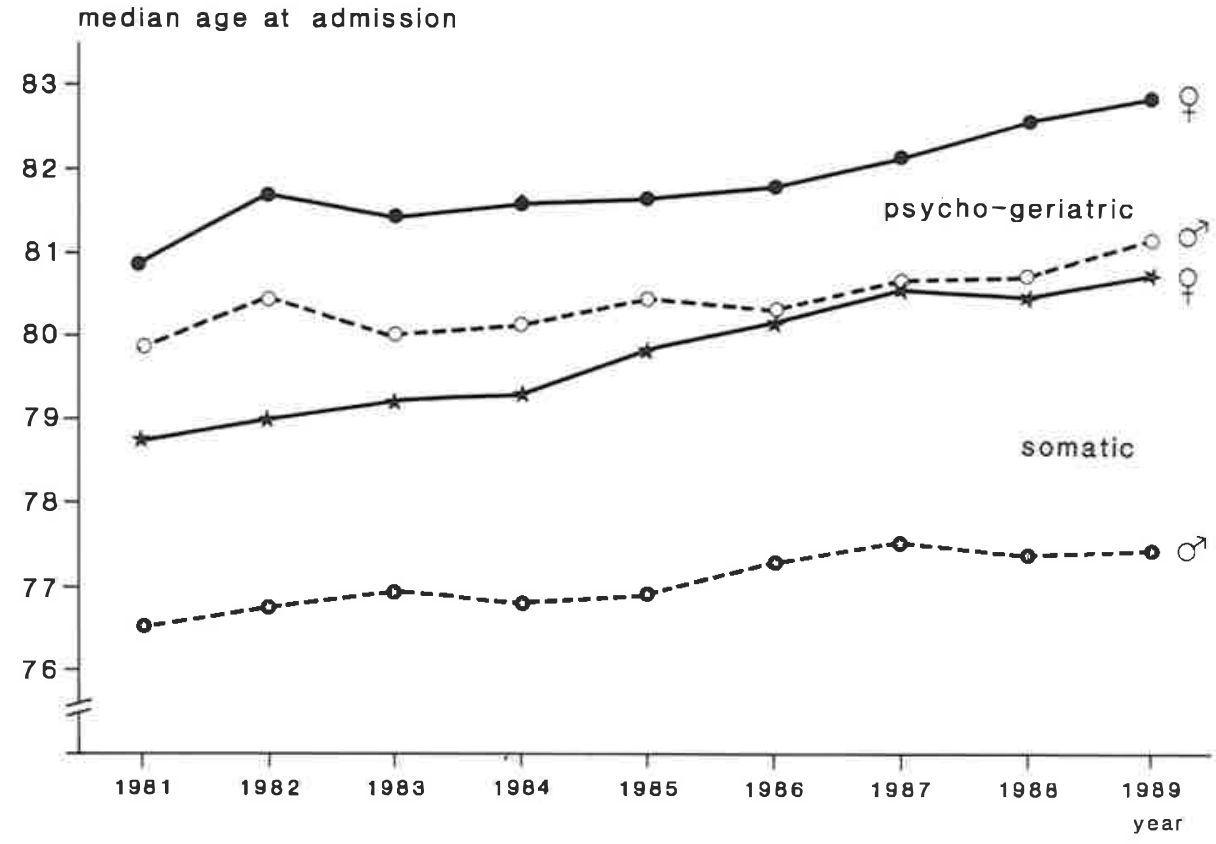

Source: SIG 1989

The use of medical consumption as a measure of morbidity and quality of life in the population has to be handled with caution: this consumption can be influenced by other factors such as the supply of health care facilities, financial thresholds, government policy or socio-cultural factors. Some, therefore, do not feel at all at ease using this type of health indicator to analyse morbidity trends. Still, one could conclude that, although life expectancy at birth and at age 65 has been increasing, the period of disability (mainly among the elderly) has also been increasing. No attempt has been made here to subdivide disability into milder and more severe forms. Because we are dealing largely with chronic morbidity, present trends will continue at least for some time into the future. 
Table 5.1 Dutch nursing home population according to age group (in $\%$ ), 1981-1988

\begin{tabular}{l|rrrrrrrr}
\hline 日ge group & 1981 & 1982 & 1983 & 1984 & 1985 & 1986 & 1987 & 1988 \\
\hline $0-64$ yrs & 11.13 & 10.88 & 10.37 & 9.90 & 9.61 & 9.14 & 8.69 & 8.51 \\
$65-69$ yrs & 6.10 & 5.76 & 5.61 & 5.39 & 5.40 & 5.33 & 5.26 & 5.26 \\
$70-74$ yrs & 11.40 & 10.92 & 10.73 & 10.46 & 10.00 & 10.05 & 9.58 & 9.49 \\
$75-79$ yrs & 18.87 & 18.46 & 18.70 & 18.61 & 18.54 & 18.54 & 17.92 & 17.48 \\
$80-84$ yrs & 22.65 & 23.27 & 23.45 & 23.79 & 23.92 & 24.03 & 24.33 & 24.28 \\
$85-89$ yrs & 18.61 & 19.08 & 19.34 & 19.82 & 20.30 & 20.38 & 21.15 & 21.21 \\
$90-94$ yrs & 9.08 & 9.33 & 9.33 & 9.62 & 9.69 & 9.86 & 10.23 & 10.79 \\
$\geq 95$ yrs & 2.12 & 2.31 & 2.48 & 2.42 & 2.54 & 2.67 & 2.84 & 2.98 \\
\hline Totel & 100.00 & 100.00 & 100.00 & 100.00 & 100.00 & 100.00 & 100.00 & 100.00 \\
\hline
\end{tabular}

Source: NZI 1987; NZI 1990

From the other studies mentioned in $\S 5.1$, it is not yet clear whether total life expectancy at birth is rising faster than active life expectancy at birth or not, i.e. to what extent are the extra years allotted to the population spent in good health or bad health. Further research into the components of active life expectancy and international cooperation in this field can help to clarify this matter. No time trends are available yet for the Dutch variant of this indicator, described in $\S 2.6$, because earlier data on some components are lacking. Decreasing hospitalization rates for those below 60 years and the increasing average age at admission to nursing homes, coupled with the more or less stable subjective health status for all age groups, seem to point to an increasing active life expectancy in the Netherlands, however. If this is indicative of a decompression of morbidity, then scenario D (figure 5.1) seems to be the most probable outcome for the future, partly as a result of present prevention strategies.

The increase in life expectancy at birth and for older age groups is only partially due to preventive and medical measures, but insofar as preventive and curative health care have a role to play, it may be more prudent to aim at the improvement of the quality of the remaining years than at the prolongation of life. "Every man desires to live long, but no man would be old" (Jonathan Swift, 
Thoughts on various subjects, 1706). Thus the potential compression or expansion of morbidity caused by preventive measures should be taken into account. 


\section{LITERATURE}

van den BERG J, van den BOS GAM. The (measurement of the) prevalence of chronic conditions, 1974-1987 (in Dutch, with summary in English). Maandbericht Gezondheidsstatistiek $1989 ; 8(3): 4-21$

CBS (Netherlands Central Bureau of Statistics)/Ministry of Public Health and Environmental Hygiene. Compendium Health Statistics of the Netherlands 1974 (bilingual DutchEnglish). The Hague: Staatsuitgeverij, 1974.

CBS/Ministry of Public Health and Environmental Hygiene. Compendium Health Statistics of the Netherlands 1979 (bilingual Dutch-English). The Hegue: Staatsuitgeverij, 1980.

CBS/Ministry of Welfare, Health and Cultural Affairs. Compendium of Health statistics in the Netherlands 1986 (bilingual Dutch-English). The Hague: Staatsuitgeverij, 1986.

CBS/Ministry of Welfare, Health and Cultural Affairs. Vedemecum Health Statistics of the Netherlands 1989 (bilingual Dutch-English). The Hague: SDU-uitgeverij, 1989.

CBS/NIMAwO. Lichamelijke beperkingen bij de Nederlandse bevolking, 1986/1988 (in Dutch). The Hague: SDU-uitgeverij, 1990.

COLVEZ A, BLANCHET M. Disability trends in the United States population 1966-76: enalysis of reported causes. Am J Public Health 1981;71:464-71.

COLVEZ A, BLANCHET $M$. Potential gains in life expectancy free of disability: a tool for health planning. Int J Epidem 1983; 12:224-9.

CRIMMINS EM, SAITO $Y$, INGEGNERI D. Changes in life expectancy and disability-free life expectancy in the United States. Pop and Dev Rev 1989;15:235-267.

FRIES JF. Aging, natural death and the compression of morbidity. N Engl J Med $1980 ; 303: 130-5$.

FRIES JF. The compression of morbidity: miscellaneous comments about a theme. The Gerontologist $1984 ; 24: 354-9$.

FRIES JF, GREEN LH, LEVINE S. Health promotion and the compression of morbidity. Lancet $1989 ; i: 481-3$.

HENDERSON J, GOLDACRE MJ, GRIFFITH M. Hospital care for the elderly in the final year of life: a population based study. Br Med J 1990;301:17-9.

HOOGENDOORN D. Admission and bed occupation in hospitals before and after the start of budgeting (in Dutch, with summary in English). Ned Tijdschr Geneeskd 1989; 133:156-61.

KATZ S, BRANCH LG, BRANSON MH, PAPSIDERO JA, BECK JC, GREER DS. ACtive life expectancy. N Engl J Med 1983;309:1218-24.

NZI (National Hospital Institute of the Netherlands). De intramurale gezondheidszorg in cijfers per 1 januari 1986 (in Dutch). Utrecht (the Netherlands): NZI, 1987.

NZI. De intramurale gezondheidszorg in cijfers per 1 januari 1989 (in Dutch). Utrecht (the Netherlands): NZI, 1990.

PALMORE EB. Trends in the health of the aged. The Gerontologist 1986;26:298-302.

ROBINE JM, BROUARD N, COLVEZ A. The disability free life expectancy (DFLE) indexes, comprehensive indexes of population health status (in French, with summary in English). Rev Epidém et Santé Publ 1987;35:206-24. 
SCHNEIDER EL, BRODY JA. Aging, natural death and the compression of morbidity: another view. N Engl J Med 1983;309:854-5

SCHNEIDER EL, REED JD. Life extension. N Engl J Med 1985;312:1159-68.

SIG (Dutch Centre for Health Care Information). Jaerboeken Landelijke Medische Registratie 1976-1988 (in Dutch). Utrecht (the Netherlands): SIG, 1976-1988.

SIG. Jaarboek Verpleeghuizen 1989 (in Dutch). Utrecht (the Netherlands): SIG, 1990.

STOUT RH, CRANFORD V. Active-life expectancy and terminal dependency: trends in longterm geriatric care over 33 years. Lancet 1988; i:281-3.

SULLIVAN DF. A single index of mortality and morbidity. HSMHA Health Reports $1971 ; 86: 347-54$.

SHINKELS H. Trends of medical consumption in 1974-1984 (in Dutch, with summary in English). Maandbericht Gezondheidsstatistiek 1986a;5(2):5-19.

SWINKELS H. Trends of health indicators, 1970-1984 (in Dutch, with summary in English). Maandbericht Gezondheidsstatistiek 1986b;5(7):5-15.

SWINKELS H. Trendfigures Netherlends Health Interview Survey, 1981-1989 (in Dutch, with summary in English). Maandbericht Gezondheidsstatistiek 1990;9(9):5-24.

VERBRUGGE LM. Longer life but worsening health? Trends in health and mortality of middleaged and older persons. Milbank Memorial Fund Quarterly 1984;62:475-519.

HILKINS R, ADAMS OB. Health expectancy in Canada, late 1970s: demographic, regional and social dimensions. Am J Public Health 1983;73:1073-80.

WINBLAD B, LJUNGGREN G. Life expectancy and planning care for the elderly. Lancet $1988 ;$ i i : 1313 


\section{COMPETING CAUSES OF DISEASE AND DEATH}

\subsection{Introduction}

Usually, the impact of preventive measures against risk factors is assessed with disease-specific indicators: incidence rate for stroke, mortality rate for breast cancer, etcetera. It is assumed that elimination of part of a health problem will mean that the overall health situation will improve accordingly. For some interventions, this is undoubtedly true: the degree to which poliomyelitis morbidity is decreased is comparable to the resulting increase in the health status of the population. It is disturbing, however, that this is not true for interventions aimed at postponement or partial elimination of those health problems of older age that can be lethal. The two most important groups of diseases in this category, and indeed in the field of health as a whole, are cardiovascular disease and cancer. To assess our success in preventing these diseases, we should use the "ultimate" indicators of overall morbidity and mortality and their derivatives: life expectancy and number of (if possible quality-adjusted) life years gained. It would be no use to eliminate part of one health problem if that means that another and maybe more serious health problem will increase in magnitude: this is substitution or competition between causes of disease and death.

For relatively rare diseases the ultimate indicators cannot be used: the effects of prevention on overall mortality will be swamped by other causes of death. The only approach is to measure the decrease in the incidence or specific mortality for such a disease. This is the case for cervical cancer, for example: even if mass screening could lead to total elimination of the disease (quod non), it would amount to a decrease in overall female mortality of less than $0.5 \%$.

Even a rather common disease such as breast cancer is a borderline case. In the Netherlands, breast cancer was responsible for $5.6 \%$ of all female deaths in 1987 . If $18 \%$ of all breast cancer deaths could be prevented by a mass screening programme (an optimistic figure, see $\S 3.7$ ), that would mean $1 \%$ (18\% of $5.6 \%$ ) of total female mortality; this might - with some difficulty - become visible in general mortality statistics. 
Therefore, only rapid large drops in the frequency of major diseases, e.g. lung cancer in males or coronary disease, would show up in national mortality statistics, but generally speaking health problems have to be combined into larger disease categories if one wants to use them to explain trends in total mortality. Only two categories have sufficient size for this purpose: cardiovascular disease and cancer, but then the difficulty is to attribute improving trends in these groups of diseases to a specific prevention programme.

However, we do not need national statistics to prove or disprove the effect of prevention programmes. It is possible to use the results of community trials with study groups and control groups. These trials will be discussed in $\S 6.3$.

\subsection{Demographic models}

Demographers and mathematicians were the first to grapple with the theoretical concept of competing causes of death (Keyfitz 1977; Wong 1977; Tsai et al 1978; Manton and Poss 1979; Manton 1982). They studied the number of life years gained by (partially or completely) eliminating causes of death such as cancer, cardiovascular disease and accidents. The theoretical health benefits of the elimination of a major health problem were found to be very limited, because the risks for other causes of death would then rise quickly. This can be explained by the fact that the morbidity and mortality patterns in the industrialized world are dominated by chronic degenerative diseases that occur predominantly in the elderly and increase exponentially with age. This is illustrated in figure 6.1 using the relationship between cancer incidence and age. Such graphs can also be made for cancer mortality, incidence and mortality of cardiovascular disease and prevalence of dementia. For diseases that occur more frequently in younger age groups, such as traffic accidents or some infectious diseases, the gain in life expectancy for the saved individual will be much greater; but these causes of death are much less common in the developed world so that the gain for the population is much less impressive (see $\S 3.3$ ).

Another problem is the relationship between various causes of death: for example, are people who have been saved from developing cancer more suscepti- 
Fiqure 6.1 Cancer incidence in the southeastern part of the Netherlands in 1975-1986 according to age category and sex (excluding skin cancer, ICD 173)

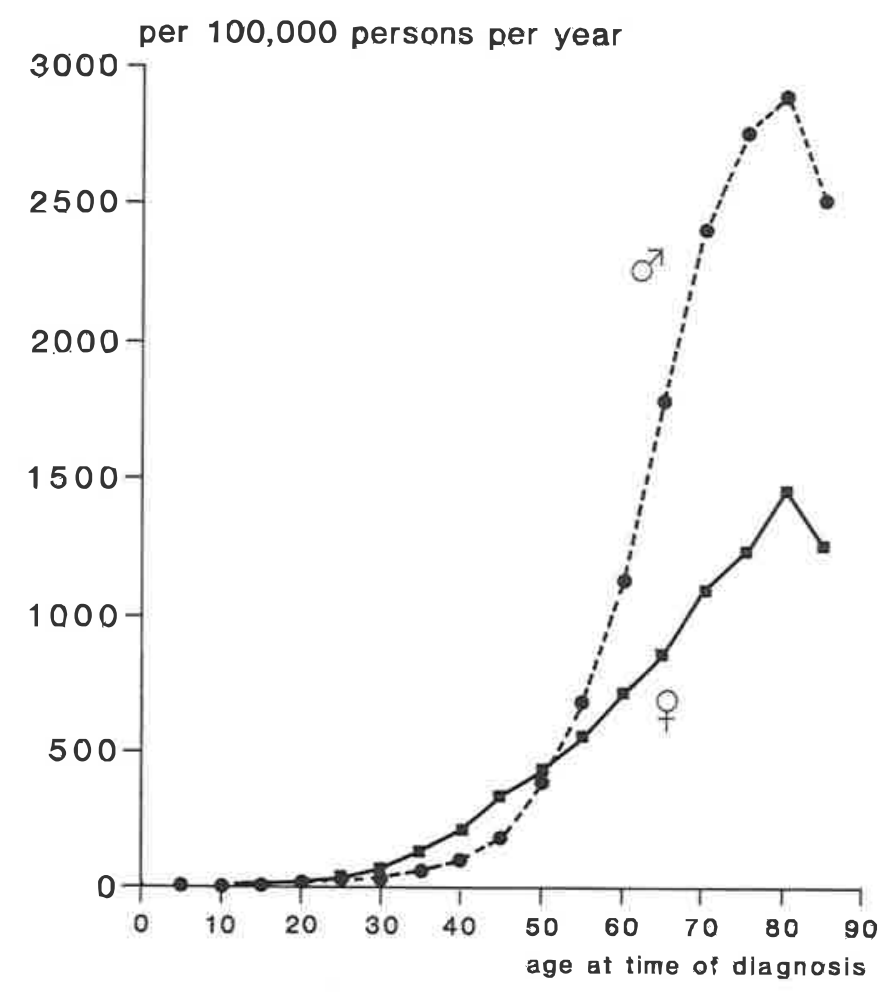

Source: Coebergh et al 1990

ble to heart disease than the average population? The demographers realized that there was probably a certain interdependence between causes of death but assumed independence of causes of death for their models. Interdependence of the causes of death would further diminish the already small effects of eliminating one cause of death. 


\subsection{Results of community trials}

In the 1970s and 1980s, the results of large-scale and lengthy community trials of primary and secondary prevention of cancer and cardiovascular disease were published. In such trials, one can compare the specific and total (all-cause) morbidity and mortality for the study and control groups. Often in the past (and even today), no figures on all-cause mortality were presented in the reports on these trials. But when they were, they should have given cause for concern! Most cardiovascular intervention trials were quite successful in diminishing cardiovascular morbidity and mortality but had little or no influence on total mortality (Miettinen et al 1985; Tuomilehto el al 1986; Olson 1986; Oliver 1986; Salonen 1987; McCormick and Skrabanek 1988; Hiroyasy et al 1989; Appels et al 1989; Collins et al 1990; Muldoon et al 1990). Exceptions to this rule are scarce (MacMahon et al 1986 and Hebert et al 1988: both on treatment of hypertension; MRFIT Research Group 1990). This can only mean that non-cardiovascular mortality increased relatively during the trial. A programme of regular health checkups and relevant interventions for middle-aged individuals showed no overall benefit in mortality (Friedman et al 1986). The same phenomenon could be observed after trial screening programmes for breast cancer although less clearly so (Andersson et al 1988; Tabar et al 1989; Roberts et al 1990).

Now this is uncomfortable information. Prevention programmes are supposed to yield quantitative and/or qualitative health benefits, but most population programmes against cardiovascular disease and cancer seem to end in a mere exchange of one disease category for another. It seems that Issawi's Law is applicable here as well: "In a closed system, the quantity of evil remains constant" (Issawi 1973). How can this be explained?

For the lack of impact on total morbidity and mortality, various explanations have been given: possible side-effects of the drugs used to bring down the serum cholesterol level or the blood pressure (Miettinen 1985 et al; Anonymous 1988; Appels et al 1989; Anonymous 1989), other - as yet unknown - dangers of lowering the serum cholesterol level (Muldoon et al 1990), just chance because there is no logical explanation (Blackburn 1989; Rose and Shipley 1990) or the 
above-mentioned fact that a decrease in total mortality due to breast cancer screening would not show up in national statistics (Tabar et al 1989).

However, these explanations miss the point.

Firstly, the phenomenon of competing causes of death can also be observed when no drugs are given and the trial consists only of life-style adaptations in smoking, nutrition or physical exercise. It can even be observed in naturally occurring mortality trends (see $\$ 6.4$ ).

Secondly, chance will play a role once or twice but not as consistently as seen in most of these trials. And although a biological explanation for increasing mortality due to cancer and accidents during cardiovascular prevention programmes may be impossible to find, the statistical explanation for the increase in other causes of death when one cause of death is partially eliminated is easily understood, even without mathematic models or calculations.

Thirdly, although it is agreed that the results of specific prevention programmes can almost never be detected in national mortality statistics, that is what trial results are for: if a reduction in cause-specific mortality can be proven in these trials, so can the fact that total mortality remains more or less the same.

\subsection{Discussion}

Apart from demographic research and the results of community prevention trials, there are other facts that point in the direction of competing causes of death as an explanation for shifts in the morbidity and mortality patterns: i.e. the observed trends in specific mortality rates and the role of cholesterol.

In the Netherlands, the age-adjusted incidence and mortality rates for cardiovascular disease have been decreasing for quite some time, among males since 1972 and among females for an even longer period (see figure 2.3 ). This reduction was explained by an improvement in the cardiovascular risk factor profile for the Dutch population in the preceding period: less smoking, healthier nutrition, more physical exercise and more effective and faster curative interventions. In general, this improvement indeed took place, except for the smoking behaviour of women. However, the mortality rate for stroke has been decreasing steadily 
for a much longer period without the benefit of an improving risk factor profile and therefore remains unexplained.

Age-adjusted incidence and mortality rates for all cancers combined have remained more or less constant in the Netherlands for the past 30 years. Most other European countries have a similar pattern of stable or even rising age-adjusted cancer mortality rates and decreasing age-adjusted cardiovascular mortality rates. Only in Austria, West-Germany, Finland, Luxemburg, Sweden and Switzerland are both rates decreasing, according to the HFA database of the WHO in Copenhagen. The result of a decreasing cardiovascular mortality rate and a constant cancer mortality rate is presented in figure 6.2 as the share of both causes of death in total mortality. Cancer is starting to replace cardiovascular disease as the main cause of death.

Figure 6.2 Percentage of total mortality for cardiovascular disease and cancer in the Netherlands, 1960-1988

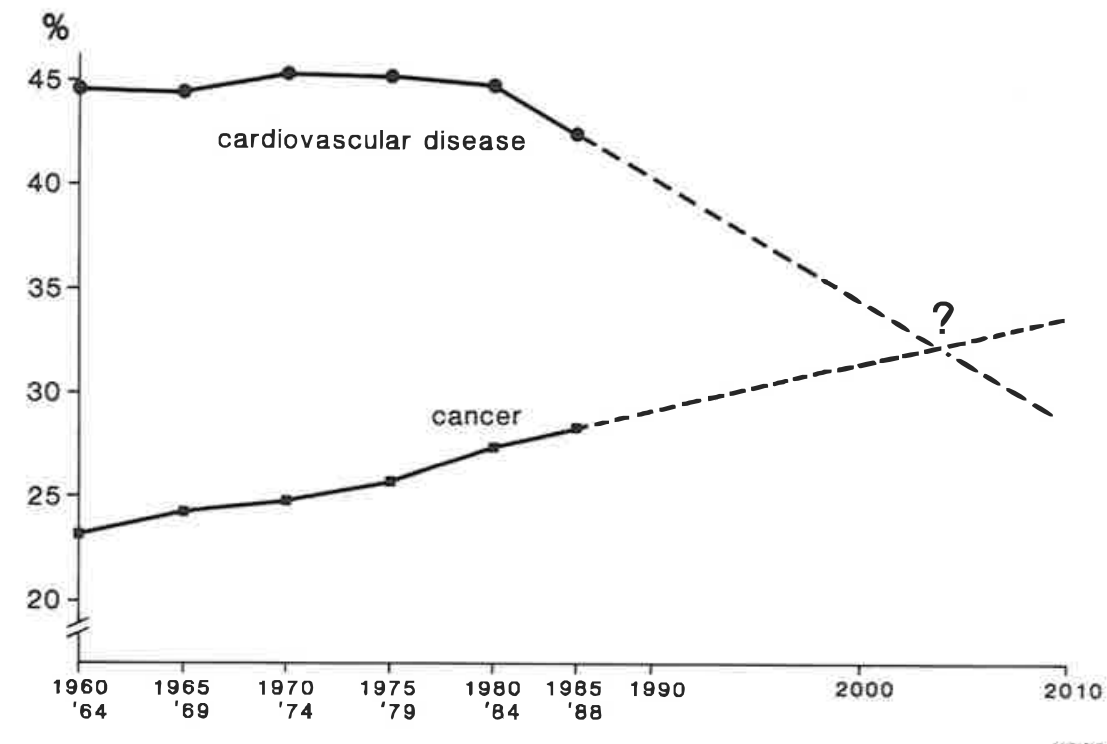

Source: annual overviews of causes of death (CBS) 
The same trend has been noted in the United States (Breslow and Cumberland 1988). This is another illustration of competing causes of death. Cardiovascular disease and cancer play the main roles here because all other causes of death are much less important: these other causes, which account for approximately $30 \%$ of all deaths in the Netherlands, are spread over many different and relatively unimportant groups. The biggest one is respiratory diseases which again is a heterogeneous group.

The demographers usually assumed independent risks for various diseases and causes of death in their models, but this is of ten not true in practice. Hypertension may be a specific risk factor for cardiovascular disease, but smoking is a risk factor for several groups of diseases; the same applies for unhealthy dietary habits. Cholesterol is a case apart. It is one of the most important risk factors for cardiovascular disease but its connection with cancer is unclear. Low serum cholesterol levels have been associated with higher cancer incidence and mortality (Anonymous 1989; Isles et al 1989; Blackburn 1989; Winawer et al 1990). Does cholesterol protect against cancer or do undiagnosed cancers cause a low cholesterol level? It is probably neither of these explanations but this is one more illustration of competing causes of death: a lower risk for cardiovascular disease means a higher risk for cancer.

Competition of causes of death means that a reduction (through prevention programmes or unexplained) in the cause-specific mortality rate for a major cause of death will lead to a rising mortality rate for other causes of death. This phenomenon, which at least to some extent does appear to occur - although mainly in older age groups - has an adverse effect on cancer and cardiovascular prevention programmes because it decreases (but does not necessarily eliminate) the number of healthy life years that one had hoped to gain with preventive measures. If one fears cancer as a cause of death more than cardiovascular disease, this would be an argument against community interventions against cardiovascular risk factors and for cancer prevention programmes. At the population level, it would thus be possible to some degree to substitute cardiovascular deaths for cancer deaths and thus change the trends shown in figure 6.2 (Wassersug 1988). Of course, it is not the diagnosis on the death certificate that is important, but the length and the quality of the period of morbidity preceding death. 
Cigarette smoking is a case apart. It is an important risk factor for both cardiovascular disease and some types of cancer (see table 3.2), and a further decline in smoking prevalence could lead to a reduction in cardiovascular and cancer mortality, with less or no competition between the two causes of disease and death. This may be the explanation for the slight (but not significant) reduction in total mortality found in the MRFIT study (MRFIT Research Group 1990), although in that case it is hard to explain the higher mortality for lung cancer in the intervention group. However, the resulting increase in life expectancy might in turn lead to a rising prevalence of non-lethal old-age morbidity such as dementia (Ineichen 1987; Jorm and Korten 1988; STG 1990), in other words a decompression of morbidity and another example of Issawi's Law.

In conclusion our review of competition between causes of death has revealed that:

- it exists but is not (yet) completely understood; therefore, further research is needed to quantify its effects.

- it might undo some or most of the results of the cancer and cardiovascular prevention programmes discussed in chapter 3; therefore, we must take this phenomenon into account when discussing the efficiency of prevention programmes and the setting of priorities in chapter 7 .

- it should not obscure the fact that the preceding morbidity and quality of life are more important than the ultimate cause of death. 


\section{LITERATURE \\ ANDERSSON I, ASPEGREN K, JANZON L et el. Memmogrephic screening end mortality from breast cancer: the Malmö manmographic screening trial. Br Med J 1988;297:943-8.}

ANONYMOUS. Primery prevention of ischeemic heart disease with lipid-lowering drugs [Editorial]. Lancet 1988; i:333-4.

ANONYMOUS. Secondary prevention of coronary disease with lipid-lowering drugs [Editorial]. Lancet 1989; i:473-4.

APPELS A, OTTEN F, STURMANS F, MULDER P, SCHUURMAN J. KRIS fol!ow-up studie V; effecten van de behandeling van bloeddruk, serum cholesterol en glucosetolerantie (in Dutch, with sumary in English). T Soc Gezondheidsz 1989;67:96-9.

BLACKBURN H. Population strategies of cardiovascular disease prevention: scientific base, rationale and public health implications. Annals of Medicine 1989;21:157-62.

BRESLOW L, CUMBERLAND WG. Progress and objectives in cancer control. JAMA 1988; 259: 16904.

COEBERGH JWM, VERHAGEN-TEULINGS MT, CROMMELIN MA, BAKKER D, van der HEIJDEN L. Trends in cancer incidence in Southeast North-Brabant and North Limburg in the period 1975-1986; report from the $1 \mathrm{KZ} / \mathrm{SOOZ}$ cancer registry (in Dutch, with summary in English). Ned Tijdschr Geneeskd 1990; 134: $754-60$.

COLLINS R, PETO R, MacMAHON 5 et al. Blood pressure, stroke, and coronary heart disease; part 2, short-term reductions in blood pressure: overview of randomised drug trials in their epidemiological context. Lancet 1990;335:827-38.

FRIEDMAN GD, COLLEN MF, FIREMAN BH. Multiphasic health checkup evaluation: a 16-year follow-up. J Chron Dis 1986;39:453-63.

HEBERT PR, FIEBACH NH, EBERLEIN KA, TAYLOR JO, HENNEKENS CH. The community-based randomized trials of pharmacologic treatment of mild-to-moderate hypertension. Am J Epidemiol 1988; 127:581-90.

HIROYASY I, JACOBS DR, MENTWORTH D, NEATON JD, COHEN JD. Serum cholesterol levels and six-year mortality from stroke in 350,977 men screened for the Multiple Risk Factor Intervention Trial. N Engl J Med 1989;320:904-10.

INEICHEN B. Measuring the rising tide: how many dementia cases will there be by 2001? Br J Psychiatry 1987; 150:193-200.

ISLES CG, HOLE DJ, GILLIS CR, HAUTHORNE VM, LEVER AF. Plasma cholesterol, coronary heart disease, and cancer in the Renfrew and Paisley survey. Br Med J 1989;298:920-4.

ISSAWI CP. Issawi's laws of social motion. Hewthorne Publications, 1973.

JORM AF, KORTEN AE. A method for calculating projected increases in the number of dementia sufferers. Aust NZ J Psychiatry 1988; 22:183-9.

KEYFITZ N. What difference would it make if cancer were eradicated? An examination of the Taeuber paradox. Demography 1977;14:411-8.

MacMAHON SH, CUTLER JA, FURBERG CD, PAYNE GH. The effects of drug treatment for hypertension on morbidity and mortality from cardiovescular disease: a review of randomized controlled trials. Progress in Cardiovescular Diseases 1986;29(3 suppl 1):99-118.

MANTON KG, POSS SS. Effects of dependency among causes of death for cause elimination life table strategies. Demography 1979;16:313-27 
MANTON KG. Changing concepts of morbidity and mortality in the elderly population. Milbank Memorial Fund Quarterly/Health and Society 1982;60:183-244.

MCCORMICK J, SKRABANEK P. Coronary heart disease is not preventable by population interventions. Lancet $1988 ; \mathbf{i} i: 839-41$.

MIETTINEN TA, hUTTUNEN JK, NAUKKARINEN $v$ et al. Multifactorial primary prevention of cardiovascular diseases in middle-aged men. JAMA 1985;254:2097-2102.

MRFIT Research Group. Mortality rates after 10.5 years for participants in the Multiple Risk Factor Intervention Trial. JAMA 1990;263:1795-1801.

MULDOON MF, MANUCK SB, METTHEWS KA. Lowering cholesterol concentrations and mortality: a quantitative review of primary prevention trials. Br Med J 1990;301:309-14.

OLIVER MF. Prevention of coronary heart disease - propaganda, promises, problems, and prospects. Circulation 1986;73:1-9.

OLSON RE. Mass intervention vs screening and selective intervention for the prevention of coronary heart disease. JAMA 1986;255:2204-7.

ROBERTS MM, ALEXANDER FE, ANDERSON TJ et al. Edinburgh trial of screening for breast cancer: mortality at seven years. Lancet 1990;335:241-6.

ROSE G, SHIPLEY M. Effects of coronary risk reduction on the pattern of mortality. Lancet $1990 ; 335: 275-7$

SALONEN JT. Did the North Karelia project reduce coronary mortality? Lancet 1987;ii:269.

STG (Dutch Steering Committee on Future Health Scenarios). Cancer in the Netherlands (2 volumes). Dordrecht (the Netherlands): Kluwer Academic Publishers, 1988.

STG. Zorgen voor geestelijke gezondheid in de toekonst (in Dutch). Utrecht (the Nether(ands): Bohn Scheltema \& Holkema, 1990.

TABAR L, FAGERBERG G, DUFFY SH, DAY NE. The Swedish two county trial of mammographic screening for breast cancer: results and calculation of benefit. J Epidemiol Community Heal th $1989 ; 43: 107-14$

TSAI SP, LEE ES, HARDY RJ. The effect of a reduction in leading causes of death: potential gains in life expectancy. Am J Public Health 1978;68:966-71.

tuOMILehto J, Geboers J, SAlonen JT, Nissinen A, KuUlasmaA K, PUSKa K. Decline in cardiovascular mortality in North Karelia and other parts of Finland. $\mathrm{Br}$ Med J 1986;293:106871.

WASSERSUG JD. Food for thought. JAMA 1988;260:3000.

WINAMER SJ, FLEHINGER BJ, BUCHALTER J, HERBERT E, SHIKE M. Declining serum cholesterol levels prior to diagnosis of colon cancer. JAMA 1990;263:2083-5.

WONG 0 . A competing-risk model based on the life table procedure in epidemiological studies. Int J Epidemiol 1977;6:153-9. 


\section{SUMMARY, DISCUSSION AND CONCLUSIONS}

\subsection{Introduction}

This chapter contains a summary of the foregoing chapters $(\S 7.2)$, a discussion of the effectiveness and efficiency of prevention programmes $(\S 7.3)$ and a methodology for establishing priorities according to the efficiency of the prevention programmes ( $\$ 7.4$ ). In view of the lack of data and the existing differences in scientific and theoretical approach, this evaluation can only be considered a step along the road to a more rational prevention policy. The conclusions will be used to assess two aspects of present policies ( $\$ 7.5$ ) and recommendations for future research will be made in $\S 7.6$.

\subsection{Summary of foregoing chapters}

The purpose of this report and the groups we hope to reach are discussed in chapter 1. As a result of international developments, a change in governmental policy also occurred in the Netherlands: more consideration for prevention within the framework of the so-called health policy. This approach, however, gives rise to many questions about the effectiveness of prevention (the so-called health targets) and about what the costs of prevention will be.

In chapter 2 , an overview is given of how health, morbidity and mortality can be assessed by means of health indicators. This assessment can be considered the first step toward establishing so-called prevention profiles: a survey of the health status of a population which provides pointers for prevention programmes. In this respect, the data presented anticipates the changes in health status achieved as a result of prevention as described in chapter 3 . In addition to mortality, its derivatives life expectancy and life years lost are discussed. As measures of the burden of disease in the population, one can use the incidence and prevalence of specific diseases and conditions, the subjective self-assessment of the state of health, the use of health care facilities, the economic consequences of morbidity and mortality and the prevalence of determinants of health, morbidity and mor- 
tality. An composite indicator based on health, morbidity and mortality is disability-free life expectancy. The use of various indicators appears to lead to differences in the rank order found for different health problems.

The preventability of health problems, the assessment of health benefits achieved by means of prevention and the use of models to calculate these benefits are discussed in chapter 3. As a theoretical exercise, the gain in life expectancy that would occur if a specific cause of death were to be entirely eliminated is calculated. As an illustration, the possibilities of preventing cardiovascular disease, cancer and genetic and congenital anomalies are considered in more detail. In addition to the gain in health through prevention, attention is focussed on the price that must be paid; in this context, the use of cost-benefit and cost-effectiveness analyses is discussed. Finally the problem of establishing priorities for prevention programmes based on their effectiveness and efficiency is considered in the light of the information available at present.

Various future developments that will influence the possibilities and desirability of prevention are described in chapter 4 . The predominant development is the continuing ageing of the population and the accompanying increase in the incidence of chronic diseases, as described in a number of scenario studies. Some technological developments will lead to new or better forms of primary and secondary prevention but the picture will continue to be dominated by the need for tertiary prevention for the ageing population.

The question of whether prevention programmes for an ageing population will cause the burden of chronic diseases to decrease more rapidly than that expected as a result of the increasing life expectancy is considered in chapter 5. Most studies come to the conclusion that the so-called compression of morbidity does not occur. On the average both the total life expectancy and the disability-free life expectancy will increase, partly due to successful prevention programmes, but the period of morbidity (predominantly the last phase of life) will be prolonged as well. Evaluation of some Dutch data also seems to lead to the same conclusion. 
Finally, the phenomenon of competing causes of death is described in chapter 6 . It appears that the partial elimination of a cause of death through prevention leads to an increased risk for other causes of death. This then partially abolishes the health benefit that was the goal of the programme. Moreover, in as far as prevention does result in a gain in life years, the risk of non-lethal health problems for the elderly (e.g. hip fractures and dementia) will increase. The extent of such a phenomenon, however, is not yet clear nor is it known how it should be incorporated into the prevention policy.

\subsection{The effectiveness and the efficiency of prevention programmes}

Is prevention better than cure? Even when prevention is technically possible, the answer to this question is: sometimes it is better, sometimes it is not, depending on the price that one must pay. For this reason, an evaluation of all effects and costs should be made for every proposed prevention programme.

What can the government offer a population - or a part of that population - that is willing to participate in all prevention programmes? Can this population or this group anticipate on the average a longer life with fewer years spent in sickness and more years in good health? This is the basic idea behind the role that governmental - as well as some private - agencies have assumed. In general the burden of proof of the value of prevention programmes rests with those who propose them. The methodology developed in this report can be used for that purpose: it can show the desirability of one prevention programme in relation to others.

As a rule only a small percentage of the total budget for health care is available for prevention: nearly $5 \%$ in the Netherlands (see table 7.1 , further explained in $\S 7.5 .2$ ) which is comparable to the 5-6\% in Great Britain (Cohen and Henderson 1988). The advantages and disadvantages of prevention programmes must be made explicit if one wants to continue to claim this percentage and especially if more facilities for prevention are requested. This applies in particular if the costs are to be covered by sectors other than health care. The more limited the means 
for prevention, the greater the need for the establishment of priorities. Pressure groups can have a considerable influence on the establishment of priorities.

Table 7.1 Expenditures for primary and secondary prevention in the Dutch health care sector, in millions of guilders (1988)

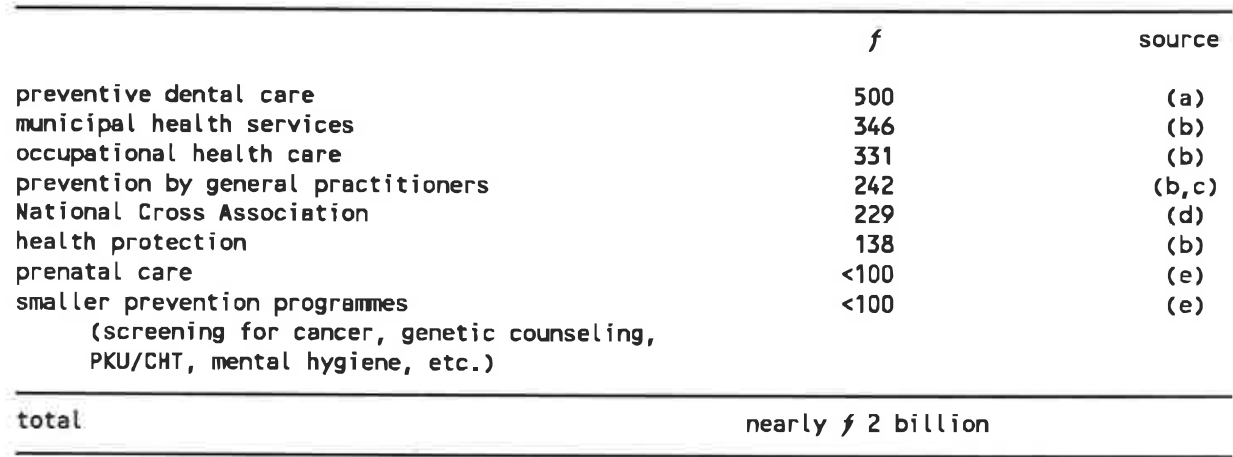

Notes

1. sources:

(a) based on: Statistisch overzicht van de behandeling gegeven door tandartsen-algemeen practicus en regionale instellingen voor jeugdtandverzorging aan ziekenfondsverzekerden (in Dutch). Zeist (the Netherlands): Comissie Tandheelkundige Stat istiek, VNZ, 1990.

(b) Financieel overzicht zorg 1990 (in Dutch). The Hague: Parliamentary document no. 21310.

(c) Bosman J, Verhaak PFM, van der Velden J. Nationale studie ven ziekten en verrichtingen in de huisartspraktijk. Deelstudie preventie (in Dutch). Utrecht (the Netherlands): NIVEL (in press).

(d) Nationale Kruisvereniging. Kruiswerk: voor zorg en voorzorg (in Dutch). Bunnik (the Netherlands): Nationale Kruisvereniging, 1989.

(e) estimates

2. The total expenditure for health care in 1988 was $\& 44.3$ billion (a), including $\mathbf{f 4 . 4}$ billion for old-age homes which can only partially be considered part of the health care sector.

3. 1 U.S.dollar = approx.f 2 (in 1988).

4. Municipal and occupational health services also perform a few tasks outside the field of primary and secondary prevention.

5. Health protection programmes consist mainly of quality control of foodstuffs and drinking water.

There is also another reason for establishing priorities within preventive care, i.e. the acceptance of the population that is presumed to participate actively in the programmes. This acceptance is limited for those programmes that require active participation; age will also play a role in this respect. Activities such as the inspection of food and automobiles can be carried out fairly unobtrusively and childhood vaccination and periodic check-ups during pregnancy are commonly 
accepted but this is not true for mass screening programmes for various diseases or changes in life style. The enthusiasm of the population could quickly melt away at the suggestion that one should stop smoking, drink less alcohol, change eating habits (fats, fibres, vitamins, salt, calories, etc.), have safe sex, exercise more, refrain from having pets, spend less time in the sun, undergo tests for cholesterol level, blood pressure, ocular pressure and early stages of cancer regularly and prevent all sorts of accidents - all at the same time! Some might even find that type of life dull, feeling more empathy for the words of the German philosopher Nietzsche (1844-1900): "Glaubt es mir: das Geheimnis um die grösste Fruchtbarkeit und den grössten Genuss vom Dasein einzuernten, heisst: gefahrlich leben!" (from: die frohliche Wissenschaft).

There are various interesting books that try to provide an insight into the effectiveness of prevention in general and numerous specific preventive measures in particular (Ciba Foundation 1985; Russell 1986; Silman and Allwright 1988; Fisher 1989).

"Setting Priorities in Prevention" emphasizes the following aspects:

- it gives a methodical overview of the various health indicators and their application in prevention;

- it attempts to present a total picture of prevention and the health benefits that can be achieved and is therefore not directed primarily at specific preventive measures against one particular disease category and the effects of such measures;

- it offers a realistic approach to prevention because it also describes the costs involved as well as adverse effects, such as an increase in chronic non-lethal diseases (decompression of morbidity) and the competition of causes of death, that may occur as a result of prevention;

- it attempts to establish a rank order for the efficiency of prevention programmes in order to facilitate a discussion of priorities;

- it provides Dutch data as a contribution to the international discussion on prevention;

- it explains the Dutch approach to the health indicator "disability-free life expectancy", the theoretical gains in life years as result of the elimination of certain diseases and the economic consequences of morbidity and mortality;

- it pinpoints those aspects characterized by a lack of knowledge. 
The effectiveness of a preventive measure is the degree to which one succeeds in achieving the desired health benefits by means of that measure, irrespective of the costs for the health care sector as well as other costs. The efficiency of the measure is the degree to which the relationship between effectiveness and costs can be considered favourable in comparison with other preventive measures. Efficiency therefore does not mean that a prevention programme leads to a saving in the expenditures of the health care sector. This is only the case in exceptional cases, for instance several vaccination programmes. In general prevention leads to higher costs for society but, in exchange, one gains health benefits. In this sense, efficiency is the best criterion for a mutual comparison of prevention programmes.

Thus, the use of safety belts in the back seat of automobiles is exceedingly ef fective as a means of preventing a small number of injuries due to accidents but is much less efficient than other prevention programmes because of the very small health benefit and the high cost of installing safety belts in all automobiles as well as the discomfort of having to use them.

Prevention programmes that benefit only a few people can sometimes be as efficient as others. Phenylketonuria is an extremely rare hereditary disease but the availability of a simple and reliable laboratory test, the easy preventability by means of a diet and the high and permanent costs once the disease occurs make the screening of hundreds of thousands of newborns an efficient method for the identification of a few cases.

On the other hand, some cases of colorectal cancer might be discovered at an early stage, when the disease could still be treated, if the population were examined annually with an endoscope, but the radical diagnostics involved as well as the high costs and low yield make this method inefficient in comparison with other screening programmes.

It is clear that the value of prevention depends on the following factors:

- it must be directed toward a major public health problem; however, for some rare diseases, the relationship between the health benefits obtained by means of prevention and the costs will turn out to be favourable;

- one or more effective preventive measures must exist;

- the preventive measures must also be efficient in relation to other measures, and this is the ultimate criterion which in fact encompasses the first two. 
On the basis of the indicators described in chapter 2 , the following health problems would appear in first instance to be suitable for prevention: cardiovascular disease, cancer, psychiatric disorders, diseases of the musculoskeletal system, dementia and accidents (in that order).

In chapter 3 it was explained that the preventability of health problems does not parallel the magnitude of these problems. In addition, as described in chapters 5 and 6 , it appears that preventive measures that are successful in themselves in the fight against cardiovascular disease and cancer can also have other undesirable consequences: decompression of morbidity and competing causes of death. On the basis of all of these facts, an attempt will be made in the following paragraph to establish priorities for prevention programmes on the grounds of their efficiency.

\subsection{Setting priorities in prevention}

\subsubsection{Methodology}

In table 7.2, a method is shown for establishing priorities for prevention programmes: the purpose is to have a comprehensive picture of the efficiency of prevention programmes by giving individual scores to each "component" of efficiency.

The scores can be numerical (e.g. 0 to 5 or - more difficult - 0 to 10) or pluses and minuses. Two examples in simplified form:

- mass screening for high cholesterol levels, followed by treatment if necessary, is a programme dealing with one of the major health problems; theoretically, prevention is quite feasible by means of changes in diet and drugs; in practice, screening and life style changes are not easily accepted by the population; the costs of screening and treatment are considerable, not only in monetary terms but also as far as "intangibles" are concerned; increasing longevity with some expansion of morbidity and/or rising cancer incidence may result from a lower serum cholesterol level in the population; all of these elements together might lead one to the conclusion that a nation-wide cholesterol programme is not a very efficient form of prevention. 
Table 7.2 Priorities in prevention: a method to establish a rank order of prevention programmes according to efficiency

\begin{tabular}{|c|c|c|c|c|c|c|}
\hline Prevention programme & $\begin{array}{l}\text { (potential) } \\
\text { size of health } \\
\text { problem }\end{array}$ & $\begin{array}{l}\text { theoretical } \\
\text { preventability } \\
\text { (= efficacy) }\end{array}$ & $\begin{array}{l}\text { practical } \\
\text { preventability } \\
(=\text { effectiveness })\end{array}$ & costs & $\begin{array}{l}\text { obst ructing } \\
\text { developments }\end{array}$ & efficiency \\
\hline \multirow{2}{*}{\multicolumn{7}{|c|}{ anti-smoking policy }} \\
\hline \multirow{2}{*}{\multicolumn{7}{|c|}{ screening for hypertension }} \\
\hline & & & & & & \\
\hline \multicolumn{7}{|l|}{ screening for breast cancer } \\
\hline \multicolumn{7}{|l|}{$\begin{array}{l}\text { screening for cervical cancer } \\
\text { anti-alcohol policy }\end{array}$} \\
\hline \multicolumn{7}{|l|}{ immunization of children } \\
\hline \multicolumn{7}{|l|}{ school heal th } \\
\hline \multicolumn{7}{|l|}{ antenatal care } \\
\hline \multirow{2}{*}{\multicolumn{7}{|c|}{$\begin{array}{l}\text { contraception } \\
\text { occupational health care }\end{array}$}} \\
\hline \multirow{2}{*}{\multicolumn{7}{|c|}{$\begin{array}{l}\text { occupational health care } \\
\text { genetic testing }\end{array}$}} \\
\hline & & & & & & \\
\hline \multicolumn{7}{|l|}{ preventive dental care } \\
\hline \multicolumn{7}{|l|}{ mental hygiene } \\
\hline \multicolumn{7}{|l|}{ traffic sofety } \\
\hline \multirow{2}{*}{\multicolumn{7}{|c|}{$\begin{array}{l}\text { safe sex } \\
\text { screening for PKU/CHT }\end{array}$}} \\
\hline & & & & & & \\
\hline \multicolumn{7}{|l|}{ nutrition policy } \\
\hline \multicolumn{7}{|l|}{ food quality control } \\
\hline \multirow{2}{*}{\multicolumn{7}{|c|}{ safe drinking water }} \\
\hline & & & & & & \\
\hline
\end{tabular}


- safe drinking water and good sewage systems are in existence everywhere in the industrialized world; therefore, relevant infectious diseases have ceased to be a major health problem; however, the potential size of the health problem is huge; theoretically and practically, preventive measures are feasible but cost a lot of money; the intangibles are negligible; because the diseases prevented occur mainly in younger age groups (and especially children), unwanted changes in the old age morbidity pattern probably would not occur; life expectancy at birth will be influenced, life expectancy at the age of 60 or 70 much less; these prevention programmes are very efficient and should not be neglected because of their success.

Table 7.2 is presented without scores. The reason for this is that we wish to illustrate the fact that the use of scores is to a certain extent subjective: determination of the various values of ten is not possible or is done differently by different people. During the "Prevention Profiles" project, the exercise led to interesting and stimulating debates.

There is little controversy about values in the first vertical column since much is known in most of the industrialized countries although the magnitude of the specific health problems can be assessed in many ways (see chapter 2). With respect to the size of a health problem one must consider not only the present size but also that in the past or the future, for example, what would happen if clean drinking water or vaccination against poliomyelitis were no longer available?

Quite a bit is also known about the theoretical preventability (second column), although this does not apply for many occupational health problems and psychiatric complaints. The practical realization (column 3 ) of the theoretical preventability, however, involves more subjective estimates, especially with respect to the participation of the population and the feasibility of the project. The preventability of health problems was discussed in chapter 3 .

As explained in chapter 3, the costs (column 4) should include not only the costs of the preventive measure itself but also possible extra costs for the health care sector (through increasing longevity and/or changes in the patterns of morbidity) as well as those costs that cannot be expressed in terms of money, such as the burden to the population, "medicalization", loss of freedom and abandonment of pleasures. As far as most preventive measures are concerned, little is known 
about the last two aspects and many different points of view exist.

The obstructing developments (column 5) are the possible increase in morbidity among the elderly and competing causes of death that could occur in the course of certain prevention programmes; see chapters 5 and 6 . Little can be said with certainty at this time.

If the scores in the first five columns are considered together, then one could attempt to arrive at a certain order of efficiency without specific weighting factors. Such a classification would in any event be better than one based on the prevailing opinions of the day, the interest of the media or the attention of pressure groups.

7.4.2 An example of a rank order of prevention programmes according to efficiency

The authors could not resist the temptation of filling in the matrix of table 7.2; the result is presented in table 7.3. It must be remembered that this exercise involves a degree of subjectivity.

We have used a score from - to +++, giving a range of 4 categories. It should be noted that as a general rule this is not sufficient to express the large differences between prevention programmes and again that we are more interested in the method here than the results. This report does not provide the evidence for most of the values given in table 7.3. A discussion of the efficiency of, for example, school and occupational health care will therefore not be carried out here.

Programmes that appear in our view to be highly efficient are the old-fashioned measures against some infectious diseases, such as the availability of clean drinking water (and sewage systems) and the vaccination of children.

Reasonably efficient programmes are the periodic examination of pregnant women, contraception, genetic testing and counseling, preventive dental care, the examination of newborns for phenylketonuria and congenital hypothyroidism and food quality control. 
Table 7.3 An example of a rank order of prevention progranmes according to efficiency

Prevention programme

anti-smoking policy

screening for cholesterol

screening for hypertension

screening for breast cance

screening for cervical cancer

anti-alcohol policy

immunization of children

school health

entenatal care

contraception

occupational health care

genetic testing

preventive dental care

mental hygiene

traffic safety

screening for PKU/CHT

nutrition policy

food qual ity control

safe drinking water

fluoridation of dr. Water

$$
\begin{aligned}
& \text { (potential) } \\
& \text { size of heal }
\end{aligned}
$$$$
\text { problem }
$$

theoretical preventabil ( $\approx$ efficacy)

+++
+++
+++
++
+
++
++
+
+
+
+
++
+
++
++
++
+
+
+
+
+
++
++
+ practical

preventability

( effectiveness) costs

developine
+
+
+
+
+
+
+
+
++
+
+
+
+
+
+
+
+
+
+
+
++
+
+

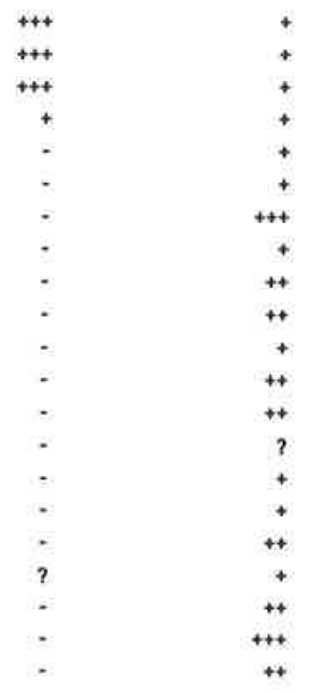

+ = low

t++ = high

$=$ absent

= unknown 
A possibly unexpected result is the fairly low efficiency of prevention programmes aimed at cardiovascular disease and cancer, school and occupational health care, further improvement of traffic safety, prevention of venereal diseases and improvements in diet. The efficiency of prevention programmes in the field of mental health cannot be evaluated at all.

The fact that the most efficient prevention programmes are aimed at health problems that are of little importance in the industrialized countries today may not be a reason for awarding them a lower priority now. In fact, they remain the most efficient and must be continued without fail. In general there will still be sufficient opportunity to continue to carry out the reasonably efficient programmes. This means that, especially for the existing programmes that do not appear to be very efficient and all newly proposed programmes (see table 4.4), a careful evaluation of all costs and effects must be made and priorities must be established. In addition to this scientific basis, political policy-making will also play an important role in the development of these programmes.

\subsection{Assessment of HFA targets and present prevention expenditure}

The nature, extent and organization of the prevention programmes listed in tables 7.1 and 7.2 developed more or less historically. The background of the prevention policy followed in the Netherlands and at the international level was described in chapter 1 . In this paragraph two aspects of that policy will be evaluated in the light of the knowledge acquired in the course of the project "Prevention Profiles".

\subsubsection{Health targets of WHO}

Many European countries approved the 38 health targets of the WHO (see Appendix). A number of these targets can be more or less quantified and they will be discussed below. The WHO and the individual member countries produce regular surveys of the results achieved (Ministry of Welfare, Health and Cultural Affairs/CBS 1988; WHO 1989). 
пг. 1: By the year 2000, the actual differences in health status between countries and between groups within countries should be reduced by at least $25 \%$, by improving the level of health of disadvantaged nations and groups.

This is immediately the most difficult one because it is not clear what health indicators and which groups within one country are involved. Are we talking about mortality, morbidity, risk factors, medical consumption, the economic consequences of disease? Does it mean differences between men and women, between geographical areas, between groups with different socioeconomic status? This target must become operational before it can be determined which specific prevention programmes are possible.

$\mathrm{nr}$. 4: By the year 2000, the average number of years that people live free from major disease and disability should be increased by at least $10 \%$.

This refers to an increase in disability-free life expectancy (see $\S 2.6$ ); trend data for the Netherlands as well as most other countries are not yet available but are needed. The various facets of this important indicator offer starting points for prevention. Further operationalization of this target is needed, especially for international comparison.

$\mathrm{nr}$ 5: By the year 2000, there should be no indigenous measles, poliomyelitis, neonatal tetanus, congenital rubella, diphtheria, congenital syphilis or indigenous maLaria in the Region.

The preventive measures for this target are clear and are being followed in most countries, including the Netherlands.

nr. 6: By the year 2000, life expectancy at birth in the Region should be at least 75 years.

This target has already been reached for females in most west and south European countries but not for males (see table 2.2). In the Netherlands and a number of other countries, the life expectancy for men and women together is already more than 75 years. The present increase in life expectancy for men and women cannot be attributed predominantly to prevention programmes. This target would seem to be secondary to nr. 4 . 
nr. 7: By the year 2000, infent mortality in the Region should be less than 20 per 1000 live births.

This target was achieved long ago in the Netherlands and other highly developed countries; furthermore, at this point a continued decrease in infant mortality may be positive in some respects but will also have adverse effects.

$\mathrm{nr}$. 8: By the year 2000, maternal mortality in the Region should be less than 15 per 100,000 live births.

This target has also already been realized in the Netherlands and all but three European countries. Although mortality due to childbirth is minimal, strict adherence to the preventive measures must be maintained.

nr. 9: By the year 2000, mortality in the Region from diseases of the circulatory system in people under 65 should be reduced by at least 15\%.

If the present trends in the Netherlands and many other European countries continue, this target will certainly be achieved, partially as a result of existing prevention programmes and curative care. In eastern Europe, however, the situation is deteriorating. This target is to a certain extent in contradiction with target 10 (see chapter 6).

$\mathrm{nr}$. 10: By the year 2000, mortality in the Region from cancer in people under 65 should be reduced by at least $15 \%$.

This target will - partially due to the favourable results of the prevention of cardiovascular disease - probably not be achieved in any country, including the Netherlands, despite existing efforts in the prevention of cancer of the lung, breast and cervix.

$\mathrm{nr}$. 11: By the year 2000, deaths from accidents in the Region should be reduced by at least $25 \%$ through an intensified effort to reduce traffic, home and occupational accidents.

As a result of present activity in the field of accident prevention, this target will be achieved in some countries, including the Netherlands, but not in others. Attention must now be focussed on the prevention of home and leisure accidents. 
$\mathrm{nr}$. 12: By the year 2000, the current rising trends in suicides and attempted suicides in the Region should be reversed.

Current trends in suicide are not unfavourable in the Netherlands but it is not clear what the preventive role of the mental health care sector has been and must be. In other European countries trends in the incidence of suicide vary widely.

$\mathrm{nr}$. 16: By 1995, in all Member states, there should be significant increases in positive health behaviour, such as balanced nutrition, non-smoking, appropriate physical activity and good stress management.

Only as far as smoking is concerned can a clear-cut statement be made about this target. The trends in this area are favourable for the Netherlands but vary in other European countries. The possibilities for prevention are known. The role of changes in diet in targets 6 and especially 4 is not clear.

$\mathrm{nr}$. 17: By 1995, in all Member states, there should be significant decreases in healthdamaging behaviour, such as overuse of alcohol and pharmaceutical products; use of illicit drugs and dangerous chemical substances; and dangerous driving and violent social behaviour.

Progress in this area varies in the European region and in the Netherlands; moreover there is often a lack of data. A number of preventive measures is known.

In conclusion it can be stated that the relationship between Dutch and international prevention policy and the WHO targets is not always entirely clear. For some targets the indicators need to be further defined, others have already been achieved or will be achieved without specific preventive measures while for others (intensification of) specific prevention programmes are indicated.

\subsubsection{The current pattern of expenditure for prevention}

In table 7.1, the expenditures for prevention within the health care sector are listed. Some highly efficient preventive measures, according to table 7.3, are therefore not included here: for instance, the responsibility for clean drinking water. Note, the costs listed in tables 7.2 and 7.3 are much broader than the purely monetary costs in table 7.1 so that comparison is somewhat lop-sided. 
Of the other highly or fairly efficient programmes, the costs of preventive dental care are striking. This can be attributed predominantly to the high costs of contacting and screening people without complaints.

Another noteworthy feature is the fact that some preventive programmes in the second and third largest sectors of Dutch preventive care, the municipal health services and occupational health care, appear to be less efficient than those in some smaller sectors. The municipal health services are responsible for cancer screening, control of infectious diseases, school health care and health education for a healthy life style.

The National Cross Association maintains consultation clinics, which are also responsible for vaccinations and sometimes also screening for PKU/CHT, for babies and pre-school children. The general practitioner takes care of contraception, screening for cervical cancer, many forms of individually directed prevention (for instance, the treatment of hypertension) and sometimes checkups during pregnancy. In the Netherlands, most checkups during pregnancy are carried out by midwives, who sometimes also do the PKU/CHT screening. Finally, separate centres have been set up for genetic testing while the inspection of foods is performed by an independent department of the Ministry of Welfare, Health and Cultural Affairs. Since the organization of prevention programmes is different in every country, the Dutch example may not be truly illustrative. On the other hand it is probably useful to evaluate the prevention programmes of the involved agencies in this way once in a while.

\subsection{Recommendations for further research}

As a rule one of the conclusions of a scientific report is that more scientific research is required. This is of course not the result that those who commissioned the report want to hear. Although we believe that this report presents considerable data suitable for policy-making, we too cannot stop ourselves from indicating where, in our opinion, knowledge is still lacking.

In the first place, there is the indicator "disability-free life expectancy". This indicator should be adapted so that the calculation and comparison of national and international trends will become possible. An improvement in the score for this indicator is after all the ultimate goal of prevention. The period of less than good health in life will consist of one or more types of limitation, each of a very 
different nature, that need further elaboration to enable us to develop more differentiated forms of prevention. It may then also become clear whether some prevention programmes can be targeted toward subgroups of the population.

The directly related phenomena "compression or decompression of morbidity" and "competing causes of death" obviously also need to be studied in more detail. In general, more attention will be directed within the health care sector toward comparison of all effects and all costs of various interventions. Various methods can be used for this purpose, for instance cost-effectiveness studies. In this way, a better approach to the establishment of priorities should become possible. Interesting areas of research in this respect are school health care, occupational health care and screening and prevention programmes for the elderly. More fundamental research is needed to discover possibilities for the prevention of osteoporosis, dementia, diseases of the musculoskeletal system, a number of less obvious conditions of the elderly, psychiatric complaints and genetic anomalies - in short, health problems that can have a serious effect on the quality of life but have not yet received sufficient attention from the standpoint of prevention. 


\section{LITERATURE}

CIBA FOUNDATION. The value of preventive medicine. Cibe Foundation Symposion 110. London: Pitman, 1985.

COHEN D, HENDERSON J. Health, prevention and economics. Oxford: Oxford University Press, 1988.

FISHER M (ed). Guide to clinical preventive services. An assessment of the effectiveness of 169 interventions. Report of the U.S. Preventive Services Task Force. Baltimore: William and Wilkins, 1989.

MINISTRY OF WELFARE, HEALTH AND CULTURAL AFFAIRS/CBS

Health for all by the year 2000; rapportage Nederland 1988 (in Dutch). Rijswijk (the Nether(ands): Ministerie van WVC, 1988.

RUSSELL LB. Is prevention better then cure? Washington: The Brookings Institution, 1986.

SILMAN AJ, ALLWRIGHT SPA (eds). Elimination or reduction of diseases? Opportunities for health service action in Europe. Oxford: Oxford Medical Publications, 1988.

WHO - Regional Office for Europe. Monitoring of the strategy for health for all by the Year 2000; part 1, the situation in the European region, 1987/1988. Copenhagen: WHO, 1989 (doc.EUR/HST/89.1). 


\section{APPENDIX - EUROPEAN TARGETS FOR HEALTH FOR ALL}

1. By the year 2000 , the actual differences in health status between countries and between groups within countries should be reduced by at least $25 \%$, by improving the level of health of disadvantaged nations and groups.

2. By the year 2000 , people should have the basic opportunity to develop and use their health potential to live socially and economically fulfilling lives.

3. By the year 2000 , disabled persons should have the physical, social and economic opportunities that allow at least for a socially and economically fulfilling and mentally creative life.

4. By the year 2000 , the average number of years that people live free from major disease and disability should be increased by at least $10 \%$.

5. By the year 2000 , there should be no indigenous measles, poliomyelitis, neonatal tetanus, congenital rubella, diphtheria, congenital syphilis or indigenous malaria in the Region.

6. By the year 2000 , life expectancy at birth in the Region should be at least 75 years.

7. By the year 2000 , infant mortality in the Region should be less than 20 per 1000 live births.

8. By the year 2000 , maternal mortality in the Region should be less than 15 per 100,000 live births.

9. By the year 2000 , mortality in the Region from diseases of the circulatory system in people under 65 should be reduced by at least $15 \%$.

10. By the year 2000 , mortality in the Region from cancer in people under 65 should be reduced by at least $15 \%$. 
11. By the year 2000, deaths from accidents in the Region should be reduced by at least $25 \%$ through an intensified effort to reduce traffic, home and occupational accidents.

12. By the year 2000, the current rising trends in suicides and attempted suicides in the Region should be reversed.

13. By 1990, national policies in all Member States should ensure that legislative, administrative and economic mechanisms provide broad intersectoral support and resources for the promotion of healthy lifestyles and ensure effective participation of the people at all levels of such policy-making.

14. By 1990, all Member States should have specific programmes which enhance the major roles of the family and other social groups in developing and supporting healthy lifestyles.

15. By 1990, educational programmes in all Member States should enhance the knowledge, motivation and skills of people to acquire and maintain health.

16. By 1995, in all Member States, there should be significant increases in positive health behaviour, such as balanced nutrition, non-smoking, appropriate physical activity and good stress management.

17. By 1995, in all Member States, there should be significant decreases in health-damaging behaviour, such as overuse of alcohol and pharmaceutical products; use of illicit drugs and dangerous chemical substances; and dangerous driving and violent social behaviour.

18. By 1990, Member States should have multisectoral policies that effectively protect the environment from health hazards, ensure community awareness and involvement, and support international efforts to curb such hazards affecting more than one country. 
19. By 1990, all Member States should have adequate machinery for the monitoring, assessment and control of environmental hazards which pose a threat to human health, including potentially toxic chemicals, radiation, harmful consumer goods and biological agents.

20. By 1990, all people of the Region should have adequate supplies of safe drinking-water, and by the year 1995 pollution of rivers, lakes and seas should no longer pose a threat to human health.

21. By 1995, all people of the Region should be effectively protected against recognized health risks from air pollution.

22. By 1990, all Member States should have significantly reduced health risks from food contamination and implemented measures to protect consumers from harmful additives.

23. By 1995, all Member States should have eliminated major known health risks associated with the disposal of hazardous wastes.

24. By the year 2000, all people of the Region should have a better opportunity of living in houses and settlements which provide a healthy and safe environment.

25. By 1995, people of the Region should be effectively protected against work-related health risks.

26. By 1990, all Member States, through effective community representation, should have developed health care systems that are based on primary health care and supported by secondary and tertiary care as outlined at the Alma-Ata conference.

27. By 1990, in all Member States, the infrastructures of the delivery systems should be organized so that resources are distributed according to need, and that services ensure physical and economic accessibility and cultural acceptability to the population. 
28. By 1990, the primary health care system of all Member States should provide a wide range of health-promotive, curative, rehabilitative and supportive services to meet the basic health needs of the population and give special attention to high-risk, vulnerable and underserved individuals and groups.

29. By 1990, in all Member States, primary health care systems should be based on cooperation and teamwork between health care personnel, individuals, families and community groups.

30. By 1990, all Member States should have mechanisms by which the services provided by all sectors relating to health are coordinated at the community level in a primary health care system.

31. By 1990, all Member States should have built effective mechanisms for assuring quality of patient care within their health care systems.

32. Before 1990, all Member States should have formulated research strategies to stimulate investigations which improve the application and expansion of knowledge needed to support their health for all developments.

33. Before 1990, all Member States should ensure that their health policies and strategies are in line with health for all principles and that their legislation and regulations make their implementation effective in all sectors of society.

34. Before 1990, Member States should have managerial processes for health development geared to the attainment of health for all, actively involving communities and all sectors relevant to health and, accordingly, ensuring preferential allocation of resources to health development priorities.

35. Before 1990, Member States should have health information systems capable of supporting their national strategies for health for all. 
36. Before 1990, in all Member States, the planning, training and use of health personnel should be in accordance with health for all policies, with emphasis on the primary health care approach.

37. Before 1990, in all Member States, education should provide personnel in sectors related to health with adequate information on the country's health for all policies and programmes and their practical application to their own sectors.

38. Before 1990, all Member States should have established a formal mechanism for the systematic assessment of the appropriate use of health technologies and of their effectiveness, efficiency, safety and acceptability, as well as reflecting national health policies and economic restraints.

Source: Targets for health for all - Targets in support of the European strategy for health for all. World Health Organization, Regional Office for Europe, Copenhagen, 1985. 


\section{ABBREVIATIONS}

$\begin{array}{ll}\text { AIDS } & =\text { Acquired Immuno Deficiency Syndrome } \\ \text { CBS } & =\text { Netherlands Central Bureau of Statistics } \\ \text { CHT } & =\text { Congenital Hypothyroidism } \\ \text { EUROCAT } & =\text { EUropean Registration Of Congenital Anomalies and Twins } \\ \text { GDP } & =\text { Gross Domestic Product } \\ \text { GNP } & =\text { Gross National Product } \\ \text { GP } & =\text { General Practitioner } \\ \text { HIV } & =\text { Human Immunodeficiency Virus } \\ \text { ICD } & =\text { International Classification of Diseases, injuries and causes of } \\ & \text { death } \\ \text { MRFIT } & =\text { Multiple Risk Factor Intervention Trial } \\ \text { NIPG } & =\text { Netherlands Institute for Preventive Health Care } \\ \text { OECD } & =\text { Organization for Economic Cooperation and Development } \\ \text { PKU } & =\text { Phenylketonuria } \\ \text { PYLL } & =\text { Potential Years of Life Lost } \\ \text { QALY } & =\text { Quality Adjusted Life Year } \\ \text { SIG } & =\text { Dutch Centre for Health Care Information } \\ \text { STG } & =\text { Dutch Steering Committee on Future Health Scenarios } \\ \text { TNO } & =\text { Netherlands Organization for Applied Scientific Research } \\ \text { UK } & =\text { United Kingdom } \\ \text { US(A) } & =\text { United States (of America) } \\ \text { WHO } & =\text { World Health Organization } \\ \text { WVC } & =\text { (Dutch Ministry of) Welfare, Health and Cultural Affairs }\end{array}$




\section{SUBJECT INDEX}

Main references are underlined

accidents: see injuries

active life expectancy: see disability-free life expectancy

adjustment 8

ageing $\underline{103}, 106,107,108$

AIDS/HIV 62

alcohol $55, \underline{69}, \underline{71}, 152$

antenatal care/screening $\underline{75}, 76,84,147,153$

arthritis: see musculoskeletal problems

attributable risk 61

avoidable mortality $\underline{65}, 67$

back pain 42,45

breast cancer $50,52,62,64, \underline{70}, 86, \underline{87}, 91,128,131$

budget (expenditures) for prevention 140,141, 143, 152

cancer/neoplasms $11,12,15,35,36,45,62, \underline{68}, 69,70,105,106,128,129,130$, $131,133,134,144,151$

cardiovascular disease $11,12,35,36,41,42,45,52,62,63,68,70,71,72,73$, $88,89,90,91,105,113,128,129,131,133,134,144,151$

cervical cancer $62, \underline{70}, 86,87, \underline{88}, 91,128,153$

cholesterol $55, \underline{71}, 72, \underline{90}, 131,132, \underline{134}, \underline{144}$

chromosome disorders/anomalies 75,76

chronic health problems/conditions/disease $9,19,53,104,107,108,113,114$, $115,124,129,135,142$

colorectal cancer $\underline{70}, 86,91,143$

communicable diseases: see infectious diseases

community trials $\underline{72}, 111, \underline{131}, 132$

competing causes of death $91,129,132,134,135,142,144,154$

compression of morbidity $91, \underline{111}, 112,122,124,125,135,144,154$

congenital diseases/anomalies/malformations $19,68, \underline{73}, 74,75,76,91,108$

congenital hypothyroidism $\underline{76}, 147,153$

congenital rubella syndrome: see rubella

congenital syphilis $\underline{75}, 76,150$ 
contraception 147,153

coronary disease: see cardiovascular disease

cost-benefit analysis $65, \underline{78}, 79,82,83,84$

cost-effectiveness analysis/study $63,65,78, \underline{79}, 82,84,86,87,88,89,90,154$

cost of illness study: see disease costing

cost of (premature) mortality/death $31,32, \underline{35}$

cost-utility analysis 78, 79

cystic fibrosis 75

decompression of morbidity: see compression of morbidity

demand for health care: see medical consumption

dementia $45,68, \underline{107}, 129,135,144,154$

demographic model 129

demographic projection 102, 103

dental caries 55,91

dental health care 147,153

determinant of health $\underline{2}, 20,21,50,55,62,71,72,75,128$

diabetes mellitus $71,105,113$

diet $\underline{69}, 70,90,132,134,149,152$

direct costs $\underline{31}, 32,33,36,85$

disability $\underline{19}, \underline{25}, 26,28, \underline{113}, 114,115,123$

disability-free life expectancy: $\underline{22}, 25,30,55,112,114,124,142,150,153$

discounting $\underline{80}, 81$

disease costing $\underline{32}, 33,36$

diseases of the circulatory system: see cardiovascular disease

diseases of the respiratory system: see respiratory diseases

distribution of morbidity and mortality 42

Down's syndrome 54, 75

duration/length of stay/hospitalization $114,115, \underline{118}, 119,120,121,122$

economic costs/evaluation/appraisal $\underline{31}, 34, \underline{78}, 80, \underline{81}, 82$

effectiveness of prevention $3, \underline{65}, \underline{140}, 142,143$

efficiency of prevention $3, \underline{65}, 90, \underline{140}, 143,147,148,149$

elderly $\underline{103}, 107,108,111,113,114,115,116,117,118, \underline{122}, 154$

elimination of a cause of death $\underline{56}, 57,58,59,60,129,130$

environmental hygiene/pollution 55,82

epidemiological projection 105 
exercise: see physical exercise

expansion of morbidity: see compression of morbidity

expenditures for prevention: see budget for prevention

fragile $\mathrm{X}$ syndrome 75

future developments 102

gains in health: see health benefit

general practitioner $\underline{19}, 20,22,86,89,115,116,117,153$

genetic diseases/anomalies $73,74,75,76,91,108,154$

genetic screening/testing $\underline{75}, 76,147$

geographic variations in morbidity and mortality $\underline{42}, 72$

greying: see ageing

handicap: see disability

health benefit/gain/profit $\underline{51}, 61,90,131,142,143$

health care technology: see technological changes

health checkup 107,131

health education $85,86,153$

health expectancy: see disability-free life expectancy

health for all $\underline{3}, 149$

health indicator $3, \underline{7}, 44,51,113,123,128,142$

health objective $\underline{3}, \underline{7}, 8,42,70,73,76, \underline{149}, 152$

health policy $\underline{2}, 4,61$

health policy model $\underline{2}, 61,62,63,64$

health profile $\underline{7}, 22,43,44$

health status $\underline{7}, 13,18,31,44,61,108,115,150$

health target: see health objective

heart disease: see cardiovascular disease

hepatitis B 84

hereditary disease: see genetic disease

HIV: see AIDS

hospital 20,22,114,115, 116, 117, 118,119,120,122

Huntington's disease 73

hypercholesterolaemia (familial) 73

hypertension 55, 64, 71, 72, 89, 113, 131, 134, 153

hypothyroidism: see congenital hypothyroidism

immunization: see vaccination 


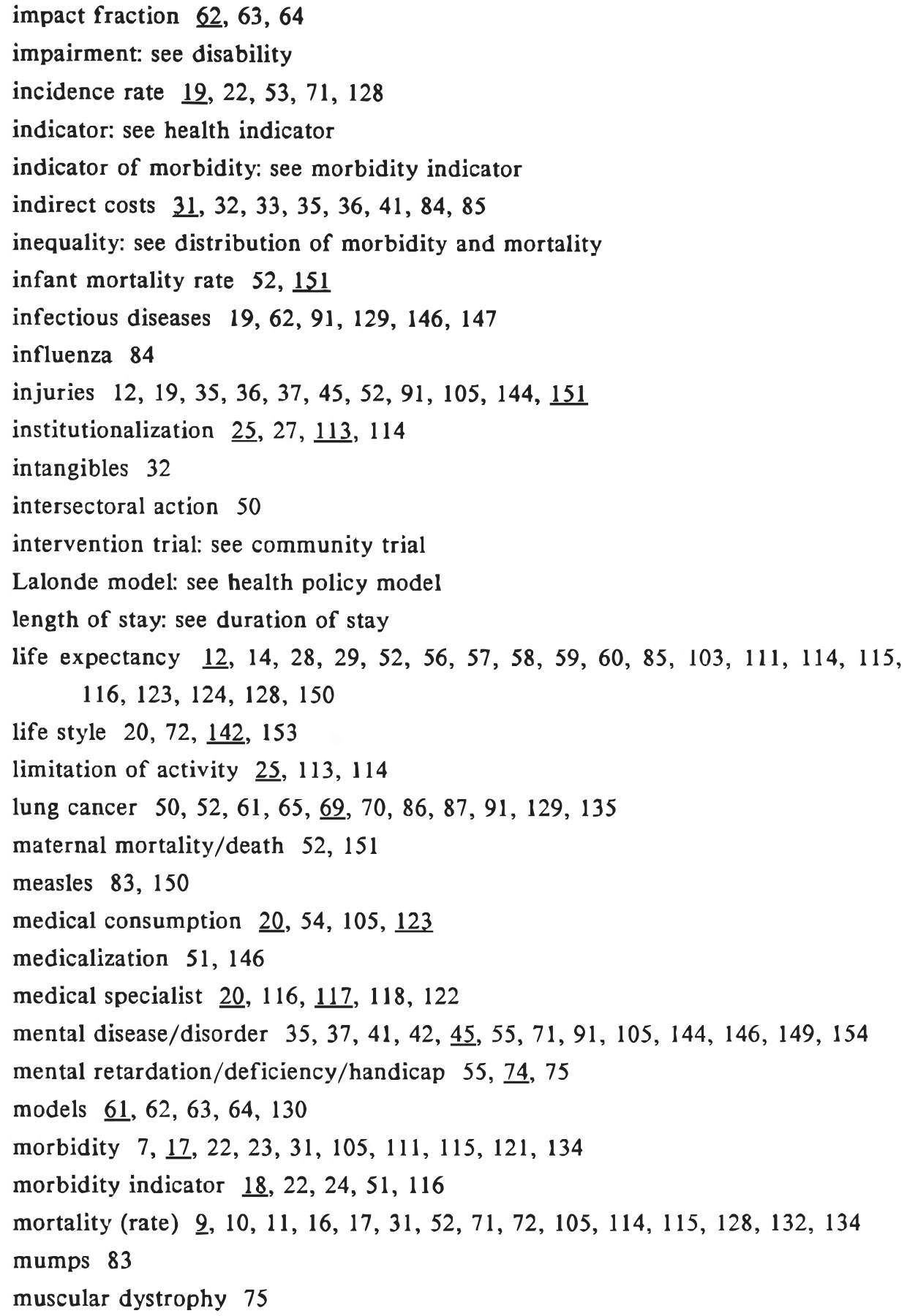


musculoskeletal problems/diseases $37,41,42,45,55,68,91,113,144,154$

myocardial infarction $\underline{71}, 72,88,116$

neoplasms: see cancer

neural tube defects 75

nursing home $22, \underline{116}, 120,121,122,123,124$

nutrition: see diet

obesity 71

occupational health care $55,146,147,149,153$

osteo-arthritis: see musculoskeletal problems

osteoporosis 154

perceived health status: see self-rated health status

phenylketonuria $\underline{76}, 91, \underline{143}, 147,153$

physical exercise/activity $\underline{21}, 71,132,152$

poliomyelitis $\underline{53}, 54, \underline{83}, 128,146,150$

population forecast: see demographic projection

positive health indicators 21

potential years of life lost $\underline{15}, 16,17$

predictive value 72

premature death $9, \underline{15}, \underline{31}, 35$

prenatal care: see antenatal care

prevalence rate $\underline{19}, 2253$

preventability $\underline{65}, 68,90,91$

prevention budget: see budget for prevention

prevention paradox 73

prevention profile $1,3,4, \underline{8}, 44,56,146$

primary prevention $\underline{50}, 72,75,81,108,131$

priorities $3,68,141, \underline{144}, 145,149$

projections 102,107

prostatic cancer 70

psychiatric illness: see mental disease

quality adjusted life year $\underline{53}, 63,80,84,89,128$

rank orders $22,24, \underline{44}, \underline{91}, 92,142, \underline{145}, 147,148$

regional health profile 43,44

registries 19,73

relative risk 61 
respiratory diseases $35,36,42,134$

restriction of activity: see limitation of activity

rheumatism: see musculoskeletal problems

risk factor: see determinant of health

risk indicator: see determinant of health

rubella $\underline{75}, 76, \underline{83}, 150$

safe sex 66,148

scenario $105,106,112,124$

school health 149,153

screening: see secondary prevention

seatbelt 21,143

secondary prevention $20, \underline{50}, 51,63,65,70,72,75,76,81,86,87,88,89,107$, $108,128,131,142$

self-rated health status $\underline{20}, 54,113, \underline{115}, 117,122,124$

serum cholesterol: see cholesterol

sexually transmitted diseases 149

sickle cell disease 75

sickness absenteeism $\underline{36}, 37,38,40,41,55$

smallpox vaccination 77,78

smoking $\underline{20}, 21,55,63,64, \underline{68}, 69,71,77, \underline{85}, 86,132,134,135,152$

socio-economic variations in morbidity and mortality 43

specialist: see medical specialist

stress: see mental disease

stroke $\underline{71}, 72,88$

subjective health status: see self-rated health status

suicide 152

surveys $\underline{19}, 25, \underline{113}, 114,115,116,117$

technological changes 107

tertiary prevention 50, 108

thalassaemia 75

tobacco: see smoking

traffic safety/accidents $15,129,149,151$

tuberculosis 65

use of health care facilities: see medical consumption

vaccination $21, \underline{82}, 83,84,85,143,147,153$ 
venereal diseases: see sexually transmitted diseases

work disability $36,39,40,41,55$

years of potential life lost: see potential years of life lost 